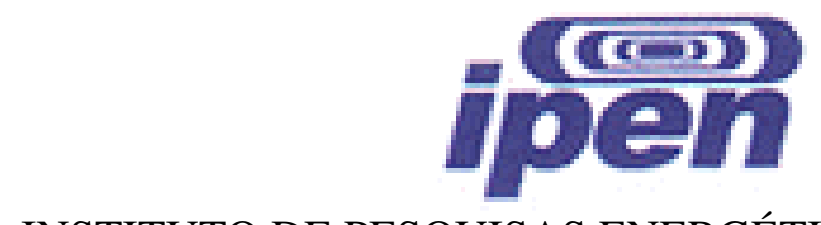

INSTITUTO DE PESQUISAS ENERGÉTICAS E NUCLEARES

Autarquia associada à Universidade de São Paulo

\title{
UTILIZAÇÃO DE REDES NEURAIS ARTIFICIAIS PARA DETERMINAR O TEMPO DE RESPOSTA DE SENSORES DE TEMPERATURA DO TIPO RTD
}

ROBERTO CARLOS DOS SANTOS

Dissertação apresentada como parte dos requisitos para obtenção do Grau de Mestre em Ciências na Área de Tecnologia Nuclear - Reatores.

Orientadora: Dra. Iraci Martinez Pereira

São Paulo

2010 
Dedico este trabalho aos meus pais, Moacir (in memoriam) e Evanilde, pelo amor, carinho e pelo total apoio à minha formação. A minha Esposa Amada e meus filhos Luís Ricardo e João Carlos pelo amor, carinho e compreensão. 


\section{AGRADECIMENTOS}

A Dra. Iraci Martinez Pereira pela orientação, amizade e pelo incentivo para a realização deste trabalho.

Ao Instituto de Pesquisas Energéticas e Nucleares IPEN - CNEN/SP pela oportunidade para o desenvolvimento deste trabalho.

Ao Centro de Engenharia Nuclear - CEN, pelo apoio com laboratórios e incentivo para o desenvolvimento deste trabalho.

A todos os meus amigos e colegas do CEN, que colaboraram direta ou indiretamente para a realização deste trabalho.

A todos os meus amigos e colegas do IPEN, que colaboraram direta ou indiretamente para a realização deste trabalho.

A minha mãe Evanilde, minha esposa Amada e aos meus filhos Luís Ricardo e João Carlos, pelas palavras de incentivo e apoio emocional durante toda esta jornada.

A minha cunhada e grande amiga Aline de Toro Mariano e a minha sogra Sra. Meire Datovo pelas palavras de apoio e incentivo.

Aos meus sobrinhos.

Aos meus irmãos Marlene, Guilhermina e Armando, pela amizade.

A toda minha família, pelo apoio direta ou indiretamente.

Aos amigos da CPG pelo apoio recebido durante todo o mestrado.

Ao meu grande amigo Capitão Agustinho de Alcântara Machado, pelos conselhos e apoio em todos os momentos. 


\title{
UTILIZAÇÃO DE REDES NEURAIS ARTIFICIAIS PARA DETERMINAR O TEMPO DE RESPOSTA DE SENSORES DE TEMPEATURA DO TIPO RTD
}

\author{
Roberto Carlos dos Santos
}

\section{RESUMO}

Em um reator nuclear PWR a temperatura do refrigerante do circuito primário e a da água de realimentação são medidas usando RTD (Resistance Temperature Detectors), ou termômetros de resistência. Estes RTDs alimentam os sistemas de controle e segurança da usina e devem, portanto, ser muito precisos e ter bom desempenho dinâmico.

O tempo de resposta dos RTDs é caracterizado por um parâmetro denominado de Constante de Tempo, definido como sendo o tempo que o sensor leva para atingir 63,2\% do seu valor final após sofrer uma variação de temperatura em forma de degrau. Este valor é determinado em laboratório, porém as condições de operação de reatores nucleares são difíceis de ser reproduzidas. O método LCSR (Loop Current Step Response), ou teste de resposta a um degrau de corrente, foi desenvolvido para medir remotamente o tempo de resposta dos RTDs. A partir desse teste, a constante de tempo do sensor é calculada através de uma transformação LCSR que envolve a determinação das constantes modais do modelo de transferência de calor. Este cálculo não é simples e requer pessoal especializado. Por este motivo, utilizou-se a metodologia de Redes Neurais Artificiais para estimar a constante de tempo do RTD a partir do LCSR. Os testes LCSR foram usados como dados de entrada da RNA; os testes de Imersão Rápida foram usados para determinar a constante de tempo dos sensores, sendo estes os valores desejados de saída da rede.

Esta metodologia foi aplicada inicialmente a dados teóricos, simulando dez sensores com diferentes valores de constante de tempo, resultando em um erro médio de aproximadamente 0,74\%. Dados experimentais de 3 diferentes RTDs foram usados para estimar a constante de tempo, resultando em um erro máximo de 3,34 \%. Os valores de constante de tempo estimados pelas RNAs foram comparados com aqueles obtidos pelo método tradicional, obtendo-se um erro médio de $18 \%$ o que mostra que as RNAs são capazes de estimar a constante de tempo de uma forma precisa. 


\title{
TIME RESPONSE OF TEMPERATURE SENSORS USING NEURAL NETWORKS
}

\author{
Roberto Carlos dos Santos
}

\begin{abstract}
In a PWR nuclear power plant, the primary coolant temperature and feedwater temperature are measured using RTDs (Resistance Temperature Detectors). These RTDs typically feed the plant's control and safety systems and must, therefore, be very accurate and have good dynamic performance.

The response time of RTDs is characterized by a single parameter called the Plunge Time Constant defined as the time it takes the sensor output to achieve 63.2 percent of its final value after a step change in temperature. Nuclear reactor service conditions are difficult to reproduce in the laboratory, and an in-situ test method called LCSR (Loop Current Step Response) test was developed to measure remotely the response time of RTDs. From this test, the time constant of the sensor is identified by means of the LCSR transformation that involves the dynamic response modal time constants determination using a nodal heat-transfer model. This calculation is not simple and requires specialized personnel. For this reason an Artificial Neural Network has been developed to predict the time constant of RTD from LCSR test transient. It eliminates the transformations involved in the LCSR application.

A series of LCSR tests on RTDs generates the response transients of the sensors, the input data of the networks. Plunge tests are used to determine the time constants of the RTDs, the desired output of the ANN, trained using these sets of input/output data.

This methodology was firstly applied to theoretical data simulating 10 RTDs with different time constant values, resulting in an average error of about $0.74 \%$. Experimental data from three different RTDs was used to predict time constant resulting in a maximum error of $3,34 \%$. The time constants values predicted from ANN were compared with those obtained from traditional way resulting in an average error of about $18 \%$ and that shows the network is able to predict accurately the sensor time constant.
\end{abstract}




\section{SUMÁRIO}

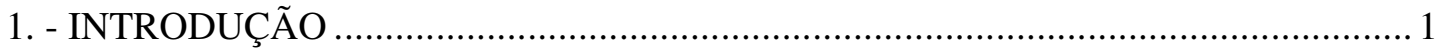

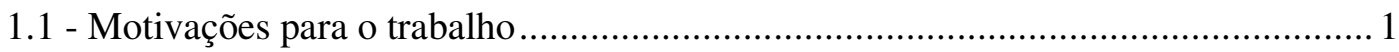

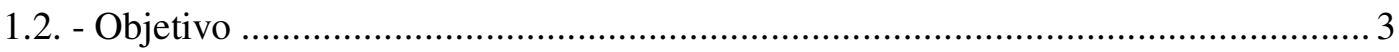

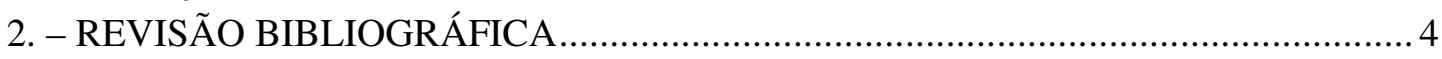

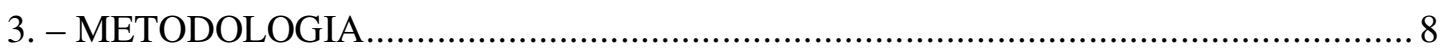

3.1. - Descrição do sensor de temperatura do tipo RTD ........................................... 9

3.2. - Teste de Imersão Rápida (Plunge Test) .......................................................... 10

3.3. - Teste de Resposta a um Degrau de Corrente (LCSR) ...................................... 12

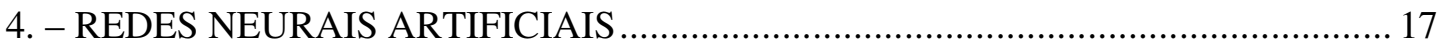

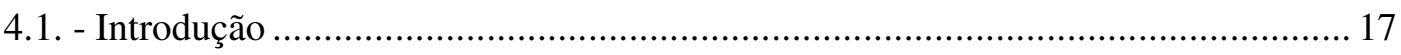

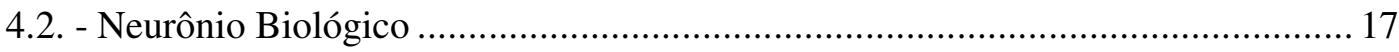

4.3. - Modelo de Neurônio Biológico..................................................................... 18

4.4. - Arquiteturas de Redes Neurais Artificiais .................................................... 23

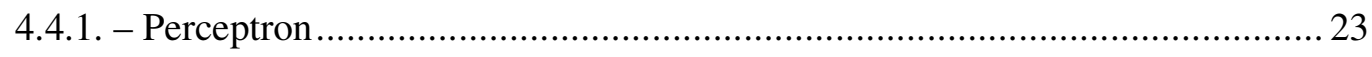

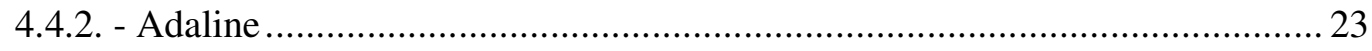

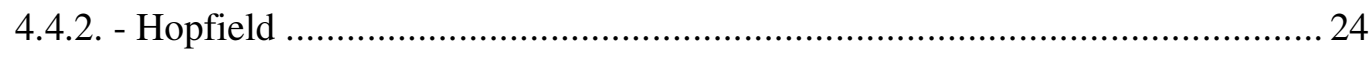

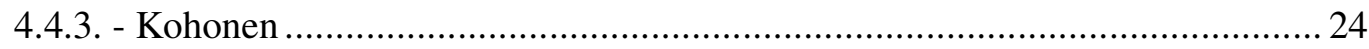

4.5. - Algoritmos de Treinamento / Aprendizado...................................................... 26

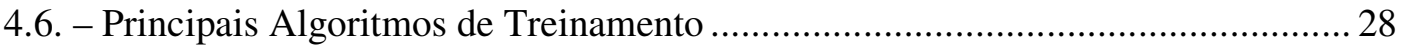

4.6.1. - Modelagem em Redes Neurais artificiais ................................................ 28

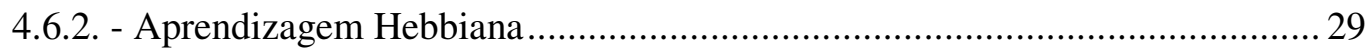

4.6.3. - Aprendizagem por Correção de Erro ........................................................... 29

4.6.4. - Regra Delta ou Método do Gradiente Descendente ....................................... 30

4.6.5. - Algoritmo de Retropropagação ................................................................ 31

5. - DESCRIÇÃO DO ARRANJO EXPERIMENTAL PARA OS TESTES DE IMERSÃO

RÁPIDA E TESTE DE RESPOSTA A UM DEGRAU DE CORRENTE (LCSR)..... 34

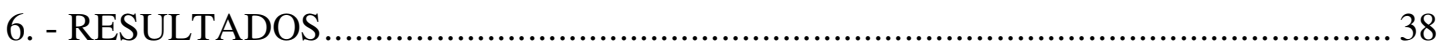

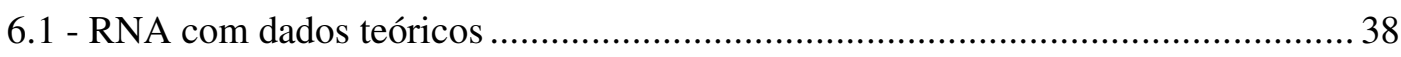

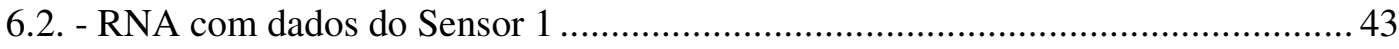

6.3. - RNA com dados normalizados do Sensor 1 .................................................. 47

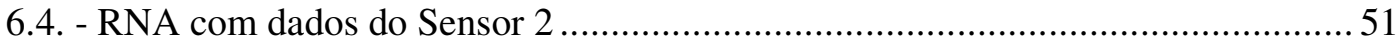

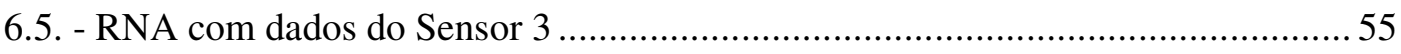

6.6. - RNA utilizando os dados dos três Sensores..........................................................59

6.7. - Comparação entre o método tradicional e o método usando RNA ........................63 63

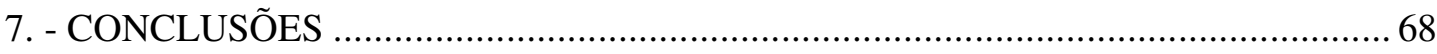

7.1 - Considerações Finais e Recomendações para trabalhos futuros ...........................69

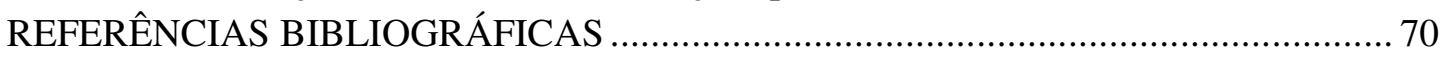




\section{LISTA DE FIGURAS}

FIGURA Título

Página

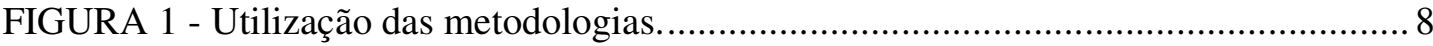

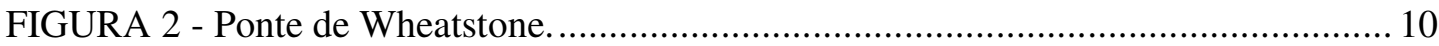

FIGURA 3 - Constante de tempo a partir do teste de imersão rápida.............................. 11

FIGURA 4 - Ponte de Wheatstone para teste LCSR de RTDs......................................... 13

FIGURA 5 - Resultado típico de um teste LCSR no Laboratório. ...................................... 14

FIGURA 6 - Resultado bom de um teste LCSR na Usina................................................ 15

FIGURA 7 - Resultado ruim de um teste LCSR na Usina.......................................... 15

FIGURA 8 - Determinação dos coeficientes da equação para o cálculo da constante de

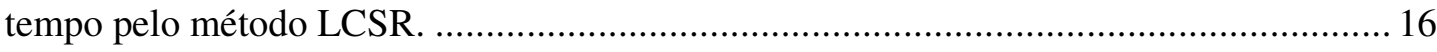

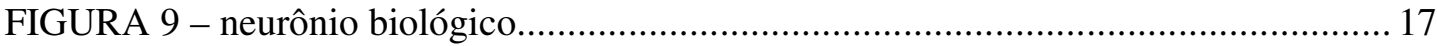

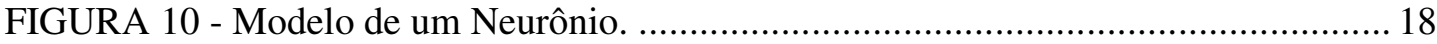

FIGURA 11 - Gráfico da Função de Limiar................................................................... 20

FIGURA 12 - Gráfico da Função Sigmóide. ....................................................................... 21

FIGURA 13 - Gráfico da Função Sigmóide - com $a$ tendendo ao infinito....................... 21

FIGURA 14 - Gráfico da Função Signun..................................................................... 22

FIGURA 15 - Gráfico da Função Tangente Hiperbólica. ................................................ 23

FIGURA 16 - Modelo Perceptron de Rosenblatt Multicamadas. ..................................... 23

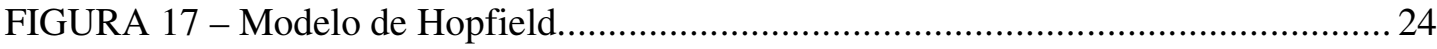

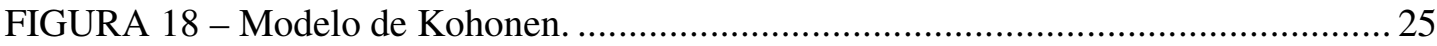

FIGURA 19 - Redes com propagação para frente de uma camada. ...................................2 25

FIGURA 20 - Redes do tipo MLP (Múltiplas camadas com propagação para frente)....... 26

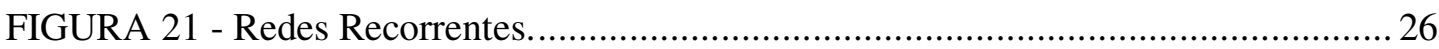

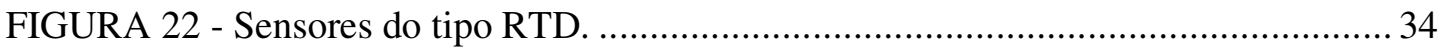

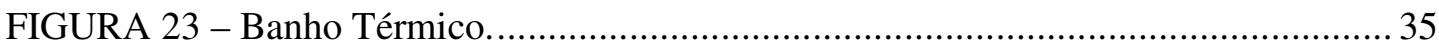

FIGURA 24 - Maleta para medida de LCSR e Teste de imersão rápida. .......................... 35

FIGURA 25 - Sistema de aquisição de dados.......................................................... 36

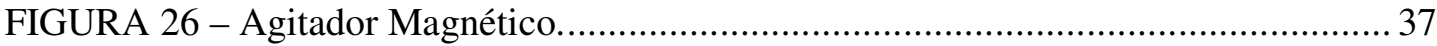

FIGURA 27 - Dados de entrada da rede Teórica. ............................................................. 40

FIGURA 28 - Dados de Saída da Rede Teórica.............................................................. 40

FIGURA 29 - Gráfico do Treinamento da Rede Teórica. ............................................... 41 
FIGURA 30 - Gráfico de comparação entre saída da rede e alvo (treinamento)............... 42

FIGURA 31 - Gráfico de comparação entre saída da rede e alvo (Teste). ........................ 42

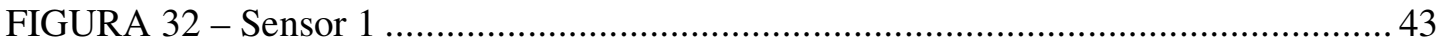

FIGURA 33 - Dados de entrada da rede do sensor 1. ................................................... 44

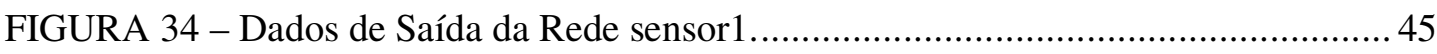

FIGURA 35 - Gráfico do Treinamento da Rede - sensor 1 .............................................. 45

FIGURA 36 - Gráfico de comparação entre saída da rede e alvo (Treinamento sensor1). 46

FIGURA 37 - Gráfico de comparação entre saída da rede e alvo (Teste sensor 1). .......... 46

FIGURA 38 - Dados de entrada da rede do sensor1. ................................................... 48

FIGURA 39 - Dados de Saída da Rede sensor 1............................................................. 49

FIGURA 40 - Gráfico do Treinamento da Rede - sensor 1 .......................................... 49

FIGURA 41 - Gráfico de comparação entre saída da rede e alvo (Treinamento sensor1). 50

FIGURA 42 - Gráfico de comparação entre saída da rede e alvo de Teste sensor 1 .........50

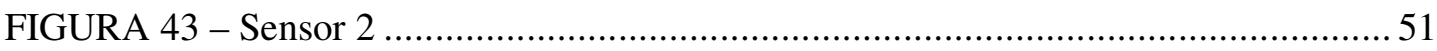

FIGURA 44 - Dados de entrada da rede do sensor2. ................................................. 52

FIGURA 45 - Dados de Saída da Rede sensor 2 ......................................................... 53

FIGURA 46 - Gráfico do Treinamento da Rede - sensor 2 …........................................ 53

FIGURA 47 - Gráfico de comparação entre saída da rede e alvo (Treinamento sensor 2).54

FIGURA 48 - Gráfico de comparação entre saída da rede e alvo (Teste sensor 2). .......... 54

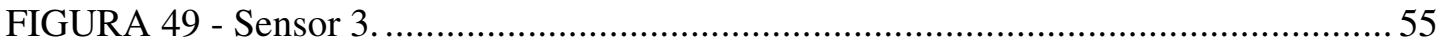

FIGURA 50 - Dados de entrada da rede do sensor 3. ..................................................... 56

FIGURA 51 - Dados de Saída da Rede sensor 3 ........................................................ 57

FIGURA 52 - Gráfico do Treinamento da Rede - sensor 3 ........................................... 58

FIGURA 53 - Gráfico de comparação entre saída da rede e alvo (Treinamento sensor 3).58

FIGURA 54 - Gráfico de comparação entre saída da rede e alvo (Teste sensor 3). .......... 59

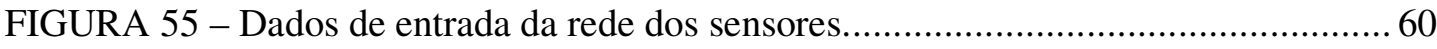

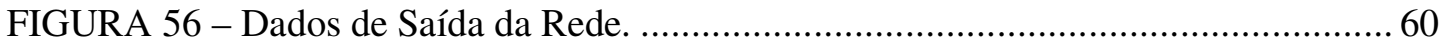

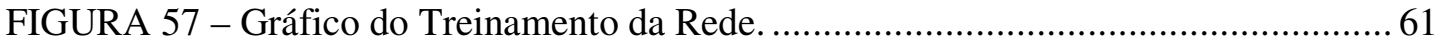

FIGURA 58 - Gráfico de comparação entre saída da rede e alvo (Treinamento sensor 3). 62

FIGURA 59 - Gráfico de comparação entre saída da rede e alvo (Teste sensor 3). .......... 62

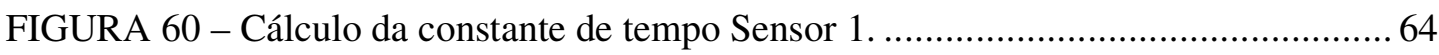

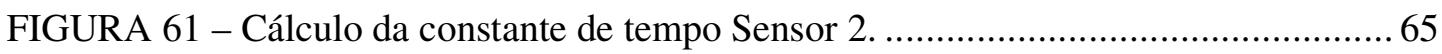

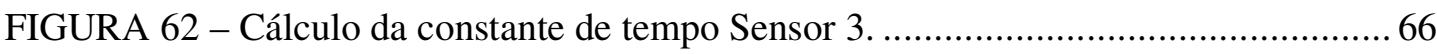

FIGURA 63 - Comparação entre as metodologias convencionais e RNAs. .......................67 


\section{LISTA DE TABELAS}

TABELA 1 - Constante de tempo de cada curva gerada ................................................. 39

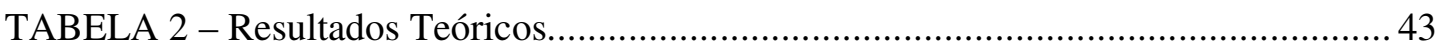

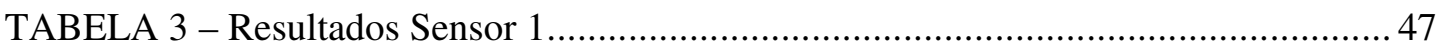

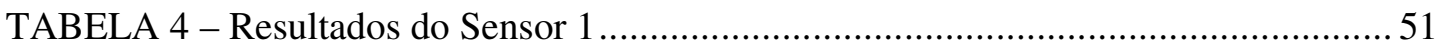

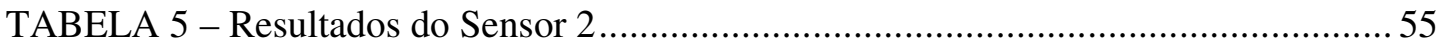

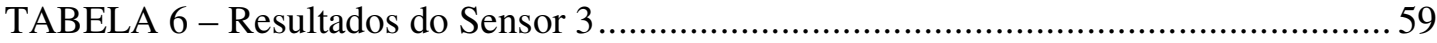

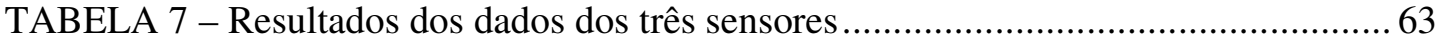

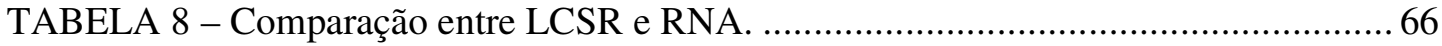




\section{1. - INTRODUÇÃO}

\section{1 - Motivações para o trabalho}

A segurança de uma usina nuclear depende, entre outros fatores, da monitoração contínua de certas variáveis consideradas críticas, como por exemplo, temperatura nas pernas quentes e frias do primário, pressão no pressurizador, nível de água no pressurizador, fluxo de nêutrons e outras. Do ponto de vista de segurança da Usina é desejável que a indicação destas variáveis seja instantânea, mas na realidade isto não ocorre, pois existe um intervalo de tempo entre o início de um transiente e o seu registro pela instrumentação de processo. Este intervalo de tempo é chamado atraso ou tempo de resposta do sistema.

A determinação do tempo de resposta de sensores de temperatura do Sistema de Proteção do Reator é um requisito de segurança que deve ser satisfeito. O NUREG 1.118 (Nuclear Regulatory Guide) da USNRC (US Nuclear Regulatory Commission) [26], [27] recomenda que sejam feitos testes periódicos a fim de se verificar se o tempo de resposta dos canais de segurança dos reatores está ou não dentro dos limites estabelecidos na análise de segurança. Recomenda também que o tempo de resposta seja medido "in-situ", ou seja, com o sensor instalado em seu local de operação normal.

Os sensores de temperatura utilizados no Sistema de Proteção do Reator são termômetros de resistência RTD (Resistance Temperature detector)

Além de satisfazer os requisitos de recomendações do órgão regulador, o teste do tempo de resposta “in-situ” é feito em RTDs pelas seguintes razões:

1. Para verificar os sensores de Usinas instalados em poços termométricos e para testar se há ar entre o sensor e a parede do poço, sujeira, e objetos estranhos nos poços.

2. Para dar provimento à manutenção preditiva, detecção de falhas incipientes, e monitoramento do envelhecimento e para estabelecer programação objetivas para a reposição de sensores.

3. Para distinguir entre problemas de sensores e problemas de cabo e conectores.

4. Para diagnosticar as anomalias de sensores ou processo.

Em quase todas as Usinas PWR de origem americana, o teste de tempo de resposta de RTD é requerido e feito uma vez a cada ciclo de operação. Para termopares, o teste de 
tempo de resposta não é mandatário, mas algumas Usinas fazem os testes para uma ou mais das razões acima citadas.

Historicamente, o tempo de resposta dos RTDs e termopares têm sido caracterizados por um parâmetro simples chamado constante de tempo de imersão (plunge) $(\tau)$. Este é definido como o tempo que a saída do sensor leva para atingir 63.2 por cento de seu valor final depois que uma mudança brusca de temperatura é imposta em sua superfície. Esta mudança em degrau é tipicamente atingida pela imersão do sensor em um tanque de água numa temperatura maior ou menor do que a do RTD. Medir $\tau$ desta forma é chamado de "plunge test" ou teste de imersão rápida.

Até 1977, os tempos de resposta dos sensores de temperatura nas Usinas de potência nuclear eram quase sempre feitos usando o teste de imersão rápida. Nos reatores nucleares, no entanto, o teste de imersão é inconveniente porque o sensor deve ser removido da tubulação do refrigerante do reator e levado ao laboratório para teste. As condições de serviço dos reatores nucleares de 150 bar (2250psig) e $300{ }^{\circ} \mathrm{C}(572 \mathrm{~F})$ são impraticáveis de reproduzir em laboratório. Portanto, todos os testes de laboratório são feitos em condições muito mais suaves, e os resultados são extrapolados paras as condições de serviço. As combinações de manipulação do sensor e extrapolação dos resultados para condições de serviço levam a erros significativos nas medidas dos tempos de resposta dos sensores, algumas vezes por um fator tão grande quanto três. Estas desvantagens do teste de imersão motivaram a indústria a encontrar melhores formas de testar o tempo de resposta de sensores de temperatura de Usinas nucleares. Como um resultado disso, os seguintes métodos foram identificados, desenvolvidos e implementados nas Usinas de potência nucleares: [11]

- Teste LCSR (Loop Current Step Response). No método LCSR, o elemento sensível é aquecido por uma corrente elétrica, e o transiente de temperatura no elemento é gravado. Deste transiente, o tempo de resposta do sensor às mudanças na temperatura externa é identificado.

- Medida do Índice de auto-aquecimento (Self Heating Test). Este método é aplicável a RTDs e é utilizado para identificar mudanças no tempo de resposta ao invés de medir o tempo de resposta. Neste método, o elemento sensível é aquecido por uma corrente elétrica variável e o aumento na resistência do RTD é medido 
como uma função da potência elétrica aplicada ao sensor. $\mathrm{O}$ resultado é referido como o "self-heating index" (SHI). Qualquer mudança significativa do SHI indica uma mudança no tempo de resposta do RTD. Portanto, o SHI pode ser acompanhado para determinar a degradação do tempo de resposta do RTD.

- Técnica de Análise de Ruído. Neste método, as flutuações naturais (ruído) que normalmente ocorrem na saída do sensor durante a operação da Usina são gravadas e analisadas para determinar o tempo de resposta do sensor. Este método é útil para testar a resposta dos RTDs, termopares e sensores de pressão. [7], [8], [9], [10], [17], [25], [30].

A determinação da constante de tempo depende de uma transformação não linear, como será descrito detalhadamente no capítulo 3.2. Por outro lado, o teste de imersão rápida fornece diretamente o valor da constante de tempo do sensor. Porém, como é um teste realizado em laboratório, dificilmente reproduz as condições originais do meio onde o sensor está instalado.

Com a finalidade de melhorar o processo de determinação da constante de tempo dos sensores RTDs, pensou-se em desenvolver uma metodologia que combinasse as informações dos testes de Imersão Rápida e LSCR. Para tanto, utilizou-se a metodologia de Redes Neurais Artificiais (RNAs).

A aplicação de Redes Neurais é uma técnica com grande potencial de exploração e que vem sendo constantemente pesquisada na atualidade. A solução de problemas por meio de RNAs é bastante atrativa, já que a forma como estes são representados internamente pela rede e o paralelismo natural inerente à arquitetura das RNAs criam a possibilidade de um desempenho superior ao dos modelos convencionais. [4]

\section{2. - Objetivo}

O objetivo deste trabalho é combinar as metodologias Loop Current Step Response e Imersão Rápida, utilizando Redes Neurais Artificiais. Os testes LCSR são usados como dados de entrada da RNA e os valores de constante de tempo dos sensores obtidos nos testes de Imersão Rápida são usados como valores desejados de saída da rede (alvo). As RNAs são treinadas com estes conjuntos de entrada e saída, obtendo-se assim uma estimativa do valor de constante de tempo do sensor de temperatura RTD. 


\section{2. - REVISÃO BIBLIOGRÁFICA}

Os avanços tecnológicos estão presentes no mundo de hoje na instrumentação, mas muitos dos problemas que encontramos hoje em dia nesta área, quanto da manutenção e calibração, dependem da tecnologia de detecção convencional que está em vigor por mais de 50 anos.

Observando estes problemas, quanto ao desempenho do sensor e a confiabilidade são necessários diversos testes da instrumentação, e surgiram novas técnicas para análise e verificação da instrumentação do processo para bons diagnósticos. Estes testes visam avaliar com exatidão o tempo de resposta, a vida residual e outras características da instrumentação instalada e oferecem meios práticos para se identificar os problemas, avaliar suas consequências, e ajudar a resolver alguns dos problemas. Os métodos in situ para os testes e a determinação do tempo de resposta dos sensores, fazem parte das medidas de segurança de uma usina nuclear.

A validação do método de LCSR foi estabelecida pelas numerosas análises laboratoriais executadas durante um período de cinco anos na década de 70 . O método de LCSR foi aprovado pela comissão reguladora nuclear de E.U. (NRC) para o teste in situ do tempo de resposta RTDs em centrais nucleares. [2].

Atualmente, a empresa, AMS (Analysis and Measurements Corporation) realiza a maioria dos testes LCSR nas usinas nucleares dos Estados Unidos [2].

No Brasil, desde 1996 o grupo de Monitoração e Diagnóstico do Centro de Engenharia Nuclear do IPEN vem realizando testes de medida de tempo de resposta dos sensores de temperatura da usina nuclear de Angra I utilizando as metodologias LCSR e Análise de Ruído.

Conforme descrito na Introdução, o trabalho proposto utiliza a metodologia de Redes Neurais Artificiais. Estas representam hoje uma poderosa ferramenta na área de pesquisa multidisciplinar. As redes neurais artificiais estão sendo utilizadas na Monitoração e na Detecção de falhas em instrumentação e processos industriais e na calibração e aferição de sensores de temperatura, como pode ser visto na descrição de alguns trabalhos citados abaixo. 
SORSA e KOIVO (1991) [34] estudaram várias arquiteturas de redes para a monitoração e detecção de falhas em um trocador de calor e em um tanque de mistura contínua. Foi utilizado um processo bem próximo do real como estudo de caso, onde existiam 14 medidas com ruído e 10 faltas típicas. Nesta aplicação, a melhor arquitetura foi a Multilayer Perceptron (MLP) que foi capaz de identificar todas as falhas.

BERNIERI et al. (1994) [3] propôs uma metodologia para detecção e isolamento de falhas em instrumentos, baseada em Redes Neurais Artificiais. Foram testados as falhas que podem ocorrer em motores de indução e os resultados obtidos foram extremamente satisfatórios.

SELIGER e FRANK (1995) [32] introduziram o conceito de Redes Neurais Artificiais na detecção de falhas e no isolamento das mesmas nos processos industriais. Foram discutidas três possibilidades diferentes de utilização das RNA'S. A primeira possibilidade seria a utilização de uma RNA ao invés de um modelo matemático, na geração de resíduos; a segunda seria o treinamento de uma RNA para realizar uma tarefa de classificação da evolução residual, e depois o isolamento da falha; a última possibilidade seria realizar a detecção em uma única etapa, onde a RNA seria treinada para detectar e isolar possíveis falhas de todas as medidas disponíveis sem a necessidade de uma geração a priori de sinais residuais intermediários.

KEYAN, DURG e NAGARAJ (1997) [15] desenvolveram um protótipo de um Sistema de Monitoração usando RNA's. O sistema possuía uma excelente interface gráfica, era extremamente amigável, e permitia que o usuário escolhesse os sinais e os parâmetros de seu interesse. Além disso, este sistema mostrava o estado ou condição dos sinais testados em condições normais e com falha. Na presença de falhas, o sistema através do uso de uma base de dados integrada, identificava a falha e indicava o progresso da falta relativa em relação à condição normal e vice-versa. Todos os sinais utilizados no desenvolvimento do sistema foram coletados de um Sistema de Aquisição de Dados de um reator nuclear.

MAKI e LOPARO (1997) [18],usaram uma rede do tipo MLP para a monitoração e detecção de falhas em processos industriais. Esta metodologia foi testada em uma estação de medidas complexas para realizar testes em um motor de indução. $\mathrm{O}$ principal aspecto 
desse estudo foi que a deteç̧ão de falhas ocorreu em regime transiente de operação do processo. Foi proposta uma RNA de dois estágios como estrutura básica do sistema de detecção. O primeiro estágio da rede detectava a direção dinâmica de cada medida; já o segundo detectava e monitorava as falhas. Este método conseguiu detectar e monitorar com grande sucesso as falhas treinadas em regime de transiente.

ABO-SHOSHA et. al. (1997) [1], usaram RNA's do tipo MLP para identificar possíveis falhas em plantas nucleares e propuseram um sistema de alarmes para auxiliar o operador na tomada de decisões.

SIMANI e FANTUZZI (2000) [33], propuseram uma metodologia de monitoração de duas fases: na primeira fase, a falha era detectada com base nos resíduos gerados por um banco de filtros Kalman; na segunda, a identificação da falha era feita através de técnicas de reconhecimento de padrões, implementadas por RNA's.

ROSSI (2001) [29], usou redes neurais do tipo MLP e Radial Basis Function (RBF) para a monitoração da potência do reator IEA-R1, visando o desenvolvimento de uma interface homem-máquina inteligente, onde a informação fosse devidamente priorizada. Os resultados obtidos após o treinamento da rede foram mostrados em uma tela de informações, juntamente com o resultado obtido através de outras formas de medida de potência, auxiliando desta maneira os operadores da instalação na eventual necessidade de calibração dos instrumentos medidores de Potência Nuclear.

SEKER et. al.(2003) [31], Estudaram o problema de utilização de RNA's para detectar possíveis anomalias, assim como os parâmetros físicos de uma Usina nuclear durante sua operação em tempo real.

MORLEY, R. E. (2003) [22], Neste trabalho foi proposto um modelo de aproximação para detecção, identificação e compensação de falha de sensores in situ. Estudos experimentais feitos em condições de laboratório demonstraram a validade e benefícios desta aproximação. Métodos passivos e ativos foram desenvolvidos e comparados sob este aspecto. Sinais obtidos dos testes LCSR em sensores de temperatura o tipo RTD foram utilizados para monitorar as condições do sensor quanto à calibração e possíveis falhas. 
TORRES Jr.(2005) [35] Estudaram aplicação de dois modelos de previsão de falhas em manutenção industrial utilizando Redes Neurais Artificiais (RNA). Os resultados obtidos neste trabalho demonstram a aplicabilidade das Redes Neurais nas previsões de falhas. Confirma-se, ainda, a habilidade das RNAs em efetuar previsão em um conjunto de dados com forte componente de não-linearidade, onde outra técnica estatística tem se mostrado menos eficaz.

TORRES, W. M. (2008) [36] Desenvolveu uma técnica de medida de nível em vasos de pressão usando sondas térmicas resfriadas internamente por um fluido e análise dos dados experimentais com Redes Neurais Artificiais (RNAs).

OLIVEIRA, M. A. A (2009) [23], Propôs o desenvolvimento de um algoritmo para auto-ajuste de sensores inteligentes a partir do uso de Redes Neurais Artificiais. Através de dados gerados em uma calibração, o algoritmo aprende a corrigir os desvios encontrados. A título de exemplo foi utilizado um sensor do tipo Pt-100. O desafio é fazer uma rede neural aprender uma curva com poucos pontos, como os gerados em uma calibração tradicional. 


\section{3. - METODOLOGIA}

O objetivo deste trabalho é combinar os testes de Imersão Rápida e LCSR utilizando a metodologia de Redes Neurais Artificiais. Portanto, os métodos empregados serão:

Teste de imersão rápida (plunge test);

Teste de Resposta a um Degrau de Corrente (LCSR);

Redes Neurais (RNA);

O diagrama de blocos a seguir (Fig.1) ilustra como estas três metodologias serão utilizadas na elaboração do trabalho.

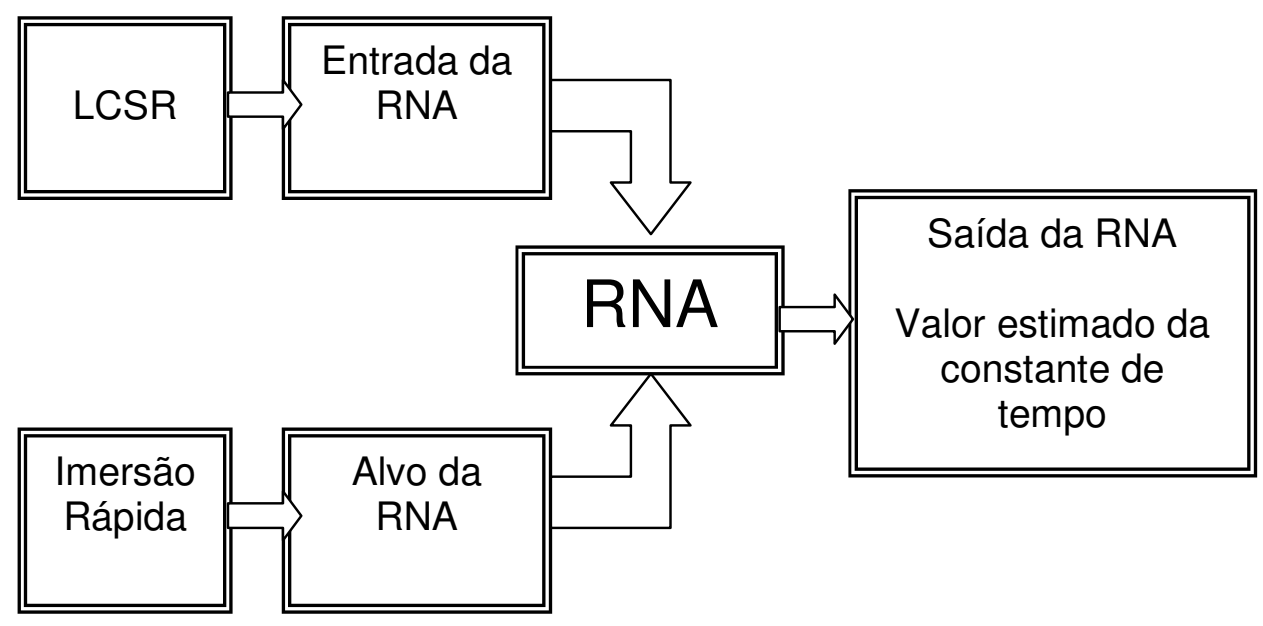

FIGURA 1 - Utilização das metodologias.

O teste de imersão rápida será utilizado para determinar o valor da constante de tempo do sensor e este valor será utilizado como saída da rede (Alvo).

Os resultados dos testes LCSR serão usados como dados de entrada da rede (camada de entrada).

A técnica de Redes Neurais Artificiais será empregada para fazer a estimativa da constante de tempo do sensor.

Primeiramente será descrito o sensor de temperatura RTD e os métodos de cada etapa serão descritos a seguir. 


\section{1. - Descrição do sensor de temperatura do tipo RTD}

Os RTDs (Resistance Temperature Detector) são dispositivos que trabalham pelo princípio físico da variação da resistividade com a variação de temperatura de alguns metais. Essas variações são quase lineares sobre uma larga escala de temperatura, e podem ser feitos pequenos o bastante para ter tempos de resposta de uma fração de segundo. Requerem uma corrente elétrica para produzir uma queda de tensão através do sensor que pode, então, ser mantido por um dispositivo de leitura externa calibrado. O metal mais utilizado na construção de RTDs ou termo-resistência é a Platina, sendo encapsulados em bulbos cerâmicos ou de vidro. Os modelos mais utilizados atualmente são: Pt- 25,5 $\Omega$, Pt$100 \Omega$, Pt-120 $\Omega$, Pt-130 $\Omega$ e Pt-500 $\Omega$, sendo que na indústria o mais conhecido e utilizado é o Pt-100 $\Omega$ (ou seja, $100 \Omega$ a $0{ }^{\circ} \mathrm{C}$ ) [21]. Normalmente o fabricante não fornece os valores de tempo de resposta dos sensores, ou quando fornece, nem sempre indica qual a técnica de medida utilizada. Isto ocorre porque a característica principal de um sensor do tipo RTD é sua precisão e não sua rapidez na resposta. Como exemplo, o tempo de resposta de sensores de temperatura de classe nuclear do tipo RTD modelo N9001 da Weed está abaixo de 5 segundos [37].

O método mais comum para medir a resistência de um RTD é usando um circuito em ponte de Wheatstone. Uma corrente elétrica de excitação passa pela ponte e pelo RTD e a tensão de saída da ponte é uma indicação da alteração da resistência do RTD. O circuito utiliza uma fonte de tensão estável, três resistores de alta precisão que tem um coeficiente de temperatura muito baixo e um amplificador de alta impedância de entrada para medir variações de resistência do RTD com as mudanças na temperatura como mostra a FIGURA 2. 


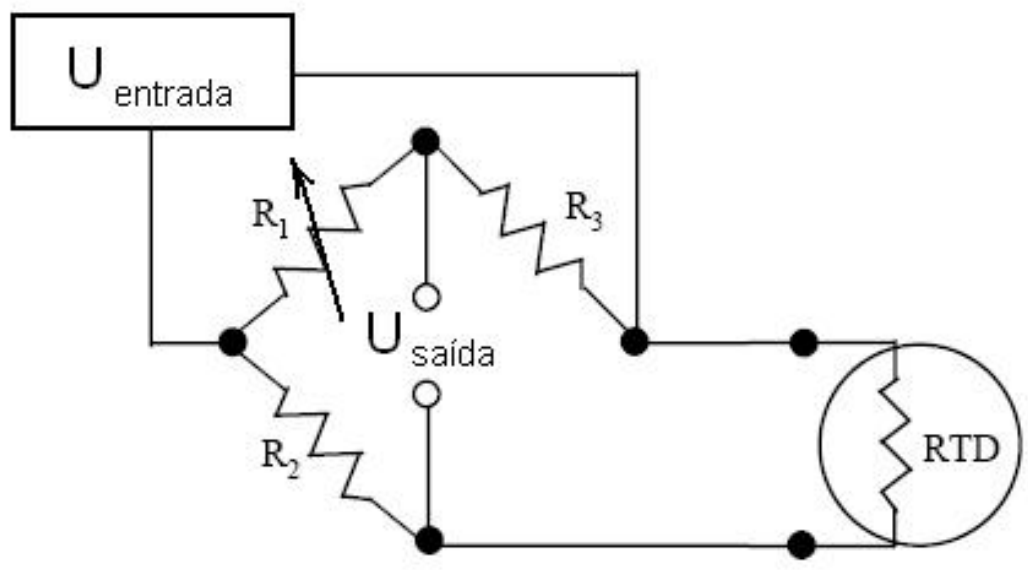

FIGURA 2 - Ponte de Wheatstone.

\section{2. - Teste de Imersão Rápida (Plunge Test)}

O teste de imersão rápida é um teste feito em laboratório que simula uma variação em degrau de temperatura do fluido onde está imerso o sensor de temperatura.

O teste consiste simplesmente em fazer a imersão rápida do sensor num fluido mantido a uma temperatura constante e monitorar sua saída até que ele atinja a temperatura de estado estacionário. Assim, o sensor passa rapidamente de uma temperatura ambiente $\mathrm{T}_{\mathrm{a}}$, para a temperatura do fluido $\mathrm{T}_{1}$, ou seja, ele sofre a ação de um degrau de temperatura. Este procedimento está ilustrado na FIGURA 3. 


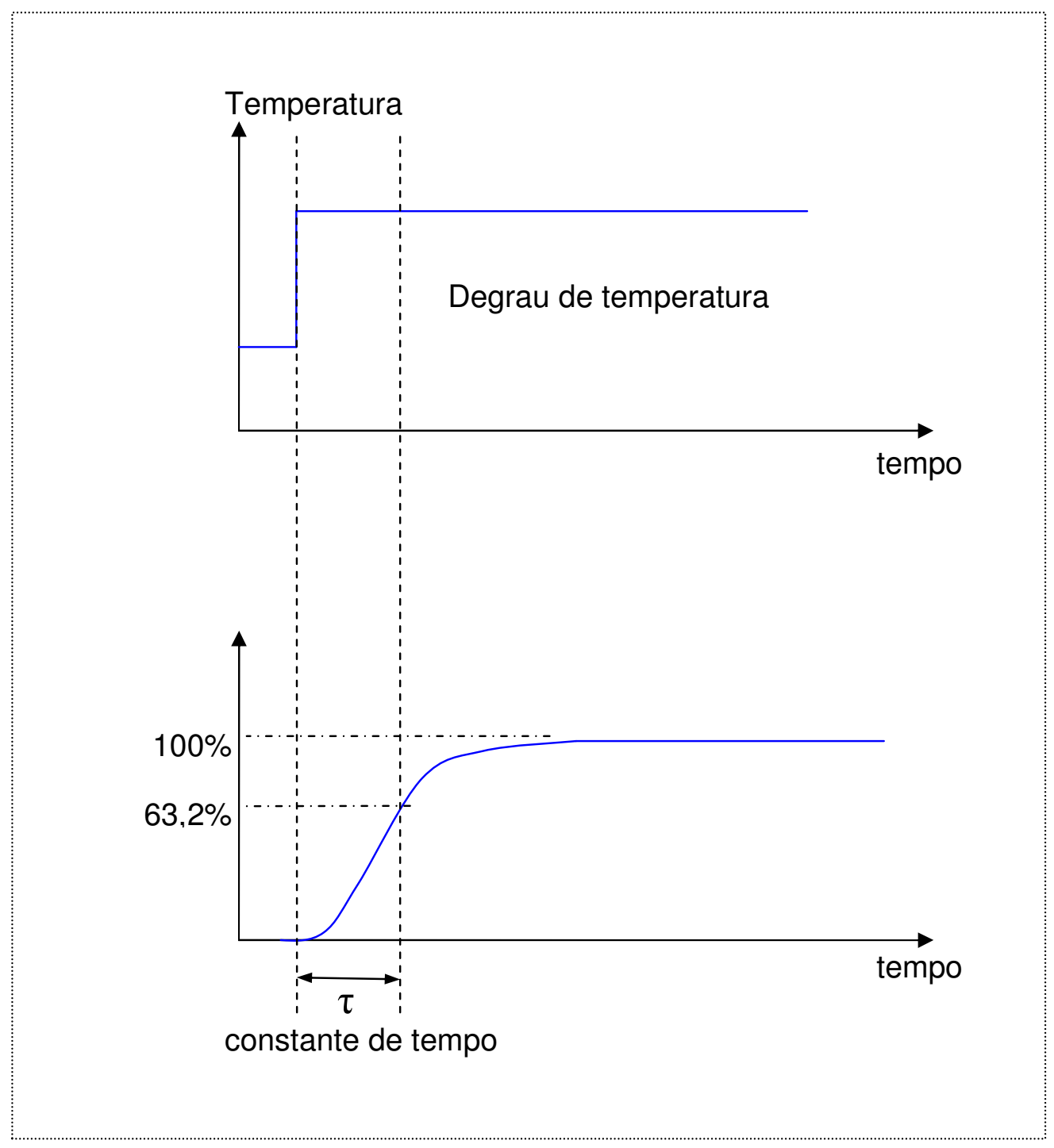

FIGURA 3 - Constante de tempo a partir do teste de imersão rápida.

Com o RTD fora da água, a ponte Wheatstone é balanceada ajustando-se o resistor variável até que a tensão de saída da ponte seja nula. Mergulhando-se o RTD no banho térmico, onde a água do banho está a uma temperatura maior que a temperatura ambiente, com isto o RTD é aquecido, variando sua resistência. Com isto ocorre um desequilíbrio da ponte tendo um aumento da tensão de saída. Esta variação de tensão é registrada num gráfico de tensão em função do tempo, durante o transiente, até que o sensor atinja o estado de equilíbrio térmico.

A constante de tempo é obtida diretamente do teste de imersão rápida e consiste no tempo necessário para a resposta atingir $63,2 \%$ do seu valor final. [6] 


\section{3. - Teste de Resposta a um Degrau de Corrente (LCSR)}

O método LCSR foi desenvolvido para medir remotamente o tempo de resposta de RTDs enquanto o sensor está instalado em processo e operando. O teste consiste em injetar uma corrente elétrica no sensor e armazenar os dados do transiente até que o processo atinja novamente o estado estacionário. A corrente causa o aquecimento por efeito Joule no sensor e resulta em um transiente de temperatura dentro do sensor. O gráfico no tempo (figura 5), tanto do aquecimento enquanto a corrente é aplicada, ou do resfriamento depois que a corrente é retirada, é gravado durante o teste de LCSR. Deste gráfico, o tempo de resposta do sensor é obtido por meio de uma transformação LCSR.

A transformação LCSR foi desenvolvida nos anos 70 pelo professor T. W. Kerlin na Universidade do Tennessee onde foi mostrado que a variação de temperatura pode ser representada pela equação a seguir: [14]

$$
T(t)=A_{0}+A_{1} e^{-t / \tau_{1}}+A_{2} e^{-t / \tau_{2}}+\ldots+A_{n} e^{-t / \tau_{n}}
$$

Onde $T(t)$ representa o transiente LCSR, e $\tau_{1}, \tau_{2, \ldots} \quad \tau_{\mathrm{n}}$ são referenciados como constantes de tempo modais. Estas constantes de tempo modais estão relacionadas com o tempo de resposta do sensor $(\tau)$ através da seguinte equação:

$$
\tau=\tau_{1}\left[1-\ln \left(1-\frac{\tau_{2}}{\tau_{1}}\right)-\ln \left(1-\frac{\tau_{3}}{\tau_{1}}\right)-\ldots-\ln \left(1-\frac{\tau_{n}}{\tau_{1}}\right)\right]
$$

Portanto, o procedimento para a determinação da constante de tempo do sensor de temperatura a partir do teste de LCSR é o seguinte:

1. Realizar o teste LCSR e armazenar os resultados do transiente;

2. Ajustar os dados do transiente à equação (1), identificando os valores de $\tau_{1,} \tau_{2, \ldots} \tau_{\mathrm{n}}$.

3. Substituir os valores de $\tau_{1}, \tau_{2, \ldots}$. $\tau_{\mathrm{n}}$ na equação (2) e calcular a constante de tempo $\tau$

Este simples procedimento pode normalmente resultar na determinação da constante de tempo do sensor com boa precisão desde que: 
1. O transiente LCSR seja suave o suficiente para ser facilmente ajustado à equação 1;

2. As constantes de tempo modais sejam identificadas com precisão e;

3. As suposições de transferência de calor para a transformação LCSR sejam satisfeitas para o sensor que está sendo testado [14].

O teste de LCSR leva em conta todos os efeitos da instalação e as condições do processo no tempo de resposta.

Para os RTDs, uma ponte de Wheatstone é utilizada para fazer o teste de LCSR como mostra a FIGURA 4. Inicialmente com a chave aberta, a ponte é balanceada com 1 ou $2 \mathrm{~mA}$ de corrente DC ajustando-se o valor do resistor variável e passando através do RTD (chave aberta). Então, a corrente é alterada para "alta" com cerca de 30 a $50 \mathrm{~mA}$ (chave fechada). Isto ocasiona o aquecimento gradual do elemento sensível do RTD que se estabiliza numa temperatura acima da ambiente. $\mathrm{O}$ valor da subida de temperatura no RTD depende da magnitude da corrente de aquecimento utilizada e da taxa de transferência de calor entre o RTD e o meio que o cerca. Tipicamente, o RTD aquece cerca de $5{ }^{\circ} \mathrm{C}$ até 15 ${ }^{\circ} \mathrm{C}$ durante o teste de LCSR.

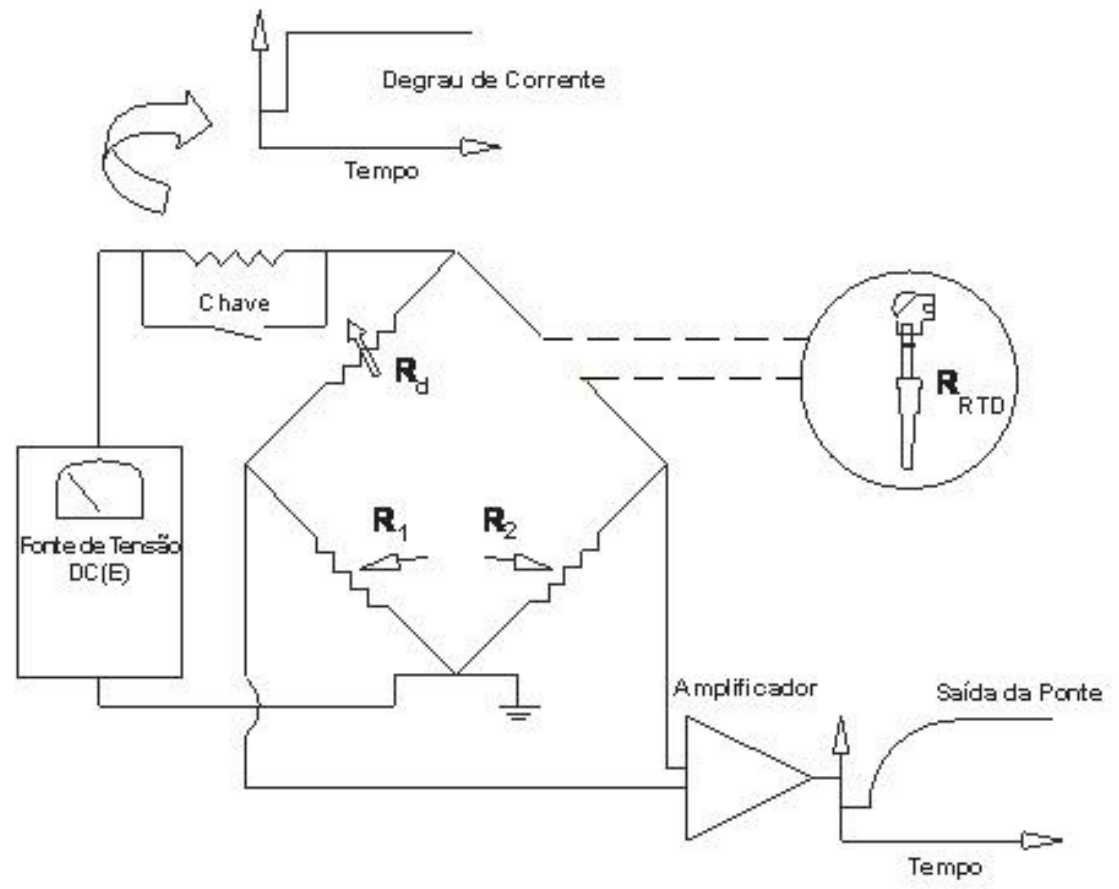

FIGURA 4 - Ponte de Wheatstone para teste LCSR de RTDs.

O teste de LCSR feito em laboratório tem um bom comportamento, pois é realizado em ambiente controlado, sendo que um teste real realizado em um reator nuclear pode vir a 
apresentar ruídos indesejáveis por várias situações, como umidade na caixa de junção, ventilação próxima ao sensor, interferência de outros instrumentos, etc. Um sinal típico de um teste realizado em laboratório é mostrado na FIGURA 5. Nas FIGURAS 6 e 7 têm-se sinais de testes realizados em uma usina.

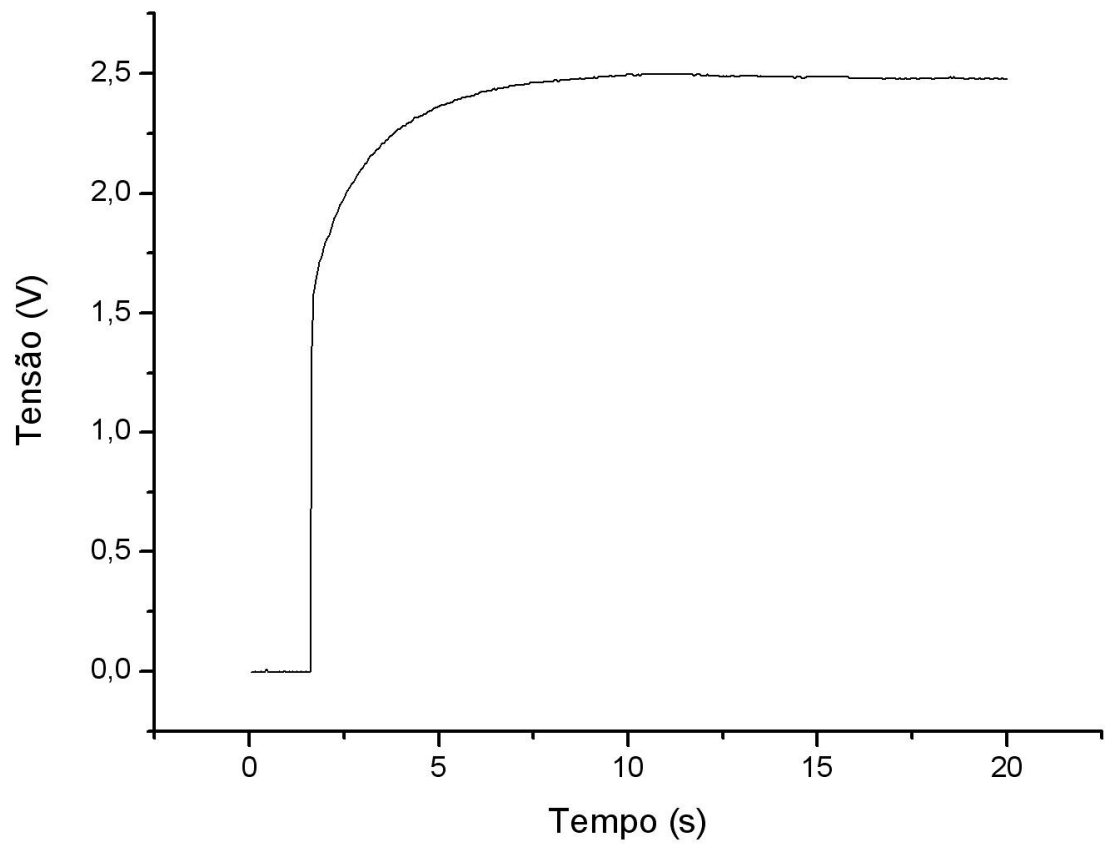

FIGURA 5 - Resultado típico de um teste LCSR no Laboratório. 


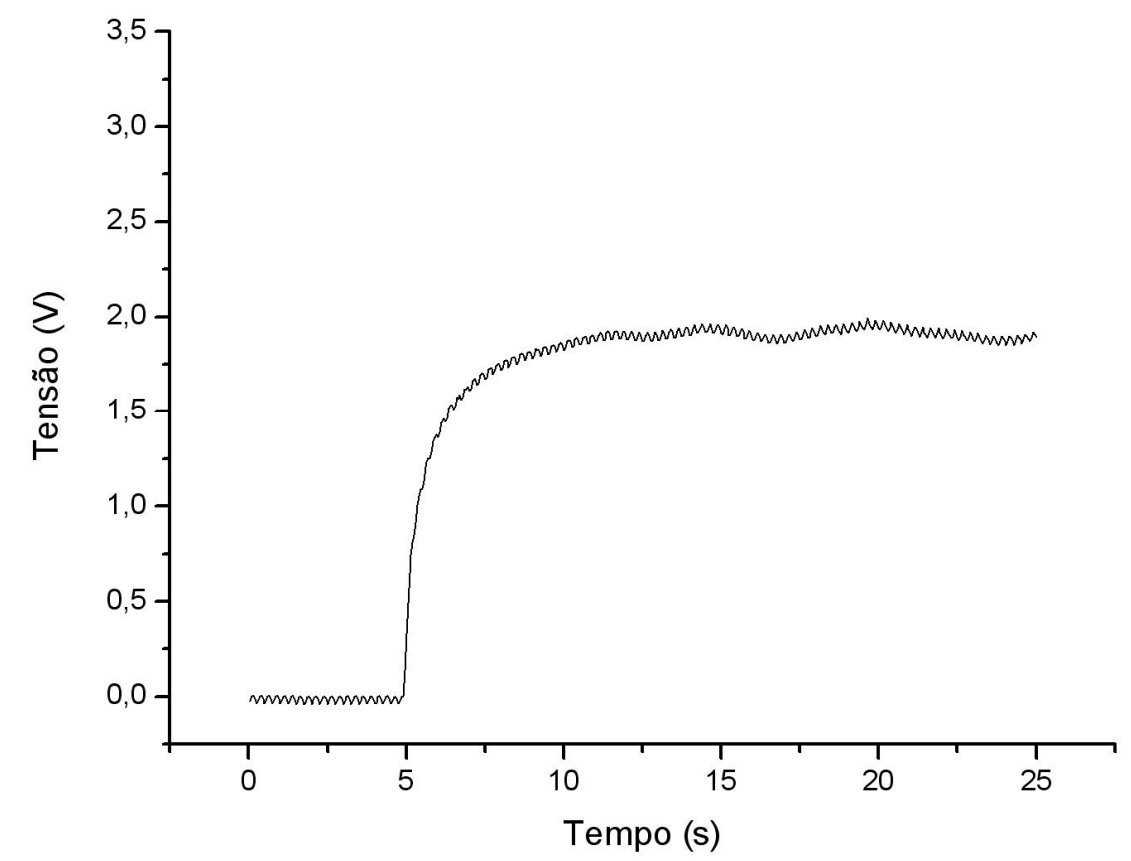

FIGURA 6 - Resultado bom de um teste LCSR na Usina.

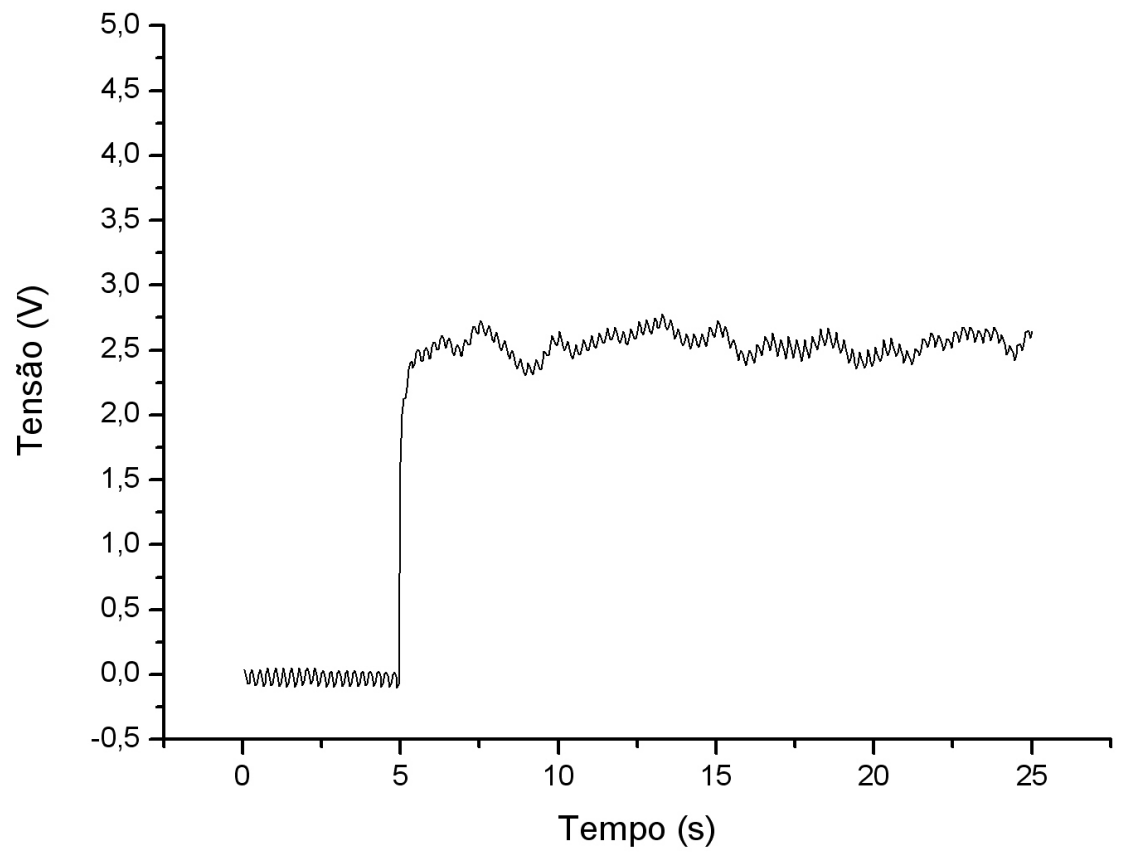

FIGURA 7 - Resultado ruim de um teste LCSR na Usina.

Na FIGURA 8 tem-se um resultado típico de LCSR. Utiliza-se o programa Origin [24] para ajustar esta curva, determinando-se os valores dos coeficientes $A_{i}$ e $\tau_{i}$ de acordo 
com a equação 1 . O valor da constante de tempo do sensor será então determinado pela equação 2.

No exemplo mostrado tem-se um ajuste considerando 2 termos exponenciais, ou seja:

$$
T(t)=A_{1} e^{\left(-x / t_{1}\right)}+A_{2} e^{\left(-x / t_{2}\right)}
$$

e os valores de t 1 e t 2 são:

$\mathrm{t}_{1}=0.07453$ e $\mathrm{t}_{2}=0,42308$

e portanto

$\tau=0,505$ segundos

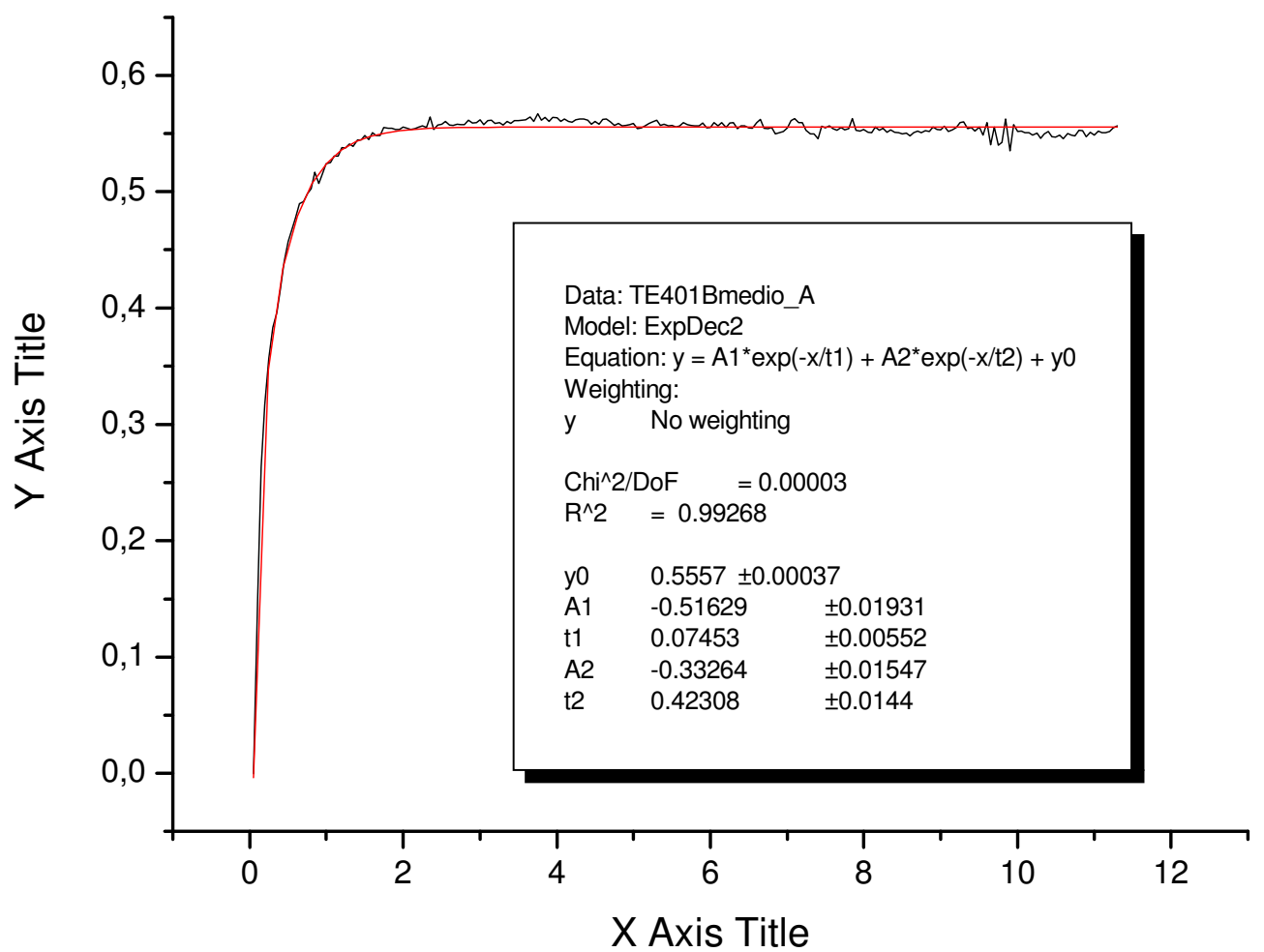

FIGURA 8 - Determinação dos coeficientes da equação para o cálculo da constante de tempo pelo método LCSR. 


\section{4. - REDES NEURAIS ARTIFICIAIS}

\section{1. - Introdução}

As redes de neurônios artificiais são sistemas de computação adaptativos inspirados nas características de processamento de informação encontradas nos neurônios reais (biológicos) e nas características de suas interconexões. São sistemas de computação massivamente paralelos que podem ser implementados tanto em hardware quanto em software, sendo que os elementos de processamento individualmente têm capacidades relativamente limitadas. Tais elementos de processamento básicos são os chamados neurônios artificiais que imitam de alguma forma o processamento de informação realizado por um neurônio biológico, e quando utilizados em conjunto e interagindo uns com os outros, compõem o que se denomina uma rede neural. Outra denominação típica para os elementos de processamento das redes neurais é a expressão nós de processamento, ou nós da rede neural. [28]

\section{2. - Neurônio Biológico}

O sistema nervoso humano é formado por um conjunto extremamente complexo de células, os neurônios. Eles têm um papel essencial na determinação do funcionamento e comportamento do corpo humano e do raciocínio. Os neurônios são formados pelos dendritos, que são um conjunto de terminais de entrada, pelo corpo central, e pelos axônios que são longos terminais de saída como visto na FIGURA 9.

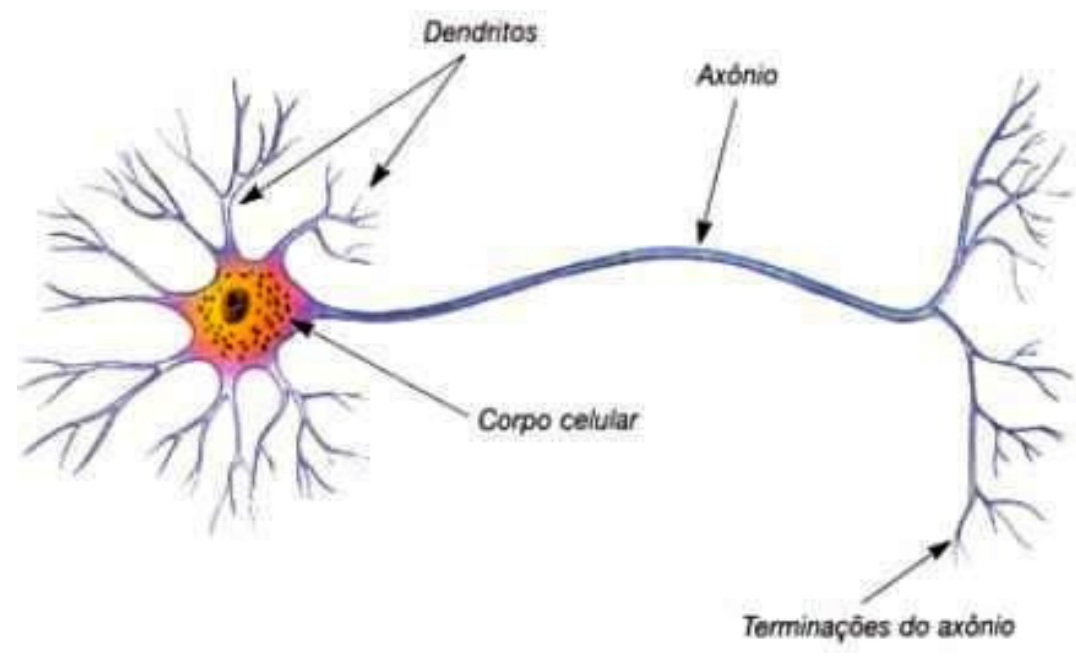

FIGURA 9 - neurônio biológico. 
Os neurônios se comunicam através de sinapses. Sinapse é a região onde dois neurônios entram em contato e através da qual os impulsos nervosos são transmitidos entre eles. Os impulsos recebidos por um neurônio A, em um determinado momento, são processados, e atingindo um dado limiar de ação, o neurônio A dispara, produzindo uma substância neurotransmissora que flui do corpo celular para o axônio, que pode estar conectado a um dendrito de outro neurônio B. O neurotransmissor pode diminuir ou aumentar a polaridade da membrana pós-sináptica, inibindo ou excitando a geração dos pulsos no neurônio B. Este processo depende de vários fatores, como a geometria da sinapse e o tipo de neurotransmissor.

Em média, cada neurônio forma entre mil e dez mil sinapses. O cérebro humano possui cerca de $10^{11}$ neurônios, e o número de sinapses é de mais de $10^{14}$, possibilitando a formação de redes muito complexas.

\section{3. - Modelo de Neurônio Biológico}

Em 1943, Warren McCulloch, juntamente com o estatístico Walter Pitts, propuseram o primeiro modelo artificial. O neurônio de $\mathrm{McCulloch}$ é um dispositivo binário, que segue a lógica da FIGURA 10. Sua saída poderia ser pulso ou não pulso, e as suas várias entradas tinham um ganho arbitrário e poderiam ser excitatórias ou inibitórias [20].

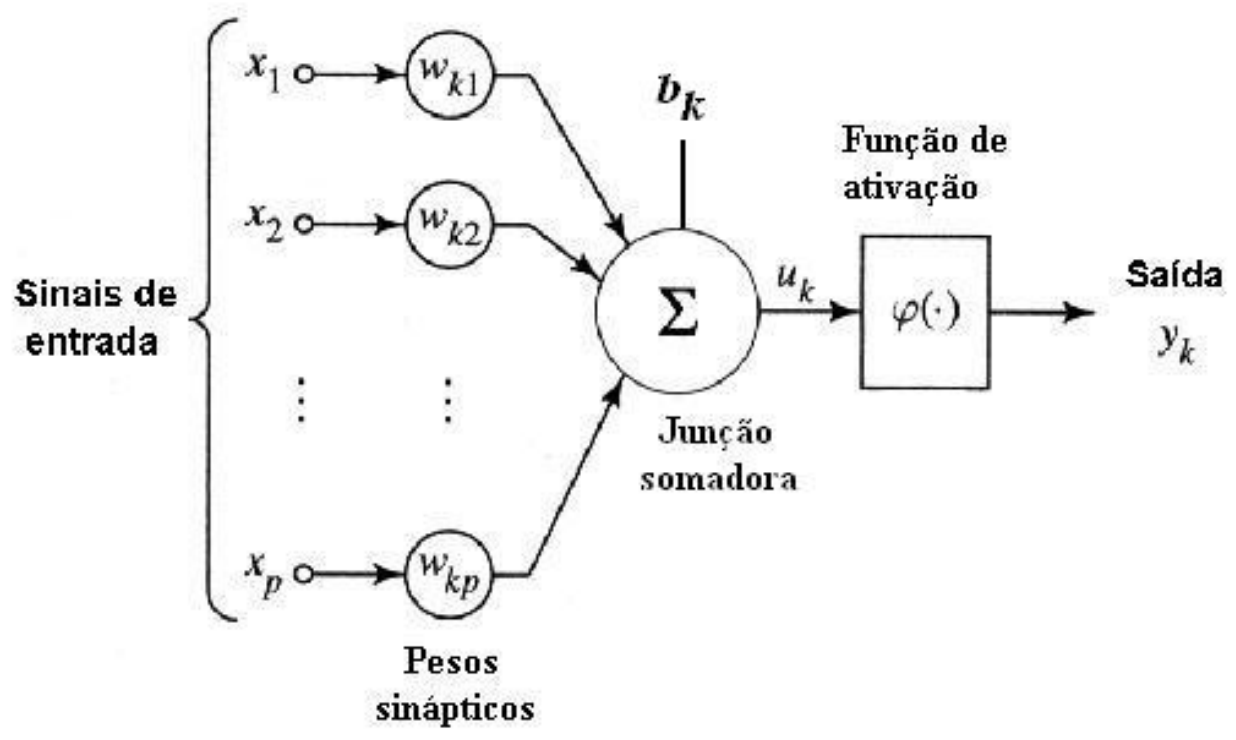

FIGURA 10 - Modelo de um Neurônio. 
As entradas do neurônio correspondem ao vetor de entrada:

$$
\mathrm{X}=\left[\mathrm{x}_{1}, \mathrm{x}_{2}, . . \mathrm{x}_{\mathrm{p}}\right]^{\mathrm{T}}
$$

Para cada uma das entradas $\mathrm{x}_{\mathrm{i}}$, há um peso correspondente $\mathrm{w}_{\mathrm{i}}$, onde os estímulos de entrada são multiplicados pelos respectivos pesos de cada ligação, podendo gerar um sinal positivo (excitatório) ou negativo (inibitório).

A saída do neurônio é definida pelo seu valor de ativação calculado da seguinte forma:

$$
v_{j}=\sum_{j=1}^{m} w_{j i} x_{i}+b_{j}
$$

Onde:

$v$ - é o valor de ativação do neurônio $k$;

$\Sigma$ - somatório dos sinais produzidos pelo produto entre pesos sinápticos e as entradas fornecidas ao neurônio.

$w$ - são os pesos das conexões do neurônio $k$;

$x$ - é o valor de cada um dos $m$ estímulos que chegam ao neurônio $k$;

$b$ - é o valor do bias que será somado ao valor do combinador linear para compor o valor de ativação.

Função de Ativação: Fornece o valor da saída de um neurônio.

A saída y do neurônio, chamada de saída de ativação, é obtida pela aplicação de uma função $\mathrm{f}$ à saída linear $v$, indicada por $\mathrm{y}=\mathrm{f}(v)$. A função $\mathrm{f}$ é chamada de função de ativação e pode assumir várias formas, geralmente não-lineares.

As funções de ativação mais utilizadas são:

- Função Limiar (Degrau): Utilizada no modelo de McCulloch e Pitts, a função limiar modela a característica 0 ou 1 deste neurônio. 
É expressa da seguinte forma:

$$
f(v)=\left\{\begin{array}{l}
1 \text { se } v \geq 0 \\
0 \text { se } v<0
\end{array}\right.
$$

Nos neurônios construídos com essa função, a saída y será igual a 0 , caso o valor de ativação $v$ seja negativo e 1 nos casos em que o valor de ativação seja positivo.

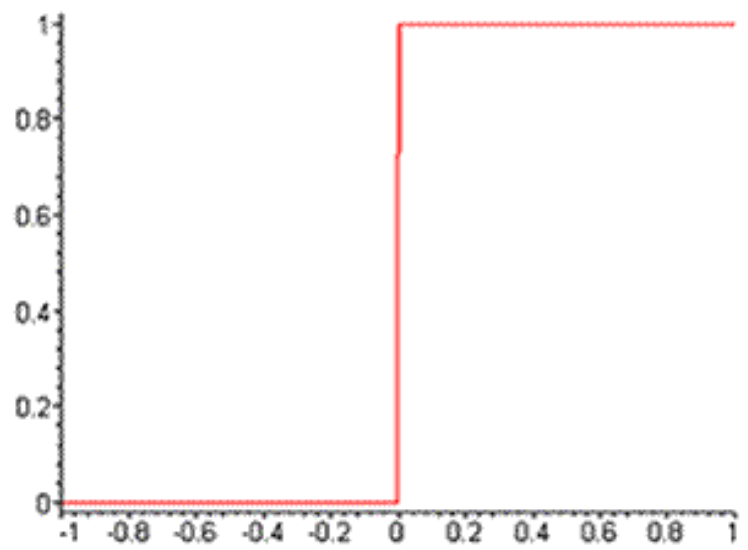

FIGURA 11 - Gráfico da Função de Limiar.

Devemos lembrar que o valor de ativação (v) é composto pelo integrador $(\Sigma)$ linear e pelo bias:

- Função Sigmóide: Esta função, ao contrário da função limiar, pode assumir todos os valores entre 0 e 1 . A representação mais utilizada para esta função é a função logística, definida por:

$$
f(v)=\frac{1}{1+e^{(-a v)}}
$$

Onde a é o parâmetro de inclinação da função sigmóide e v é o valor de ativação do neurônio. 


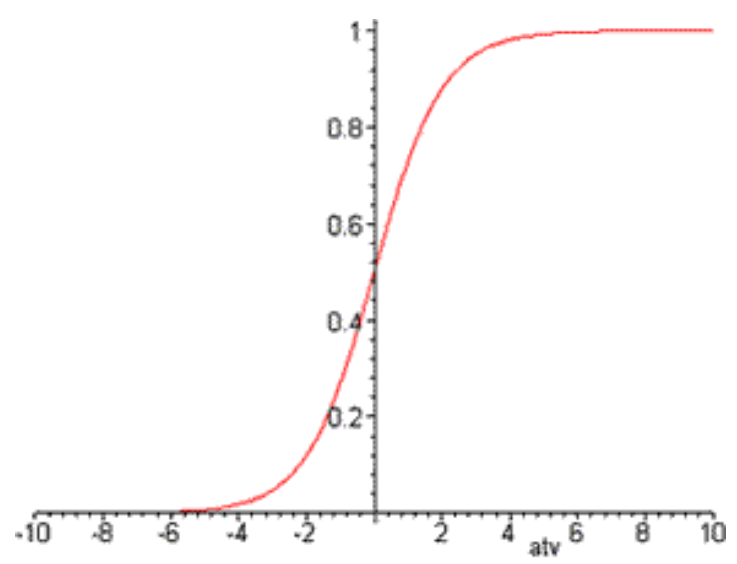

FIGURA 12 - Gráfico da Função Sigmóide.

Quando aumentamos o valor do parâmetro $a$, tendendo-o ao infinito, esta função comportase como uma função de limiar, como mostrado no gráfico a baixo:

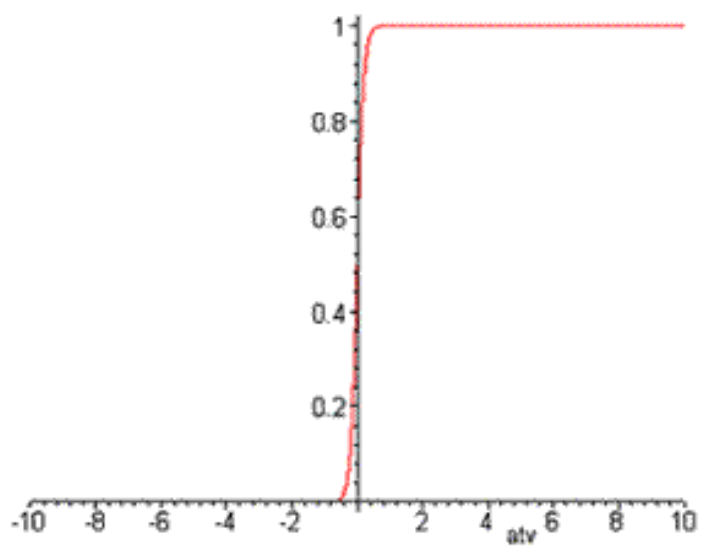

FIGURA 13 - Gráfico da Função Sigmóide - $\operatorname{com} \boldsymbol{a}$ tendendo ao infinito.

Pode ser necessário, porém, que a função de ativação assuma valores entre 1 e -1, esta característica traz benefícios analíticos. Para obtermos tal intervalo de valores utilizamos as Funções Signum, no caso da Função de Limiar, e a Função Tangente Hiperbólica, no caso da Função Sigmóide.

- Função Signum: Esta função apresenta as mesmas características da função de limiar, porém está limitada entre 1 e -1. É representada por:

$$
f(v)=b \frac{v}{|v|} \text { para } v \neq 0
$$


Onde:

$\boldsymbol{b}$ são os limites inferiores e superiores ( $b=1$ no gráfico);

$v$ é o valor de ativação da unidade.

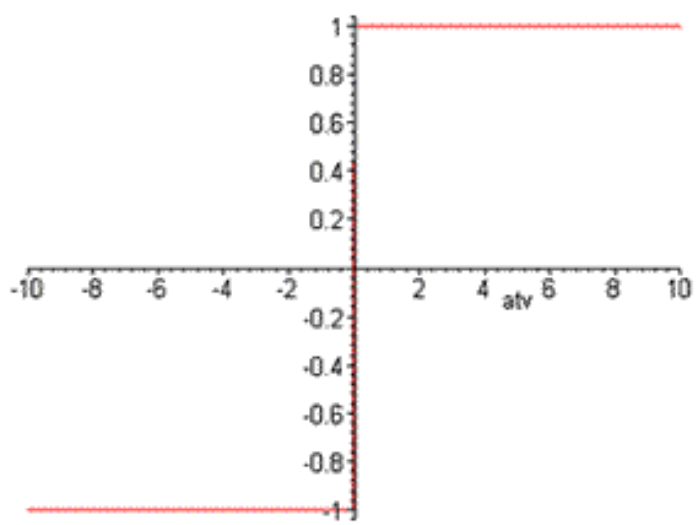

FIGURA 14 - Gráfico da Função Signun.

- Tangente Hiperbólica: Como a Função Logística, também possui forma de "s", assumindo valores entre 1 e -1 , sendo representada por.

$$
f(v)=a \frac{e^{(b v)}-e^{(-b v)}}{e^{(b v)}+e^{(b v)}}
$$

Onde:

$\boldsymbol{a}$ é o parâmetro de inclinação da curva;

$\boldsymbol{b}$ são os limites inferiores e superiores ( $b=1$ no gráfico);

$v$ é o valor de ativação da unidade. 


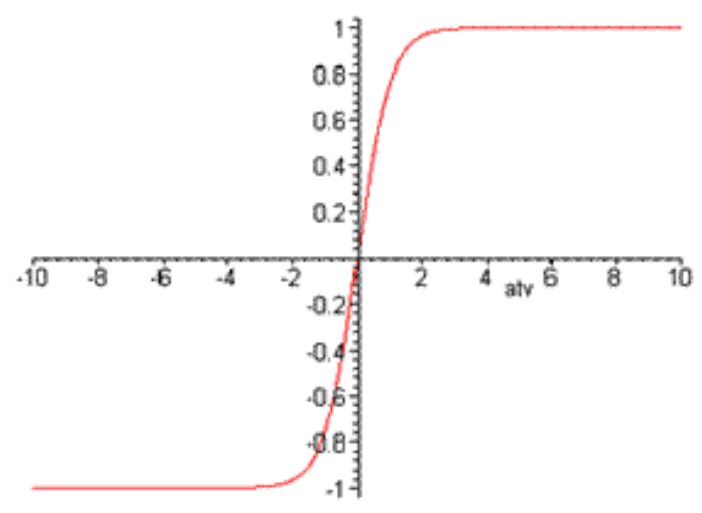

FIGURA 15 - Gráfico da Função Tangente Hiperbólica.

\section{4. - Arquiteturas de Redes Neurais Artificiais}

\subsection{1. - Perceptron}

No final da década de 1950, Rosenblatt na Universidade de Cornell, criou uma rede de múltiplos neurônios do tipo discriminadores lineares e chamou esta rede de perceptron. Um perceptron é uma rede com os neurônios dispostos em camadas (ver FIGURA 16). O modelo de distribuição denominado Perceptron é a forma mais simples de organização de uma RNA. Ela é composta por uma (single layer) ou mais camadas (multi-layer) utilizando sinais binários como entrada e saída para neurônios individuais.

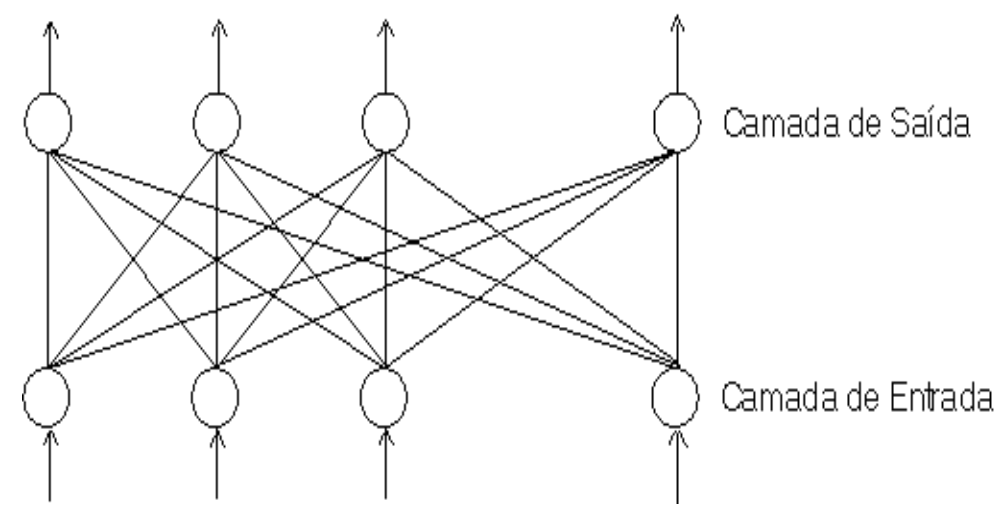

FIGURA 16 - Modelo Perceptron de Rosenblatt Multicamadas.

\subsection{2. - Adaline}

Semelhante ao modelo Perceptron, a rede neural do tipo Adaline (Adaptive Linear Element) também é distribuída em camadas, porém o sinal processado pelos neurônios 
possui valores contínuos e pertencentes ao domínio dos números reais, portanto não restritos a 0 e 1 . Esse fato expande a possibilidade do resultado processado pela rede em decisões que envolvem uma amplitude de valores bem maior que sim ou não.

Existem outros tipos de redes neurais, tais como:

\subsection{2. - Hopfield}

No modelo de RNA de Hopfield utiliza-se uma rede com ciclos com retroalimentação e comportamento dinâmico. Ele utiliza o mesmo neurônio binário de McCulloch e Pitts disposto em conexões em que as saídas ligam-se as entradas recursivamente.

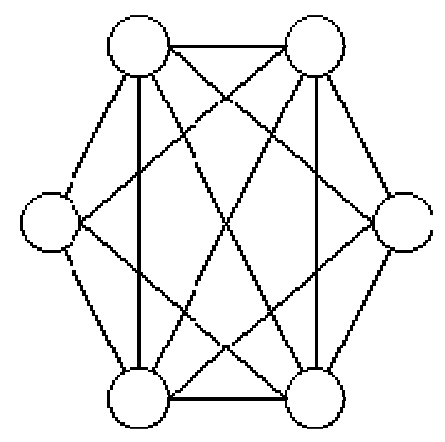

FIGURA 17 - Modelo de Hopfield.

\subsection{3. - Kohonen}

$\mathrm{O}$ modelo proposto por Kohonen acrescenta à RNA conceitos de aprendizado competitivo (não supervisionado), ou seja, os neurônios competem entre si para responder padrões de entrada formando assim grupos que se auto-organizam para processar determinado tipo de estímulo. 


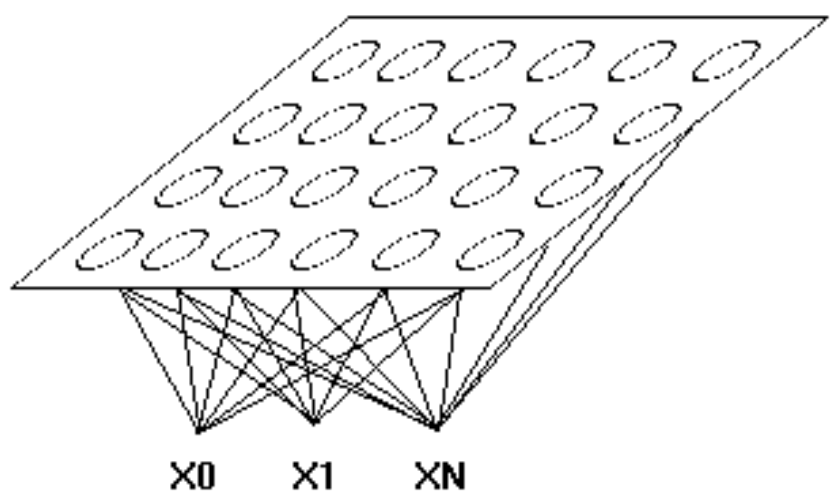

FIGURA 18 - Modelo de Kohonen.

As formas em que os neurônios da rede neural estão organizados estão intimamente ligadas ao algoritmo de aprendizado utilizado no treinamento da rede. Geralmente, podemos identificar três tipos de arquiteturas de RNA. [12]:

- Redes com propagação para frente de uma camada: são compostas por uma camada de entrada e outra de saída. (Ver FIGURA 19);

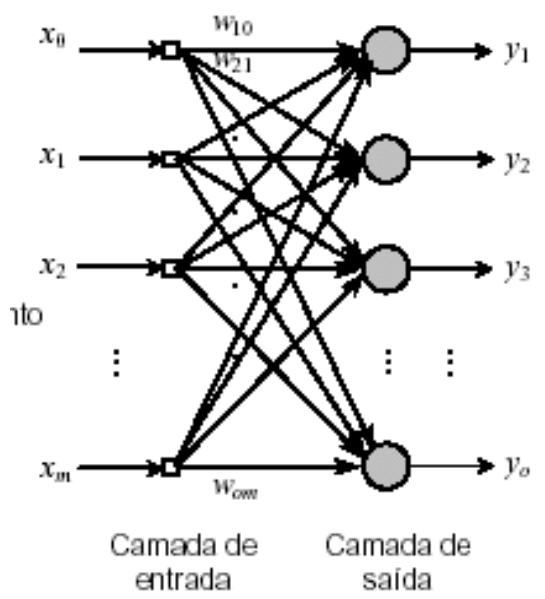

FIGURA 19 - Redes com propagação para frente de uma camada.

- Redes com propagação para frente de múltiplas camadas: são compostas por uma camada de entrada, uma ou mais camadas ocultas e uma camada de saída. (Ver FIGURA 20); 


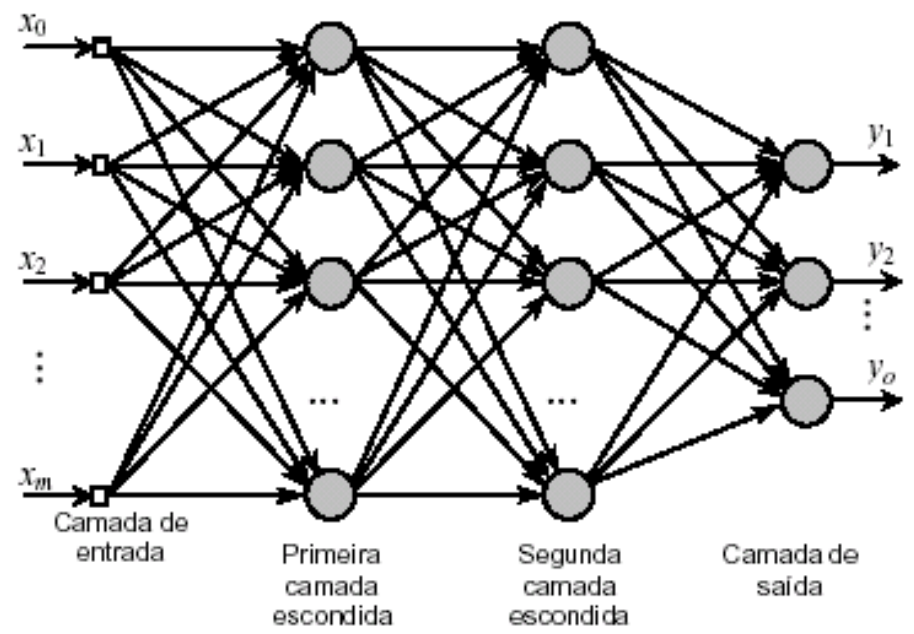

FIGURA 20 - Redes do tipo MLP (Múltiplas camadas com propagação para frente).

- Redes Recorrentes: contêm realimentação das saídas para as entradas, sendo suas saídas determinadas pelas entradas atuais e pelas saídas anteriores, (Ver FIGURA 21).

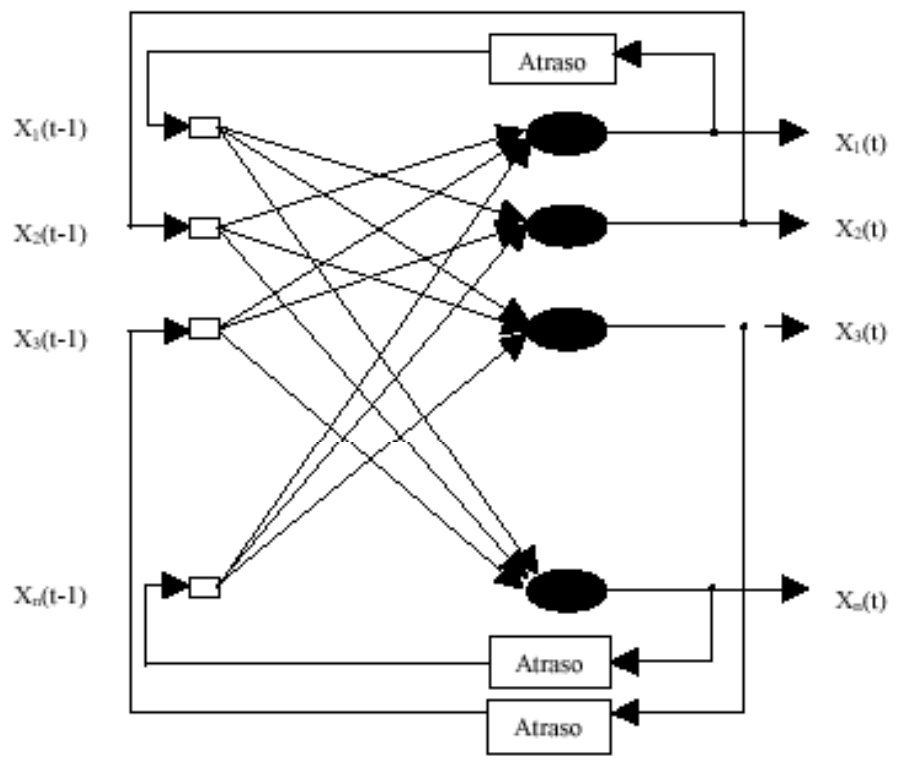

FIGURA 21 - Redes Recorrentes.

\section{5. - Algoritmos de Treinamento / Aprendizado}

Um aspecto importante em redes neurais é a definição das conexões entre os elementos de processamento e a definição dos pesos associados a essas conexões. Pode-se dizer que a informação armazenada e a computação realizada por uma determinada rede 
neural são definidas mais pela topologia de conexões entre elementos e pelos pesos atribuídos a essas conexões, do que propriamente pelos elementos de processamento individualmente. Em função disso, essas conexões entre os neurônios artificiais de uma rede são normalmente programáveis, e muitas vezes existem algum mecanismo do tipo "aprendizado", através do qual a rede "incorpora experiência a partir de exemplos que lhe são apresentados". Isto é particularmente interessante para a solução de problemas cuja especificação não é suficientemente estruturada, o que dificulta a sua representação em uma forma algorítmica (própria aos ambientes computacionais baseados em linguagens procedurais) ou mesmo na forma de uma lista de regras (própria às linguagens declarativas). Tal situação ocorre, por exemplo, nas tarefas de reconhecimento de padrões visuais, de reconhecimento de padrões de voz, e em leitura automática de textos manuscritos, e este é um dos motivos pelos quais as redes neurais são usadas nessas áreas. Este conceito de adaptação da rede face a uma descrição do problema que se pretende resolver através de exemplos dá origem a uma expressão que aparece com frequência no contexto de redes neurais: "redes neurais possuem a capacidade de aprender através de exemplos". Outra expressão comum que descreve essa característica é a que segue: "as informações são apresentadas à rede, que extrai informações a partir dos padrões apresentados".

Do ponto de vista matemático: os graus de liberdade das redes neurais (os pesos w) são adaptados de forma que um dado mapeamento entrada / saída desejado (e descrito por um repertório de pares entrada / saída chamados de exemplo de treinamento) seja obtido. Isto é realizado através de algum algoritmo de adaptação ou aprendizado, que tenha "características boas" em termos de viabilizar o aprendizado de um leque amplo de diferentes mapeamentos entrada / saída. Em resumo, a expressão "aprendizado da rede neural", nada mais significa do que o processo de adaptação educada dos pesos $\mathrm{w}_{\mathrm{i}}$ da rede, de forma a viabilizar o mapeamento entre entradas e saídas descritas por uma lista de exemplos representativos de uma dada aplicação. 


\section{6. - Principais Algoritmos de Treinamento}

Diversos métodos de aprendizado / treinamento foram desenvolvidos, sendo que podemos classificar os treinamentos das RNAs em duas classes:

Algoritmos de Aprendizado Supervisionado: são os de mais fácil entendimento. Neste tipo de aprendizado, as informações são apresentadas à rede sob a forma de padrões de entrada e dos resultados correspondentes desejados, conhecidos previamente. O algoritmo "supervisor" verifica as saídas geradas pela rede, para os padrões de entrada dos exemplos de treinamento, e as compara com as saídas desejadas, guiando assim o ajuste nas conexões sinápticas de forma a minimizar a diferença entre saída desejada e saída oferecida pela rede. Os algoritmos de aprendizado supervisionado mais conhecidos são o "Regra Delta”, para o Perceptron simples, e o "Retropropagação", para o MLP. Em ambos os casos, sempre que ocorre erro no reconhecimento de uma entrada, um ajuste sináptico é conduzido. $\mathrm{O}$ ajuste sináptico procura, portanto corrigir os pesos de modo que se produza a saída desejada diante da respectiva entrada, representando assim o aprendizado, em cada neurônio, do fato apresentado. Dessa forma, pode-se dizer que ao final do processo de aprendizado, o conhecimento dos neurônios da rede neural reside nos pesos sinápticos. [16]

O treinamento não-supervisionado: por sua vez, não requer vetor alvo para as saídas e, obviamente, não faz comparações para determinar a resposta ideal. O conjunto de treinamento modifica os pesos da rede de forma a produzir saídas que sejam consistentes. O processo de treinamento extrai as propriedades estatísticas do conjunto de treinamento e agrupa os vetores similares em classes, onde a aplicação de um vetor de uma determinada classe à entrada da rede produzirá um vetor de saída específico.

\subsection{1. - Modelagem em Redes Neurais artificiais}

Para o desenvolvimento de um modelo ou projeto baseado em redes neurais artificiais são necessárias diversas etapas: definição do problema; coleta dos dados de treinamento e de teste; pré e pós-processamento dos dados; projeto da estrutura da rede; treinamento; teste e validação.

Na elaboração do projeto da RNA ideal para solucionar um determinado problema, uma das tarefas mais difíceis é determinar o número de elementos de processamento da camada oculta, bem como o número de camadas ocultas (camadas intermediárias ou 
ocultas são as camadas onde é feita a maior parte do processamento, através de conexões ponderadas. Podem ser consideradas extratoras de características).

\subsection{2. - Aprendizagem Hebbiana}

A regra de aprendizado de Hebb's é a mais antiga de todas as regras de aprendizado [13]. Hebb's postulou que a adaptação das sinapses do sistema nervoso é proporcional à atividade dos neurônios pré e pós - sinápticos. A partir desse postulado, Hebb's desenvolveu um algoritmo para a atualização dos pesos, descrito pela equação (9):

$$
\Delta w_{i j}=\eta y_{j}(n) x_{j}(n)
$$

Onde:

$\eta \quad$ : é uma constante que expressa a taxa de aprendizado

$x_{j}(n)$ : entrada da rede

$y_{j}(n)$ : saída da rede

\subsection{3. - Aprendizagem por Correção de Erro}

Nesse processo de aprendizado têm-se como objetivo minimizar a diferença entre a saída calculada pela rede e a saída desejada, como mostra a equação (10):

$$
e_{j}(n)=y_{d j}(n)-y_{j}(n)
$$

Onde:

$e_{j}(n)$ : representa o erro do neurônio $j$

$j$ : neurônio

$y_{d j}(n)$ : saída desejada

$y_{j}(n)$ : saída calculada do neurônio $j$.

O erro $e_{j}(n)$ atua como um mecanismo de controle através da aplicação de uma seqüência de atualizações aos pesos sinápticos no neurônio j. As atualizações dos 
pesos sinápticos têm como objetivo aproximar a saída $y_{j}(n)$ da saída desejada $y_{d j}(n)$, através da minimização da energia do erro, $\varepsilon(n)$, definida em função do erro $e_{j}(n)$, como mostra a equação (11):

$$
\varepsilon(n)=\frac{1}{2} e_{j}^{2}(n)
$$

Onde :

$\varepsilon(n)$ : energia do erro

A equação (12) mostra como é feita a atualização dos pesos:

$$
w_{i j}(n+1)=w_{i j}(n)+\Delta w_{i j}(n)
$$

Onde:

$w_{i j}(n+1):$ peso atualizado

$w_{i j}(n)$ : peso antigo

O ajuste aos pesos sinápticos no neurônio $k$ continua, até que o sistema atinja a estabilidade. Logo após, o processo de aprendizado é interrompido.

\subsection{4. - Regra Delta ou Método do Gradiente Descendente}

O método do Gradiente Descendente tem como propósito principal minimizar uma função de erro, que é definida pela soma dos erros quadráticos, como mostra a equação (13):

$$
E=\frac{1}{2} \sum_{m=1}^{m}\left(y_{d j}(n)-y_{j}(n)\right)^{2}
$$


Onde:

$E$ : representa o erro

$m$ : número de neurônios na camada de saída

$y_{d j}:$ saída desejada

$y_{j}:$ saída calculada pela rede

No método do gradiente descendente verifica-se que com o decréscimo do erro, o peso tende a aumentar o que fortalece a ligação entre os neurônios. Quando ocorre a aumento do erro, o peso tende a diminuir, conforme a equação (14).

$$
w_{i j}(n+1)=w_{i j}(n)-\eta \frac{\partial E}{\partial w_{i j}}
$$

Onde:

$$
\begin{aligned}
& w_{i j}(n+1): \text { peso atualizado } \\
& w_{i j}(n): \text { peso antigo } \\
& \eta: \text { taxa de aprendizado } \\
& \frac{\partial E}{\partial w_{i j}}: \text { gradiente }
\end{aligned}
$$

O algoritmo de retropropagação, que foi utilizado no treinamento das RNA's deste trabalho, utiliza a regra delta generalizada. Este algoritmo será descrito em detalhes, no próximo tópico.

\subsection{5. - Algoritmo de Retropropagação}

O algoritmo de Retropropagação serviu como base para a maioria dos algoritmos de aprendizagem existentes e foi a partir da sua concepção que ressurgiu o interesse pela área de Redes Neurais Artificiais, depois de um longo tempo de espera. O Retropropagação é um algoritmo supervisionado que utiliza pares, formados pela entrada e saída desejada, para ajustar os pesos da rede. O treinamento ocorre em duas fases: forward e backward. 
A implantação computacional do algoritmo de retropropagação apresenta os seguintes passos: [18]

Passo 1: Inicialização de todos os pesos e parâmetros.

Passo 2: Fase forward, consiste em:

Dadas as entradas, calcular as saídas para todas as camadas da rede;

Calcular o erro de saída da rede.

Passo 3: Fase backward, consiste em:

Efetuar o cálculo das atualizações dos pesos entre as camadas da rede, iniciando a partir da última camada, até chegar a camada de entrada;

O algoritmo de retropropagação consiste na utilização dos pesos, considerando a propagação do erro da saída da rede para a sua entrada. Este algoritmo é também conhecido como regra delta generalizada.

Embora o erro total E seja definido pela soma dos erros dos neurônios de saída para todos os padrões, será considerado sem perda de generalidade, que a minimização do erro para cada padrão individualmente levará à minimização do erro total para todos os padrões. Portanto, o erro passa a ser definido conforme a equação (14), descrita anteriormente.

Como na regra delta a variação dos pesos é definida de acordo com o gradiente decrescente, partindo-se da equação (15) é calculada matematicamente a equação (16), sendo $\Delta w=w(n+1)-w(n)$ :

$$
\Delta w_{i j}=-\eta \frac{\partial E}{\partial w_{i j}}
$$

Logo: 


$$
\begin{aligned}
& \Delta w_{i j}=-\eta \frac{\partial E}{\partial w_{i j}}=-\eta \cdot \frac{\partial E}{\partial y_{j}} \cdot \frac{\partial y_{j}}{\partial w_{i j}} \\
& y_{j}=\left(\sum_{m=1}^{m} x_{j} w_{i j}\right) \\
& \Delta w_{i j}=-\eta \cdot\left[2 \cdot \frac{1}{2} \cdot\left(y_{d j}-y_{j}\right) \cdot(-1)\right] \cdot x_{j} \\
& \Delta w_{i j}=-\eta \cdot\left[-\left(y_{d j}-y_{j}\right)\right] \cdot x_{j} \\
& \Delta w_{i j}=x_{j} \cdot \eta \cdot\left(y_{d j}-y_{j}\right)
\end{aligned}
$$

Onde:

$w$ : indica o valor dos pesos

$y_{d j}$ : saída desejada

$y_{j}$ : saída calculada pela rede

$\eta$ : taxa de aprendizado

$x_{j}$ :entrada da rede 


\section{5. - DESCRIÇÃO DO ARRANJO EXPERIMENTAL PARA OS TESTES DE IMERSÃO RÁPIDA E TESTE DE RESPOSTA A UM DEGRAU DE CORRENTE (LCSR)}

Para a realização dos testes LCSR são utilizados os seguintes equipamentos:

- Sensores de temperatura do tipo RTD;

- Banho térmico e agitador;

- Maleta contendo circuito eletrônico para realização dos testes LCSR;

- Sistema de aquisição de dados.

A seguir tem-se uma descrição de cada item.

\section{- Sensores do tipo RTD;}

Na FIGURA 22 temos sensores do tipo RTD, da marca: Rosemount, modelo: 4 fios, classe A, 1/4" de diâmetro, estes sensores têm uma faixa de trabalho de -200 a $500{ }^{0} \mathrm{C}$

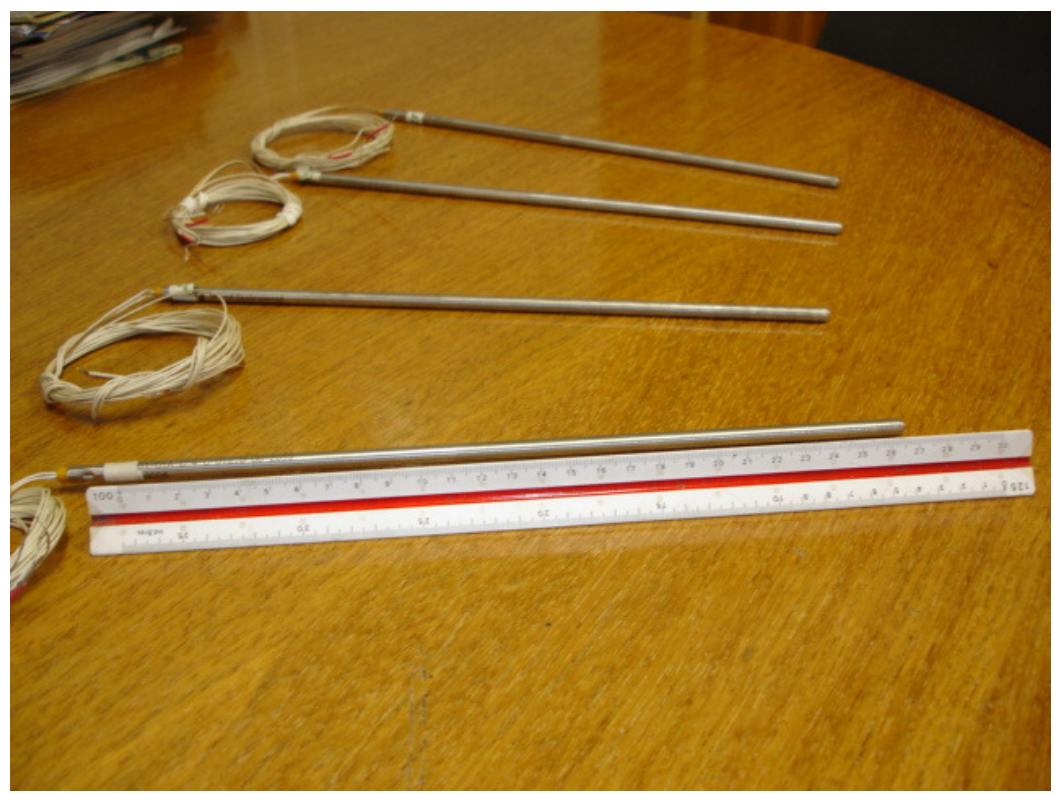

FIGURA 22 - Sensores do tipo RTD.

- Banho térmico;

Na FIGURA 23 temos o banho térmico da marca GEBRUDER HAAKE, modelo FT, com controle de temperatura até $350^{\circ} \mathrm{C}$, usando para controle de temperatura um resistor de platina. Este banho permite o ajuste e controle de temperatura mantendo constante a vazão. 


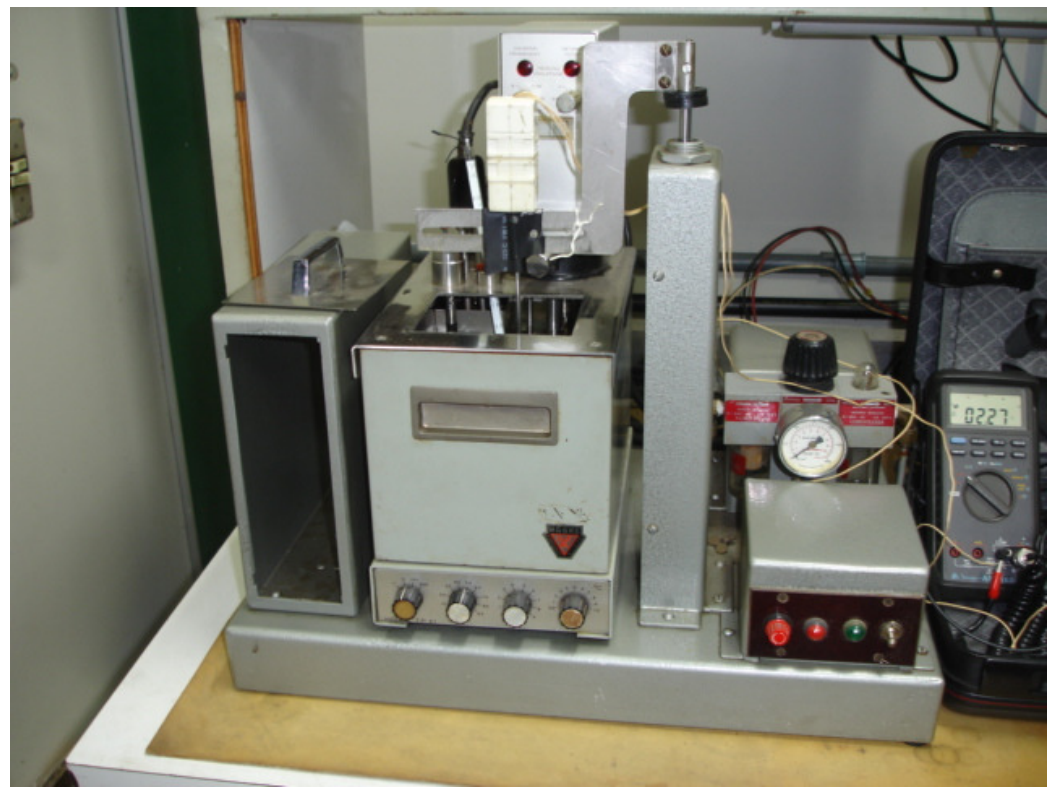

FIGURA 23 - Banho Térmico.

- Maleta para medida de LCSR e Teste de imersão rápida;

Na FIGURA 24 tem-se a maleta que contém um circuito com uma ponte de Wheatstone para teste Imersão Rápida e LCSR de RTDs. Este circuito é composto além da ponte de Wheatstone por uma chave seletora para dar o degrau de corrente, um amplificador com ajuste de ganho para X3, X5, X10, X40, X60 e possibilita também se necessário uma conexão com uma década de resistores externa.

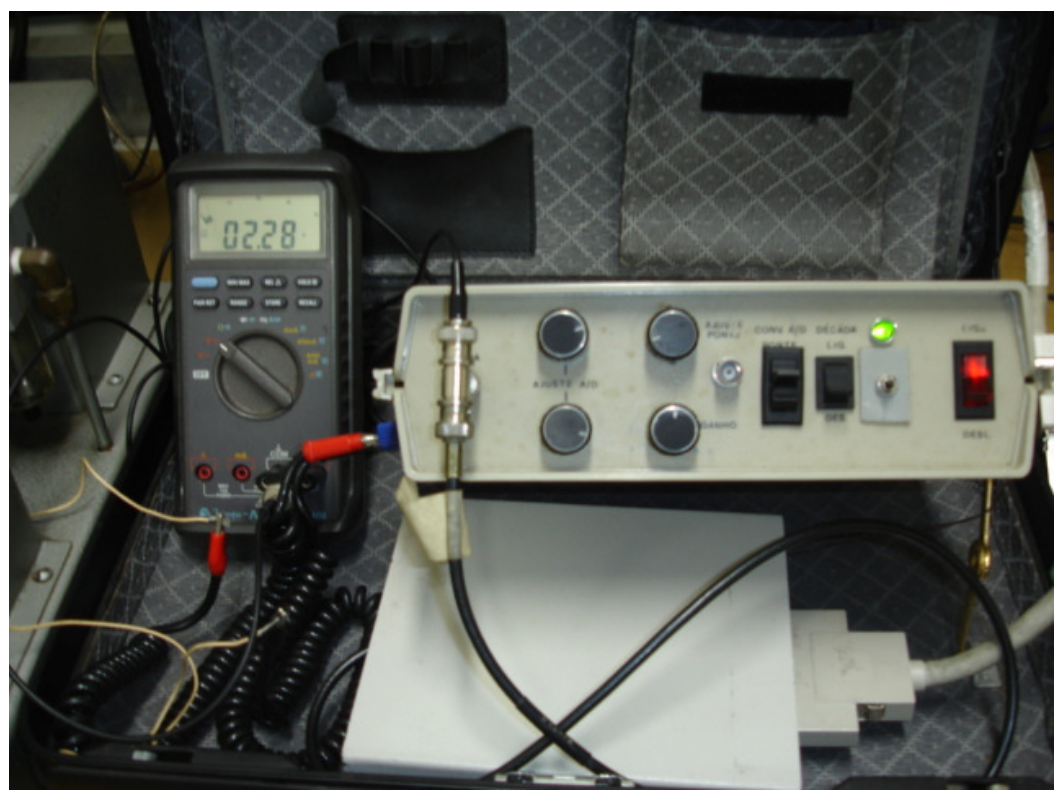

FIGURA 24 - Maleta para medida de LCSR e Teste de imersão rápida. 
- Sistema de aquisição de dados;

Na FIGURA 25 tem-se o sistema de aquisição de dados. Este sistema é composto por um microcomputador laptop Pentium IV com Windows XP e programa para aquisição de dados desenvolvido em plataforma Labview, placa de aquisição de dados da National Instruments modelo DAQCard-6024E e uma caixa de conexão da National Instruments modelo SCB 68.

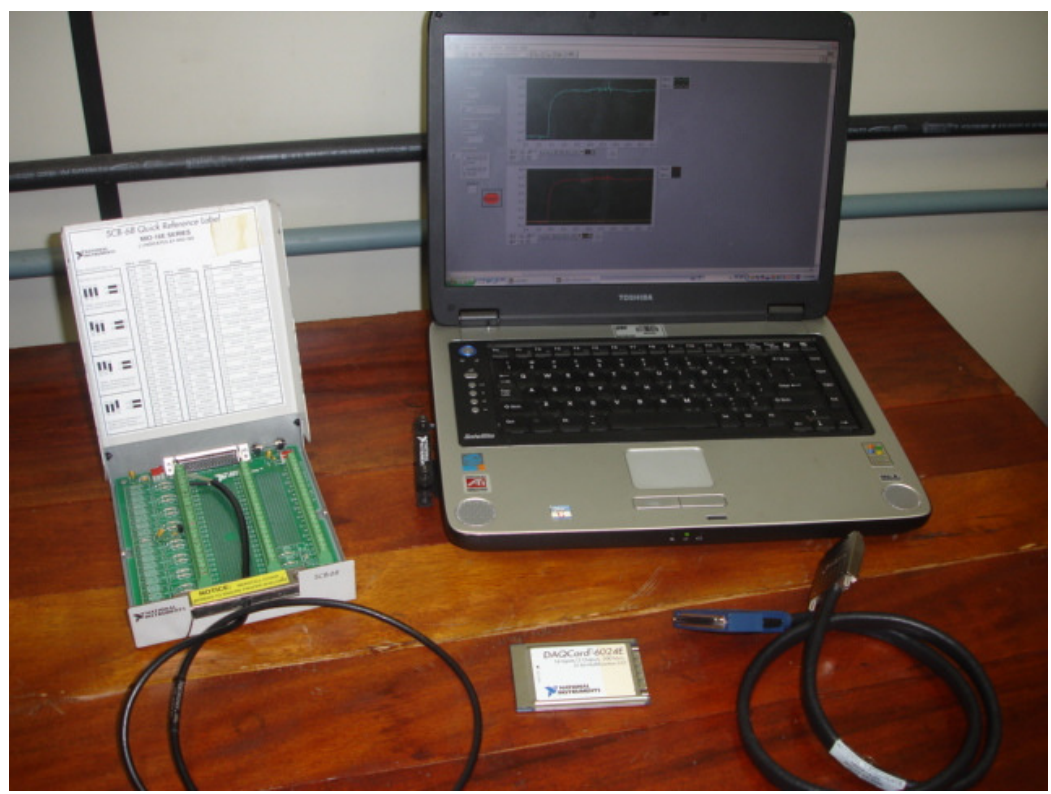

FIGURA 25 - Sistema de aquisição de dados.

- Agitador

Agitador magnético com aquecimento, marca Fisatom, modelo 753A, agita até 10 litros, diâmetro da placa $18 \mathrm{~cm}$, altura $10,5 \mathrm{~cm}$, potência $1000 \mathrm{~W}$, faixa de rotação 110 $1180 \mathrm{rpm}$. 


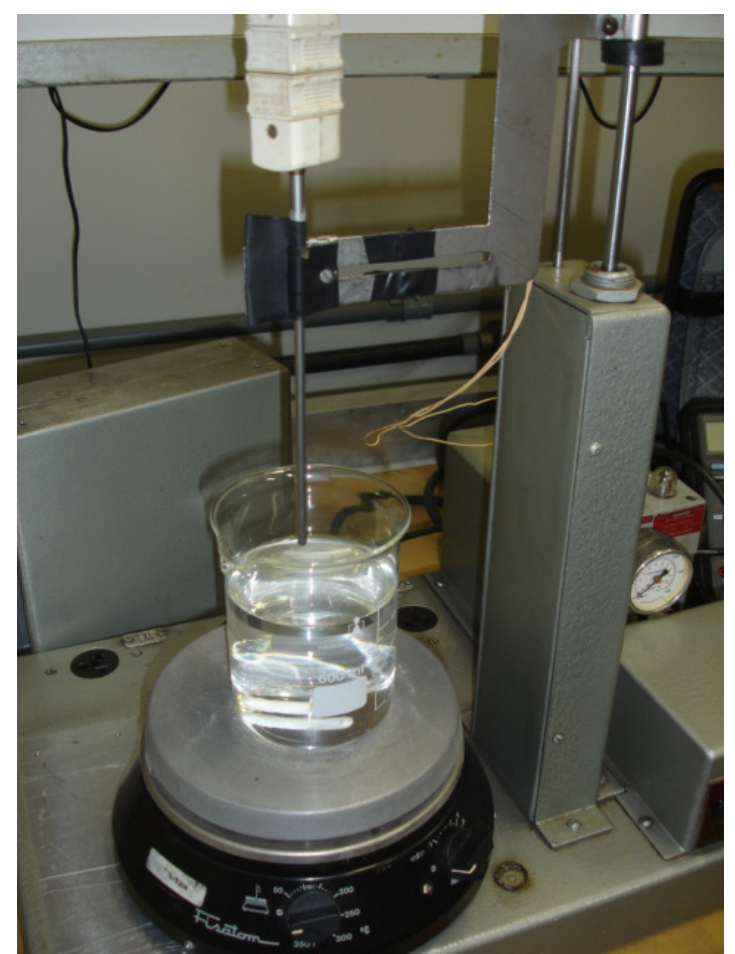

FIGURA 26 - Agitador Magnético. 


\section{6. - RESULTADOS}

Para este trabalho foi usada a toolbox Neural Networks do Matlab [19], utilizando uma rede do tipo Multi Layer Perceptron (MLP), onde o algoritmo de aprendizado foi a retropropagação. Os algoritmos de retropropagação são algoritmos supervisionados que utilizam pares de entradas/saídas desejadas descrito no capítulo 4.

Os dados de entrada da rede são os dados obtidos pelo teste LCSR e os dados de saída são as constantes de tempo do sensor dado pelo Teste de imersão Rápida (Plunge test).

Com a finalidade de estudar o desempenho das Redes Neurais na determinação da constante de tempo do sensor de temperatura RTD foram geradas seis RNAs, sendo uma rede utilizando dados teóricos e cinco redes utilizando dados experimentais de três RTDs diferentes. Finalmente foi criada uma rede neural utilizando dados experimentais dos três sensores.

Além disso, foi estudada a influência da normalização dos dados experimentais. Para isso foi feita uma rede neural sem a normalização e outra com a normalização para o sensor 1. As redes neurais resultantes sãos:

- RNA com dados teóricos;

- RNA com dados do Sensor 1 (Sem normalizar);

- RNA com dados do Sensor 1;

- RNA com dados do sensor 2;

- RNA com dados do sensor 3;

- RNA utilizando dados dos sensores 1,2 e 3.

\section{1 - RNA com dados teóricos}

Com base na teoria do teste de LCSR (Vide capítulo 3) os dados experimentais obtidos do teste LCSR são ajustados a uma somatória de exponenciais. A partir desse ajuste obtêm-se os valores dos coeficientes $A_{i}$ e $\tau_{i}$ da equação 1.

$$
T(t)=A_{0}+A_{1} e^{-t / \tau_{1}}+A_{2} e^{-t / \tau_{2}}+\ldots+A_{n} e^{-t / \tau_{n}}
$$


Os dados teóricos para esta rede foram gerados utilizando apenas dois termos exponenciais, como dado pela equação 1, pois se consegue distinguir até dois termos exponenciais na prática. $[8,9,10]$

$$
T(t)=A_{0}+A_{1} e^{-t / \tau_{1}}+A_{2} e^{-t / \tau_{2}}
$$

Simulando 10 sensores com diferentes valores de constante de tempo, foram geradas 10 curvas com o teste a um degrau de corrente com 200 pontos cada uma delas, atribuindo-se diferentes valores para $\tau_{1}$ e $\tau_{2}$. Os valores dos coeficientes foram escolhidos arbitrariamente como: $\mathrm{A}_{0}=2 ; \mathrm{A}_{1}$ e $\mathrm{A}_{2}=-1$. Os valores de $\tau_{1}$ e $\tau_{2}$ também foram escolhidos arbitrariamente, e estão definidos na TABELA 1.

A equação das curvas geradas e o valor da constante de tempo de cada curva são mostrados na TABELA 1. Na FIGURA 27 são mostradas as curvas geradas como sinal de entrada da rede e na FIGURA 28 estão os dados de saída que são as constantes de tempo calculadas.

TABELA 1 - Constante de tempo de cada curva gerada

$$
T(t)=2-e^{-t / \tau 1}-e^{-t / \tau 2}
$$

\begin{tabular}{|c|c|c|c|}
\hline Curva & $\boldsymbol{\tau}_{\mathbf{1}}$ & $\boldsymbol{\tau}_{\mathbf{2}}$ & $\boldsymbol{\tau}$ \\
\hline 1 & 0,5 & 0,005 & 0,505 \\
\hline 2 & 0,6 & 0,006 & 0,606 \\
\hline 3 & 0,7 & 0,007 & 0,707 \\
\hline 4 & 0,8 & 0,008 & 0,808 \\
\hline 5 & 0,9 & 0,009 & 0,909 \\
\hline 6 & 1,0 & 0,010 & 1,010 \\
\hline 7 & 1,1 & 0,011 & 1,111 \\
\hline 8 & 1,2 & 0,012 & 1,212 \\
\hline 9 & 1,3 & 0,013 & 1,313 \\
\hline 10 & 1,4 & 0,014 & 1,414 \\
\hline
\end{tabular}


O valor de $\tau$ é calculado de acordo com a equação (2). Vide capítulo 3 (Metodologia)

$$
\tau=\tau_{1}\left[1-\ln \left(1-\frac{\tau_{2}}{\tau_{1}}\right)\right]
$$

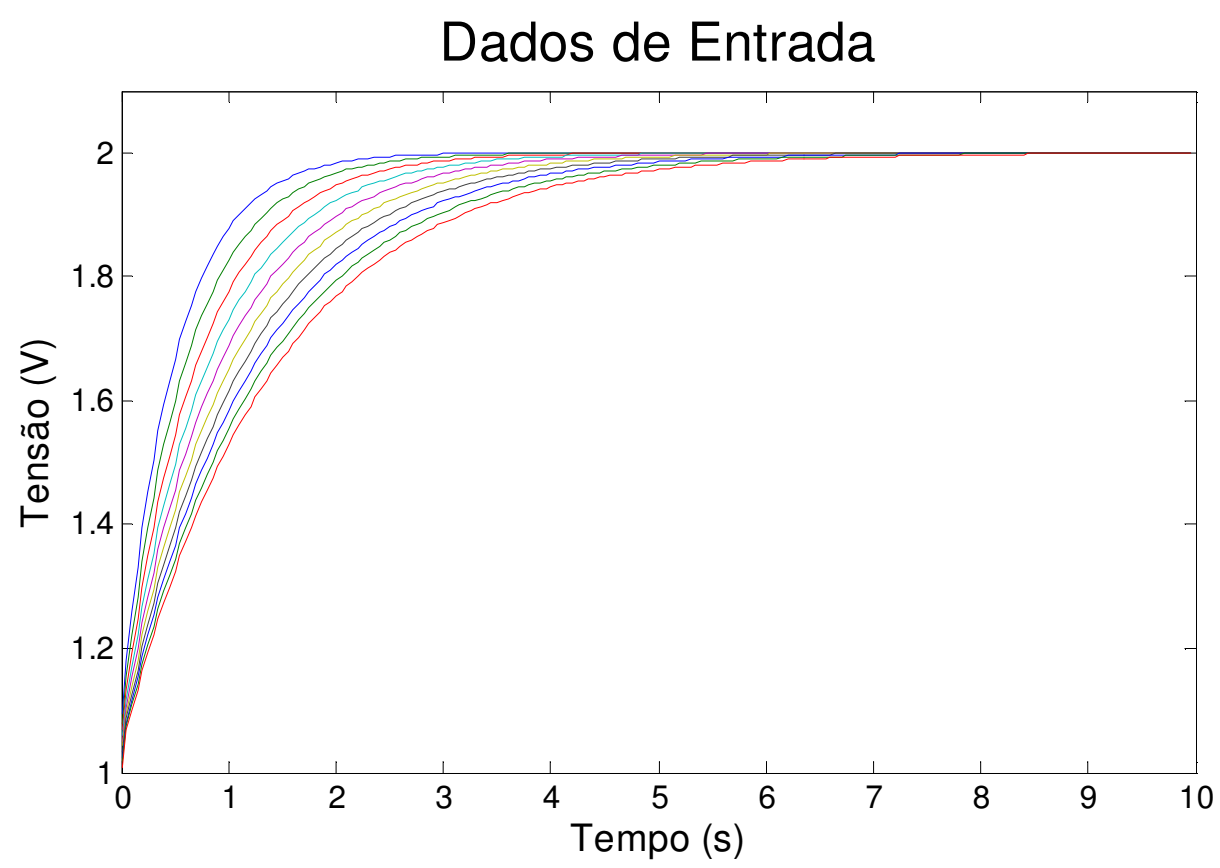

FIGURA 27 - Dados de entrada da rede Teórica.

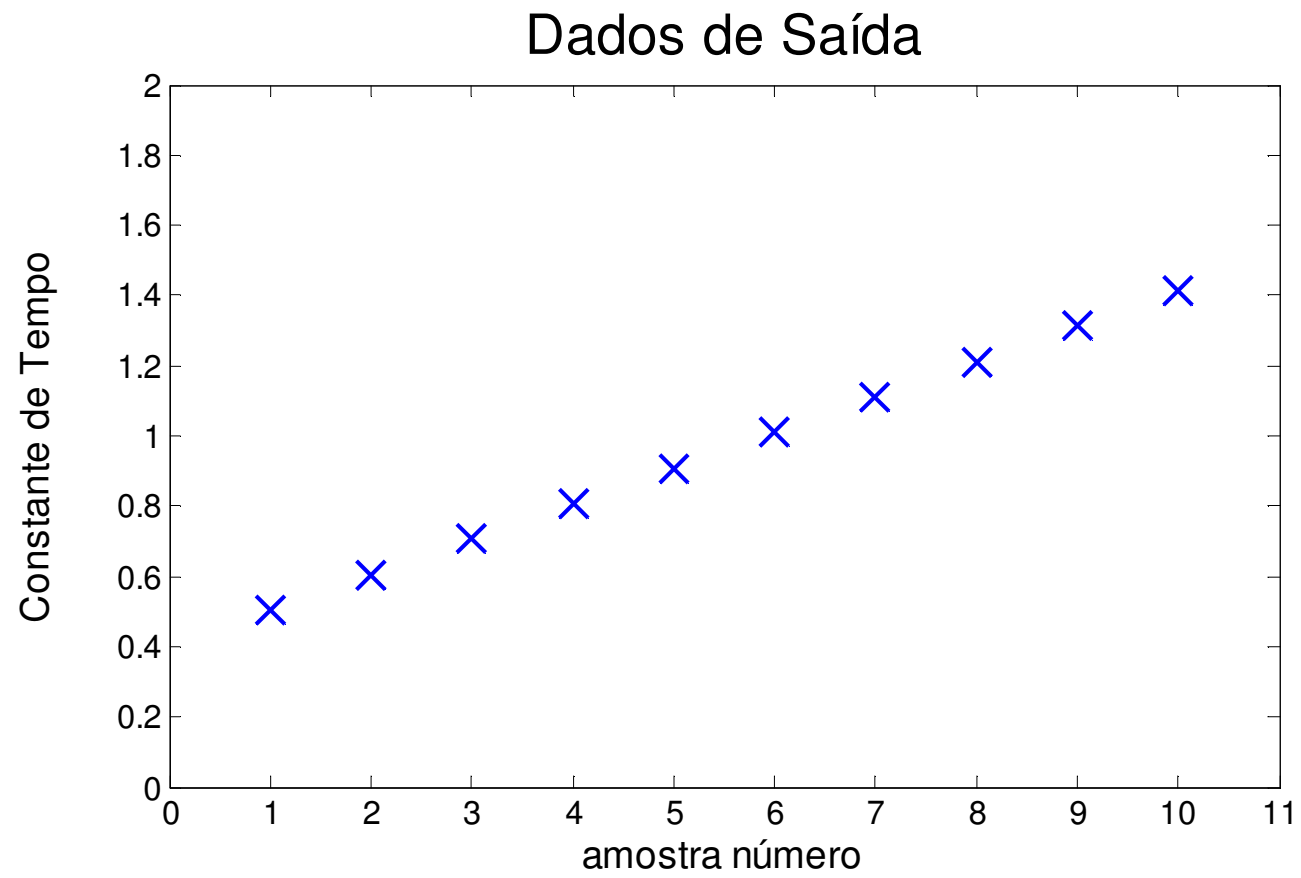

FIGURA 28 - Dados de Saída da Rede Teórica. 
A rede foi modelada com 1 camada de entrada, 1 camada oculta com 3 neurônios e uma camada de saída, tendo 10 sinais de entrada e 10 sinais de saída, com treinamento máximo de 100 épocas e com um erro aceito em até $0,001$.

Para a entrada de treinamento da rede foi usado $60 \%$ dos sinais sendo as curvas 1 , 3, 5, 7, 9, 10 e como saída treinamento as constantes de tempo correspondentes. Para entrada teste foi usado $40 \%$ dos sinais ficando então as curvas $2,4,6,8$, e saída teste os valores de constante de tempo correspondentes.

Como descrito no capítulo 4 (Redes Neurais), foi usada uma rede do tipo MLP (Multi Layer Perceptron) e como algoritmo de treinamento foi usado o de Retropropagação e a função de treinamento usada foi a Trainlm, que atualiza o peso e o "bias" de acordo com a otimização de Levenberg-Marquardt [19].

A função de desempenho utilizada foi o erro médio quadrático (mean square error MSE) entre as saídas da rede e as saídas desejadas.

Na FIGURA 29 podemos observar a desempenho de treinamento da rede onde a rede conseguiu convergir em 4 épocas com um erro atingido de 3,85995e-5.

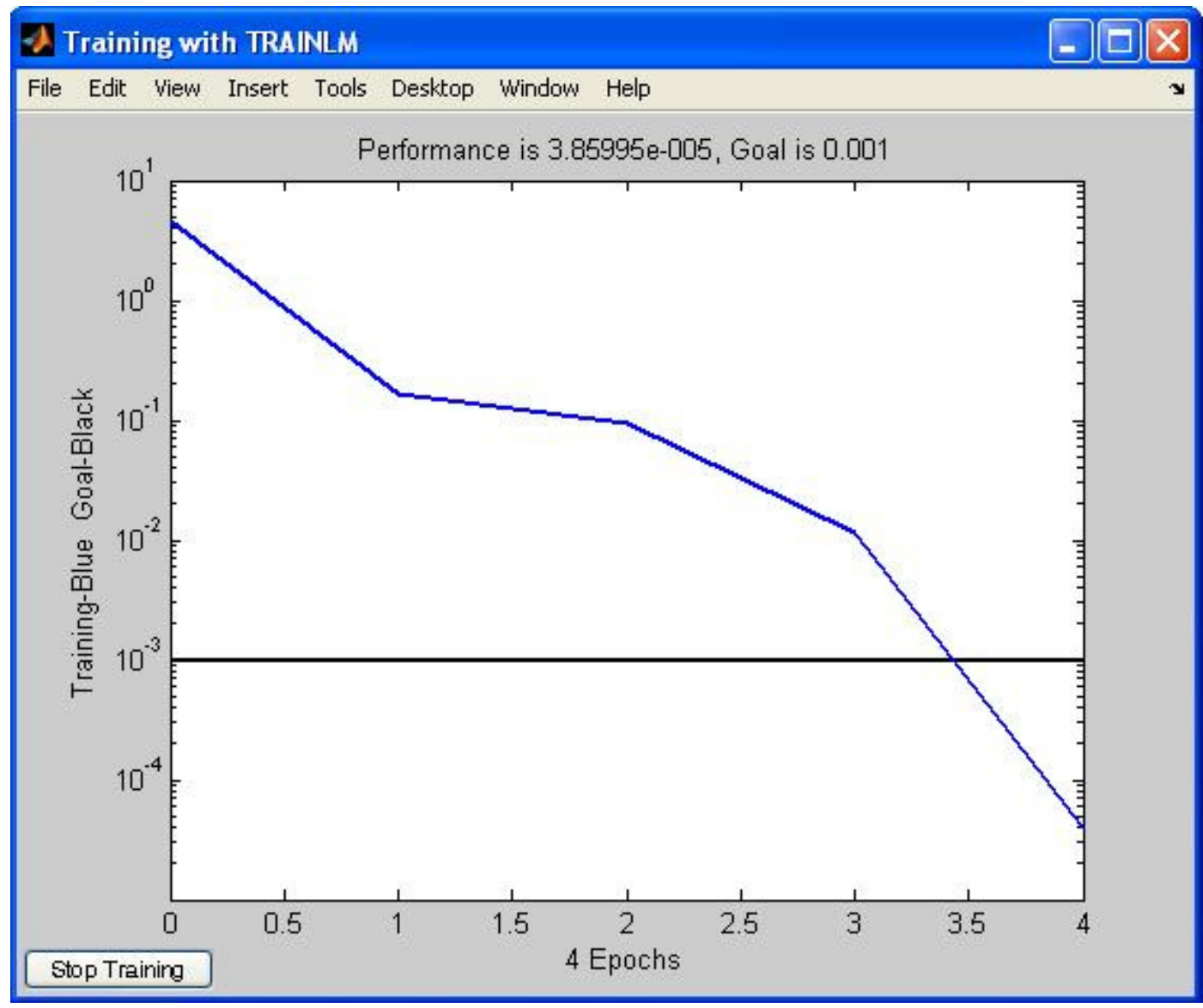

FIGURA 29 - Gráfico do Treinamento da Rede Teórica. 
A seguir a FIGURA 30 mostra a comparação entre a saída da RNA e o alvo (Treinamento).

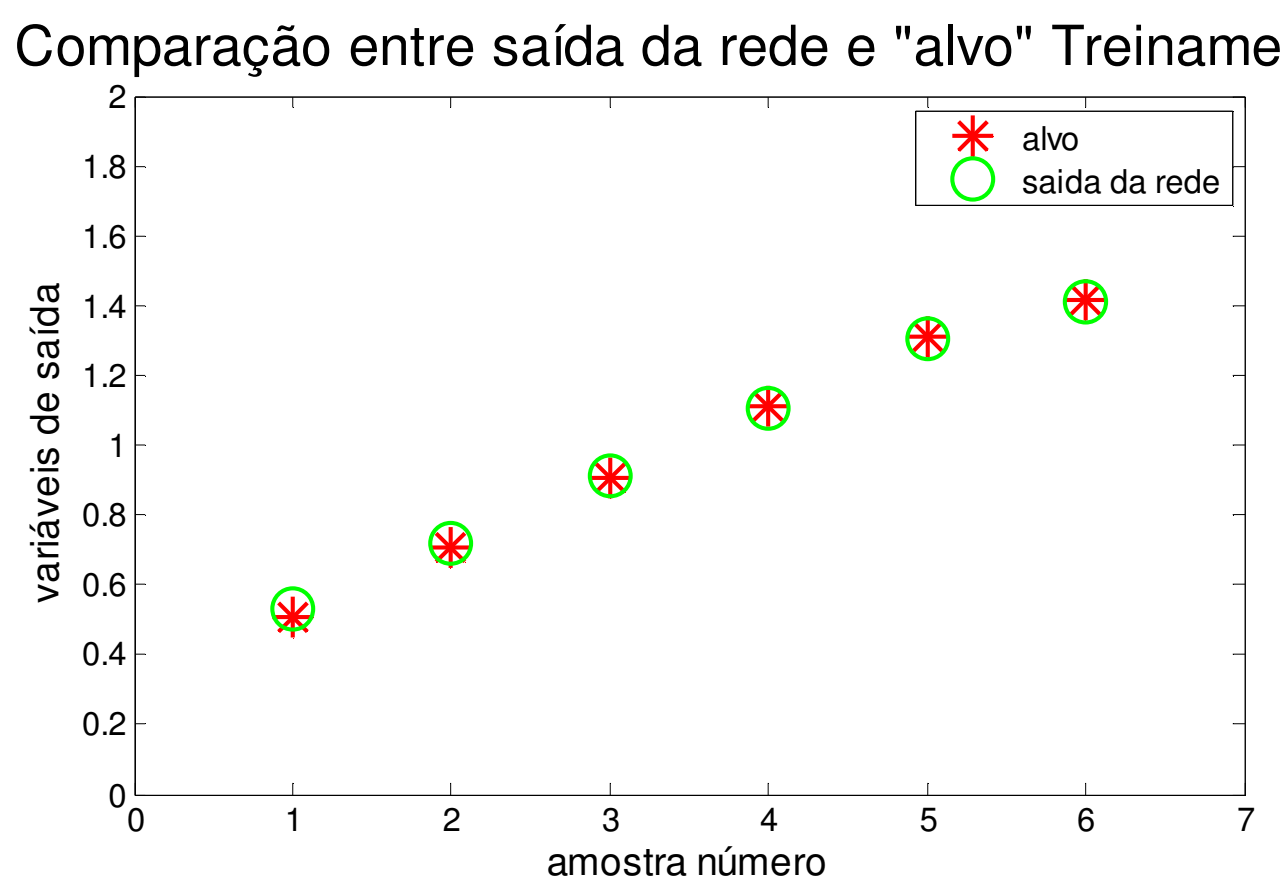

FIGURA 30 - Gráfico de comparação entre saída da rede e alvo (treinamento).

A rede treinada foi então utilizada para calcular a constante de tempo com os dados de entrada do grupo "teste", os resultados estão mostrados na figura 31.

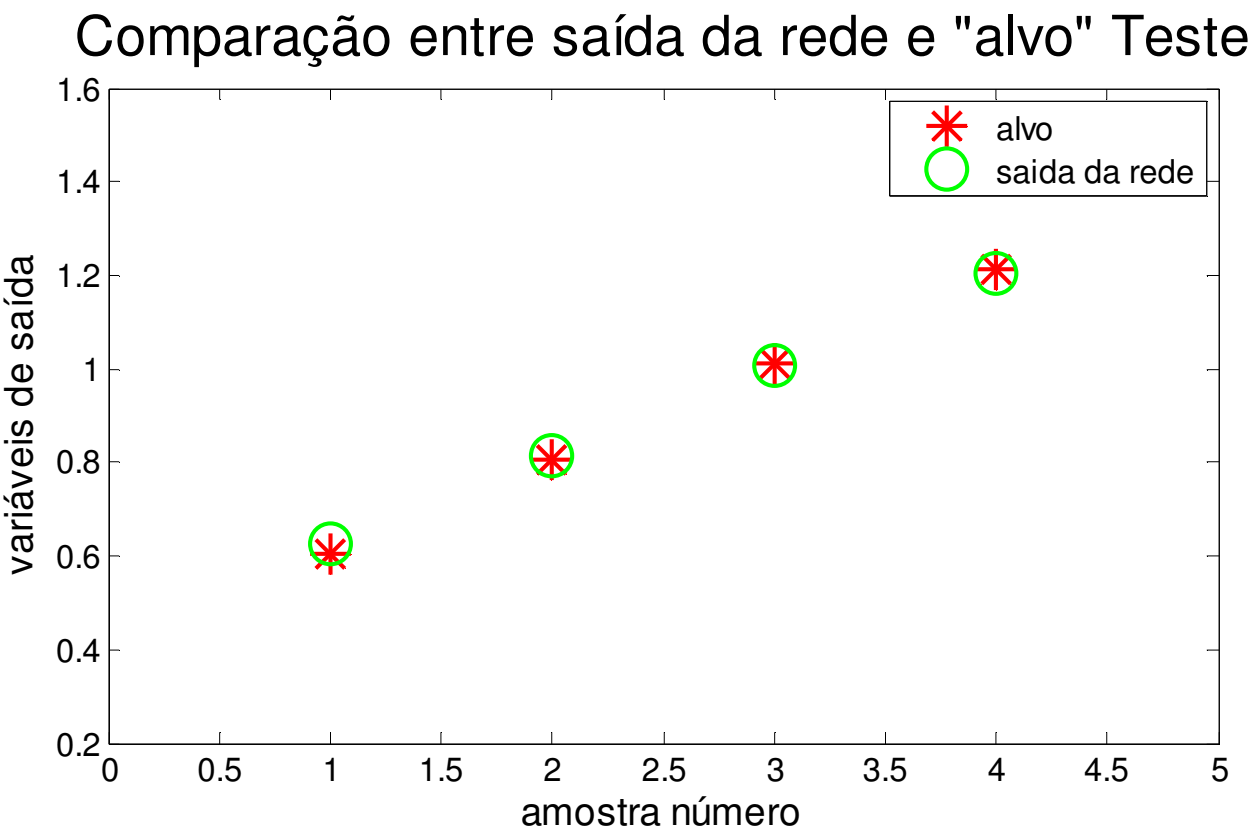

FIGURA 31 - Gráfico de comparação entre saída da rede e alvo (Teste). 
Na TABELA 2 é mostrada a comparação entre a constante de tempo desejada (Alvo) e a constante de tempo dada pela RNA utilizada.

TABELA 2 - Resultados Teóricos

\begin{tabular}{|c|c|c|c|c|}
\hline & Sensor & $\begin{array}{c}\text { Constante de tempo } \\
\text { Esperado } \\
\text { (Alvo) } \\
\text { (s) }\end{array}$ & $\begin{array}{l}\text { Constante de } \\
\text { tempo RNA } \\
\text { (Saída) } \\
\text { (s) }\end{array}$ & $\begin{array}{c}\text { Erro } \\
\text { Quadrático } \\
\text { (MSE) }\end{array}$ \\
\hline \multirow{6}{*}{ TREINAMENTO } & 1 & 0,505 & 0,5162 & \multirow{6}{*}{3,8599 e -5} \\
\hline & 3 & 0,707 & 0,7113 & \\
\hline & 5 & 0,909 & 0,9029 & \\
\hline & 7 & 1,111 & 1,1042 & \\
\hline & 9 & 1,313 & 1,3109 & \\
\hline & 10 & 1,414 & 1,4145 & \\
\hline & & & & \\
\hline \multirow{4}{*}{ TESTE } & 2 & 0,606 & 0,6156 & \multirow{4}{*}{4,3788 e -5} \\
\hline & 4 & 0,808 & 0,8061 & \\
\hline & 6 & 1,010 & 1,0024 & \\
\hline & 8 & 1,212 & 1,2074 & \\
\hline
\end{tabular}

Após os testes utilizando dados teóricos, foram feitos testes utilizando dados experimentais obtidos com sensores de temperatura do tipo RTD.

\section{2. - RNA com dados do Sensor 1}

Inicialmente foi modelada uma RNA com dados de um sensor do tipo RTD (Resistance Temperature Detector) PT100 com 4 fios. Este sensor tem 3,25 mm de diâmetro externo $250 \mathrm{~mm}$ de comprimento. A FIGURA 32 mostra o sensor utilizado.

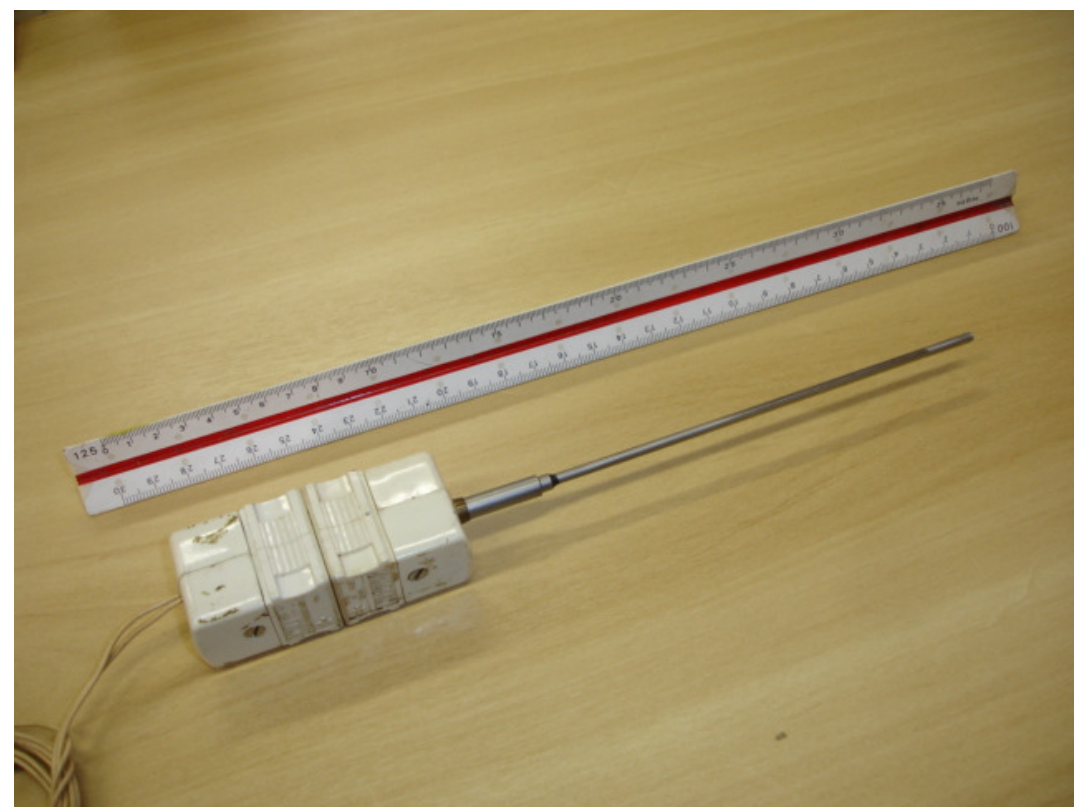

FIGURA 32 - Sensor 1 
Os dados para esta rede foram gerados aplicando o teste de resposta a um degrau de corrente descrito no item 3.2. Foram realizados 10 testes, gerando 10 curvas com 362 pontos cada curva. Os pontos destas curvas foram usados como dados de entrada da rede, como mostrado na FIGURA 33. O tempo de resposta do sensor foi obtido pelo teste de imersão rápida que foi realizado 10 vezes. Os testes foram realizados todos nas mesmas condições de temperatura ambiente e temperatura do banho térmico.

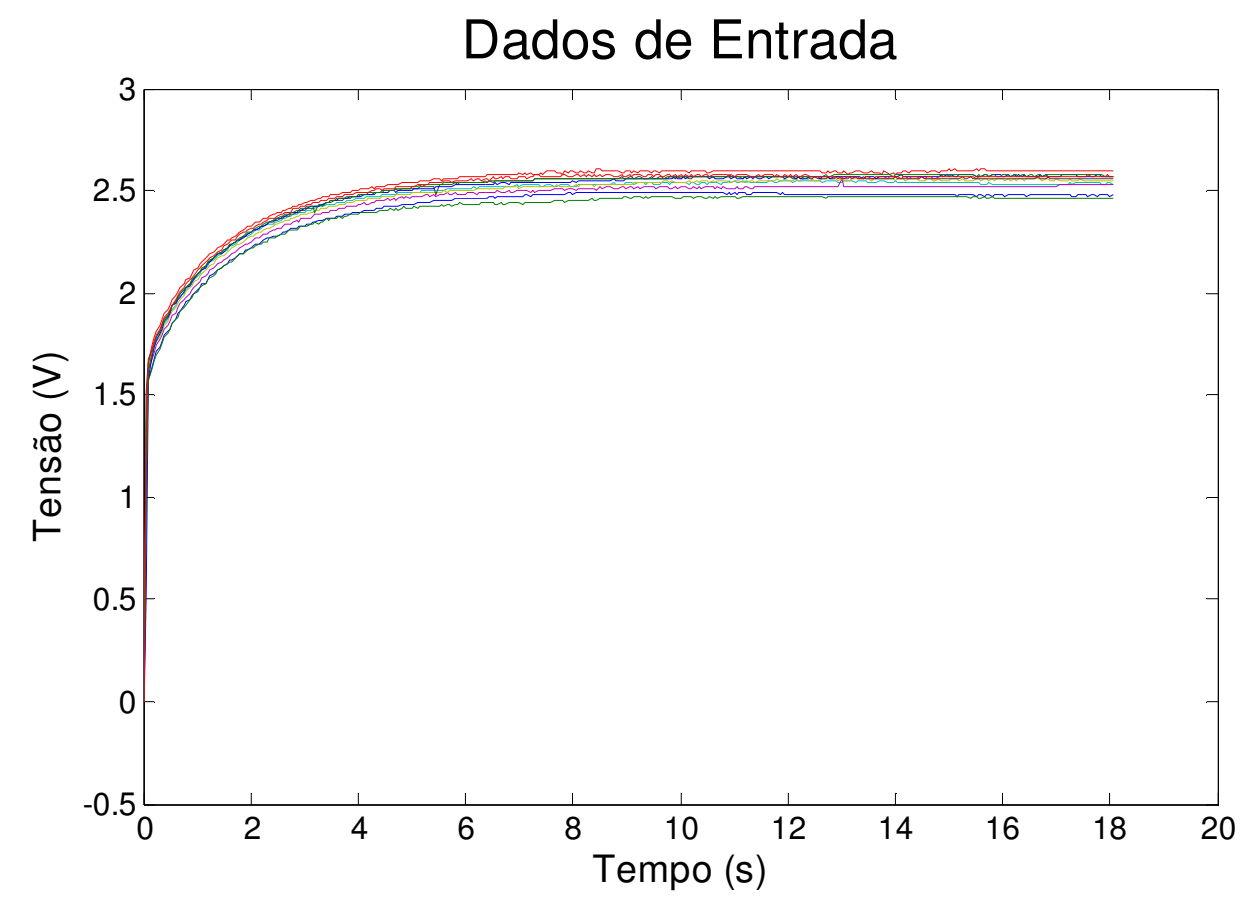

FIGURA 33 - Dados de entrada da rede do sensor 1.

Esta rede também foi modelada como a anterior. A seguir tem-se a FIGURA 34 mostrando dados de saída da rede para o sensor 1 e a FIGURA 35 mostra o gráfico do desempenho do treinamento da Rede. 


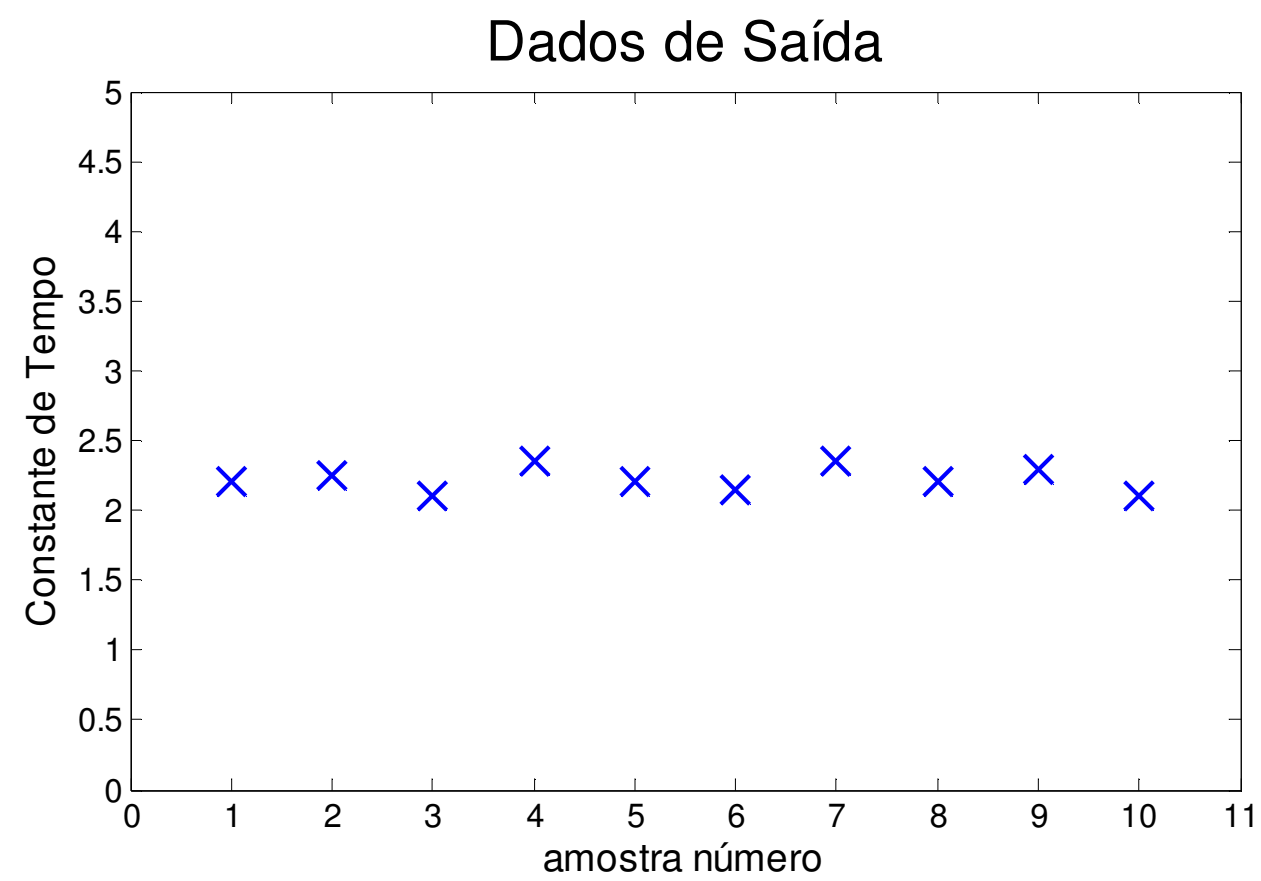

FIGURA 34 - Dados de Saída da Rede sensor1.

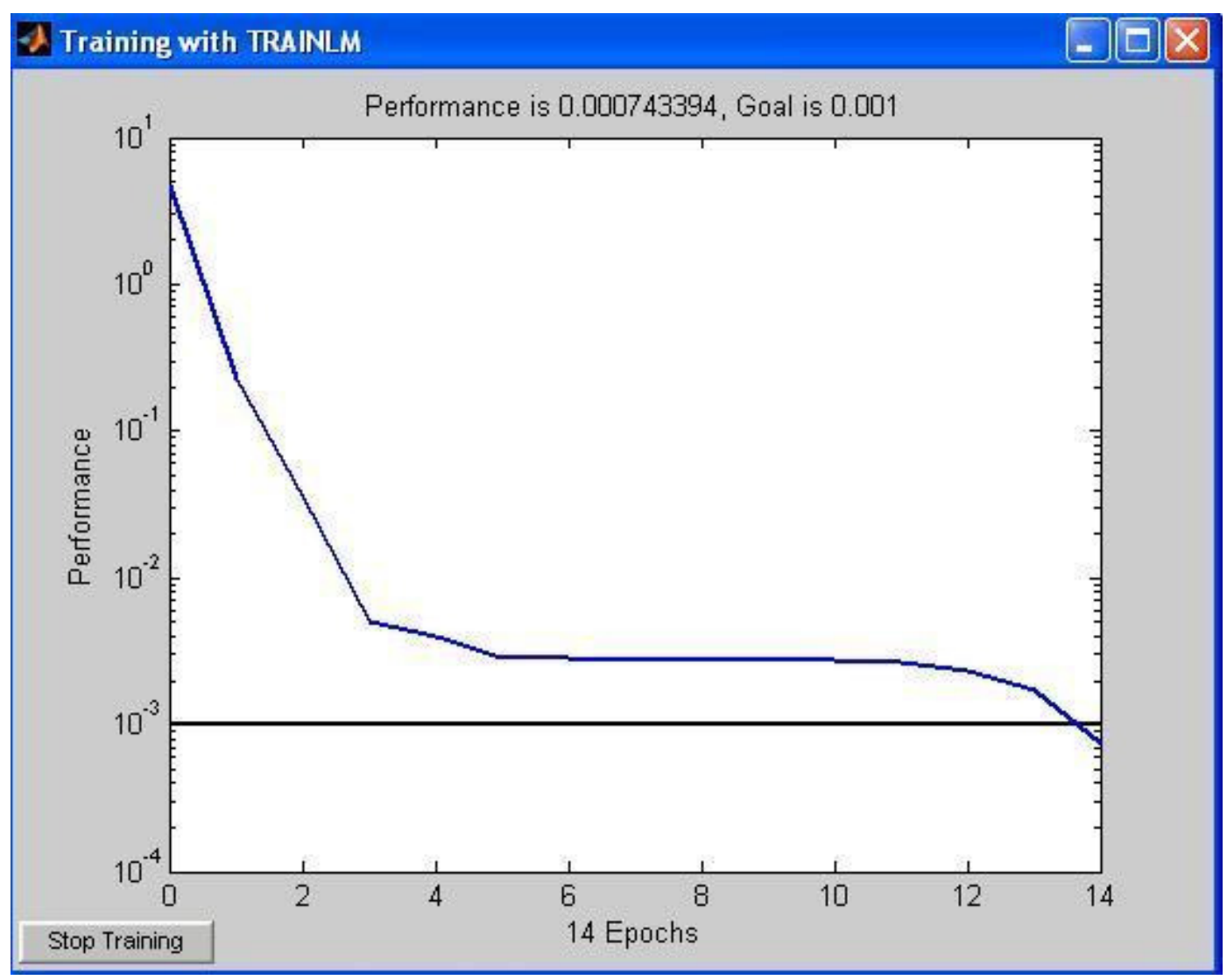

FIGURA 35 - Gráfico do Treinamento da Rede - sensor 1 
A seguir a FIGURA 36 mostra a comparação entre a saída da rede e o alvo (Treinamento), e a FIGURA 37 mostra a comparação entre a saída e o alvo (teste).

Na TABELA 3 têm-se os valores da constante de tempo desejados (alvo) e a constante de tempo dada pela RNA.

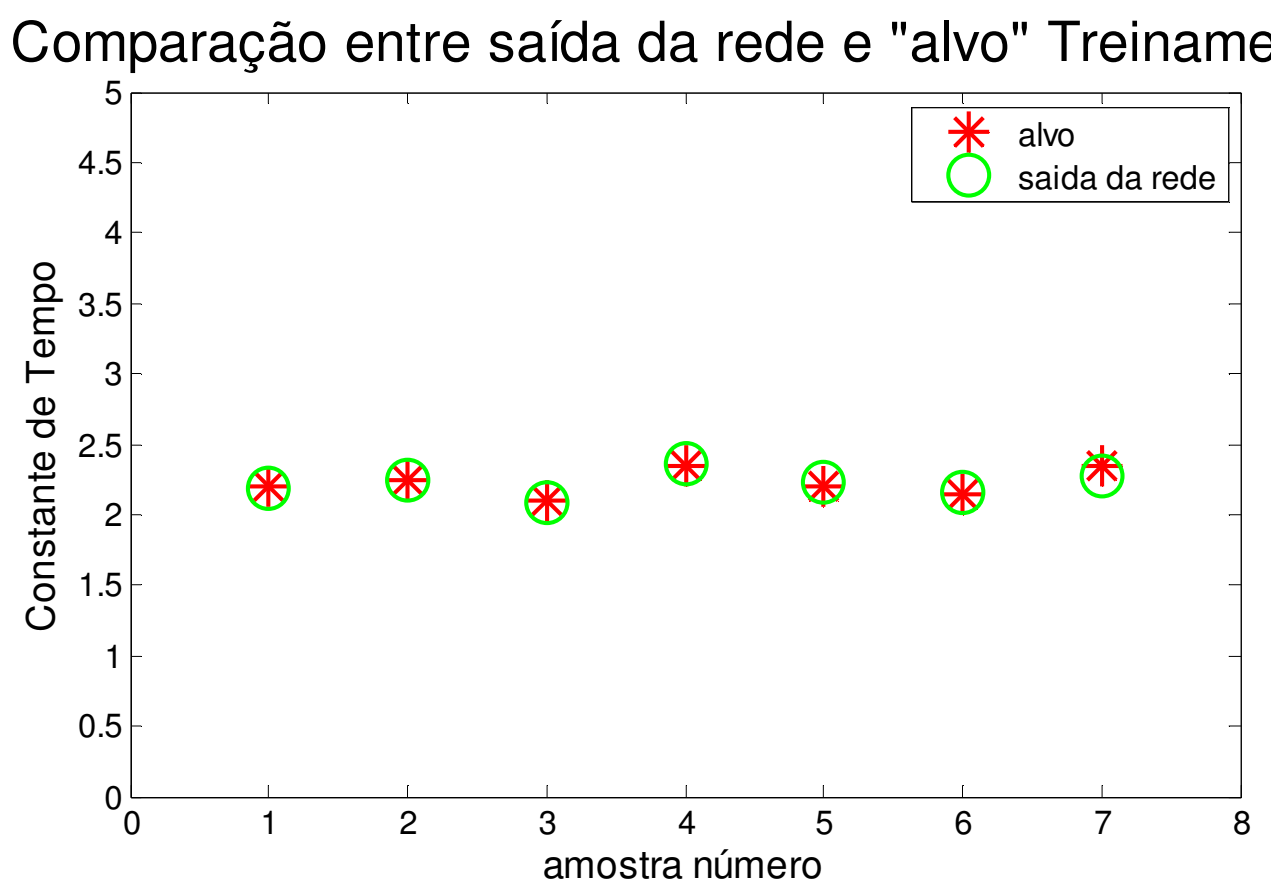

FIGURA 36 - Gráfico de comparação entre saída da rede e alvo (Treinamento sensor1).

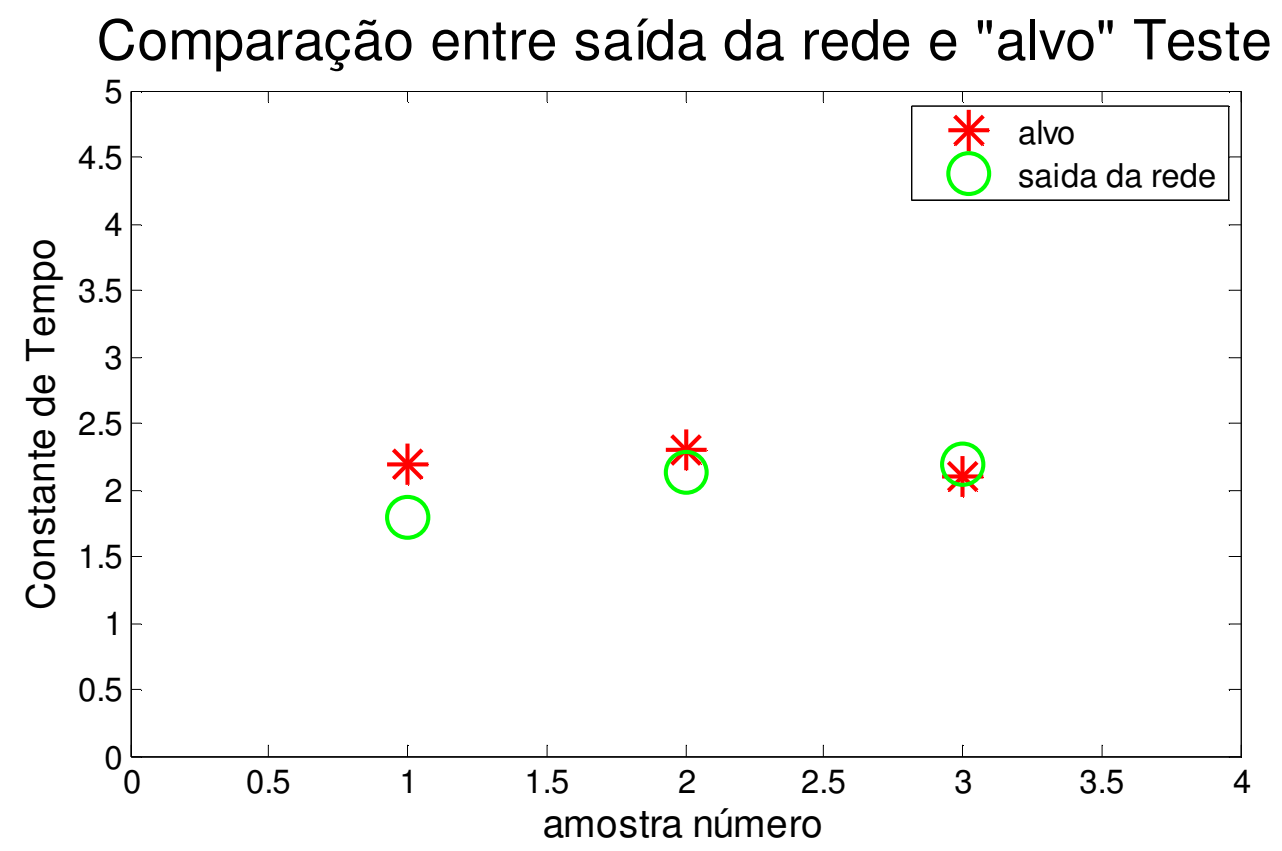

FIGURA 37 - Gráfico de comparação entre saída da rede e alvo (Teste sensor 1). 
TABELA 3 - Resultados Sensor 1

\begin{tabular}{|c|c|c|c|c|}
\hline & Curva & $\begin{array}{l}\text { Constante de } \\
\text { tempo Esperado } \\
\text { (Alvo) } \\
\text { (s) }\end{array}$ & $\begin{array}{l}\text { Constante de } \\
\text { tempo RNA } \\
\text { (Saída) } \\
\text { (s) }\end{array}$ & $\begin{array}{c}\text { Erro Quadrático } \\
\text { (MSE) }\end{array}$ \\
\hline \multirow{7}{*}{ TREINAMENTO } & 1 & 2,20 & 2,2504 & \multirow{7}{*}{7,4339 e -4} \\
\hline & 2 & 2,25 & 2,2392 & \\
\hline & 3 & 2,10 & 2,1182 & \\
\hline & 4 & 2,35 & 2,3271 & \\
\hline & 5 & 2,20 & 2,2155 & \\
\hline & 6 & 2,15 & 2,1150 & \\
\hline & 7 & 2,35 & 2,3352 & \\
\hline \multirow{4}{*}{ TESTE } & & & & \\
\hline & 8 & 2,20 & 2,2185 & \multirow{3}{*}{0,0467} \\
\hline & 9 & 2,30 & 2,2681 & \\
\hline & 10 & 2,10 & 2,4726 & \\
\hline
\end{tabular}

\section{3. - RNA com dados normalizados do Sensor 1}

Observando-se a FIGURA 38 pode-se verificar que há uma pequena variação da amplitude dos sinais resultantes dos testes LCSR realizados no sensor 1. Como a amplitude do sinal não é de interesse no teste LCSR e sim o comportamento dinâmico, foi elaborada uma nova rede neural com a finalidade de estudar o efeito de normalização dos dados de entrada. Foram utilizados os mesmos dados gerados para o Sensor 1, neste caso normalizamos a amplitude dos dados de entrada (valor máximo $=1$ ) para observar o comportamento da rede.

Embora esta variação seja pequena, pois os dados foram obtidos no laboratório, sabe-se que os dados obtidos em testes realizados na Usina de Angra I podem apresentar variações maiores. 


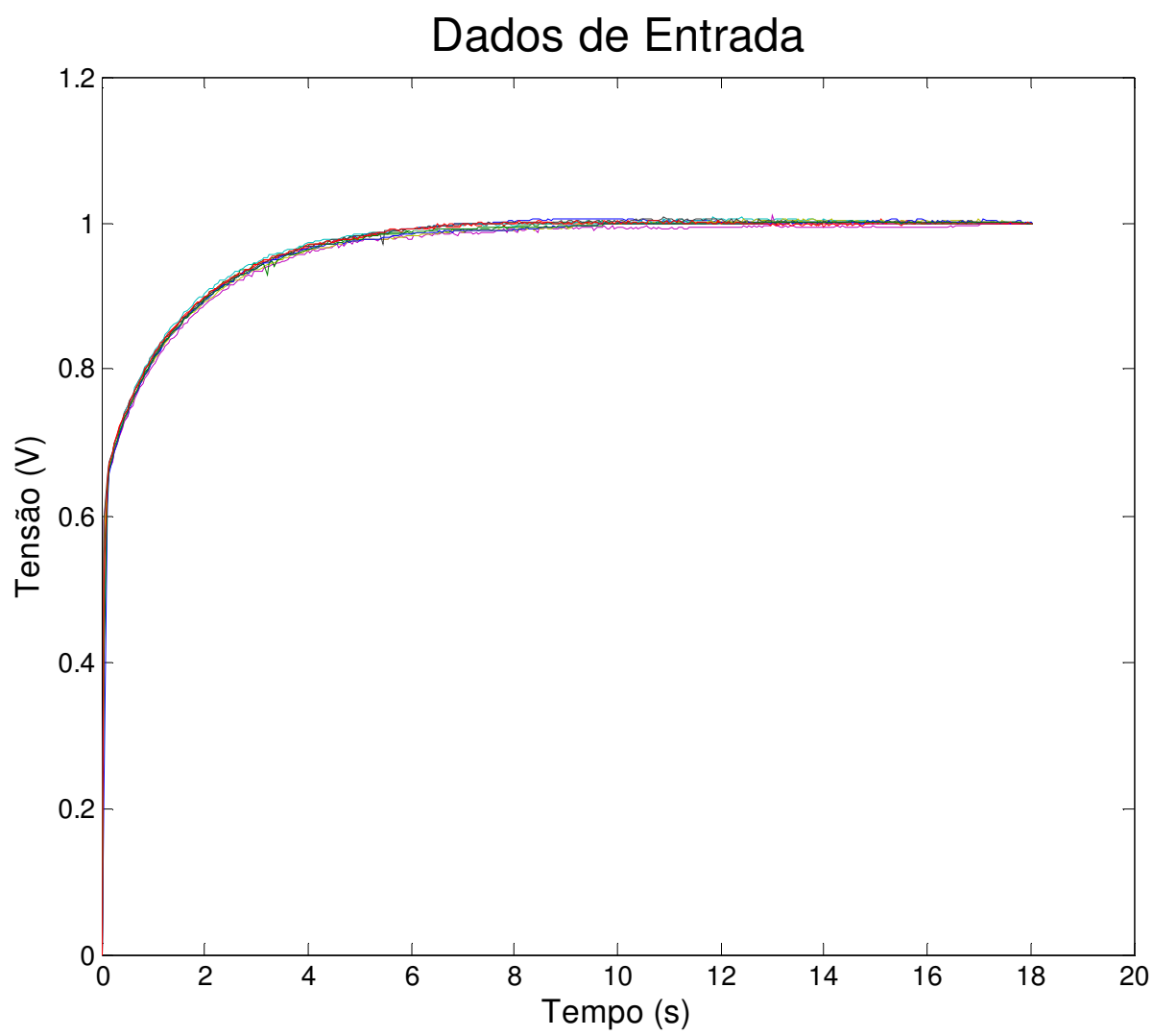

FIGURA 38 - Dados de entrada da rede do sensor1.

Esta rede também foi modelada com 1 camada de entrada, 1 camada oculta com 3 neurônios e uma camada de saída, tendo 10 sinais de entrada e 10 sinais de saída, com treinamento de 100 épocas e com um erro aceito em 0,001 .

Nesta rede foi usado o mesmo número de pontos e a mesma quantidade de curvas do sensor 1 anterior. Para esta RNA também foi usado $70 \%$ dos dados para treinamento e 30\% para teste. A seguir na FIGURA 39 tem-se Gráfico mostrando dados de saída e na FIGURA 40 tem-se o comportamento no treinamento da Rede. 


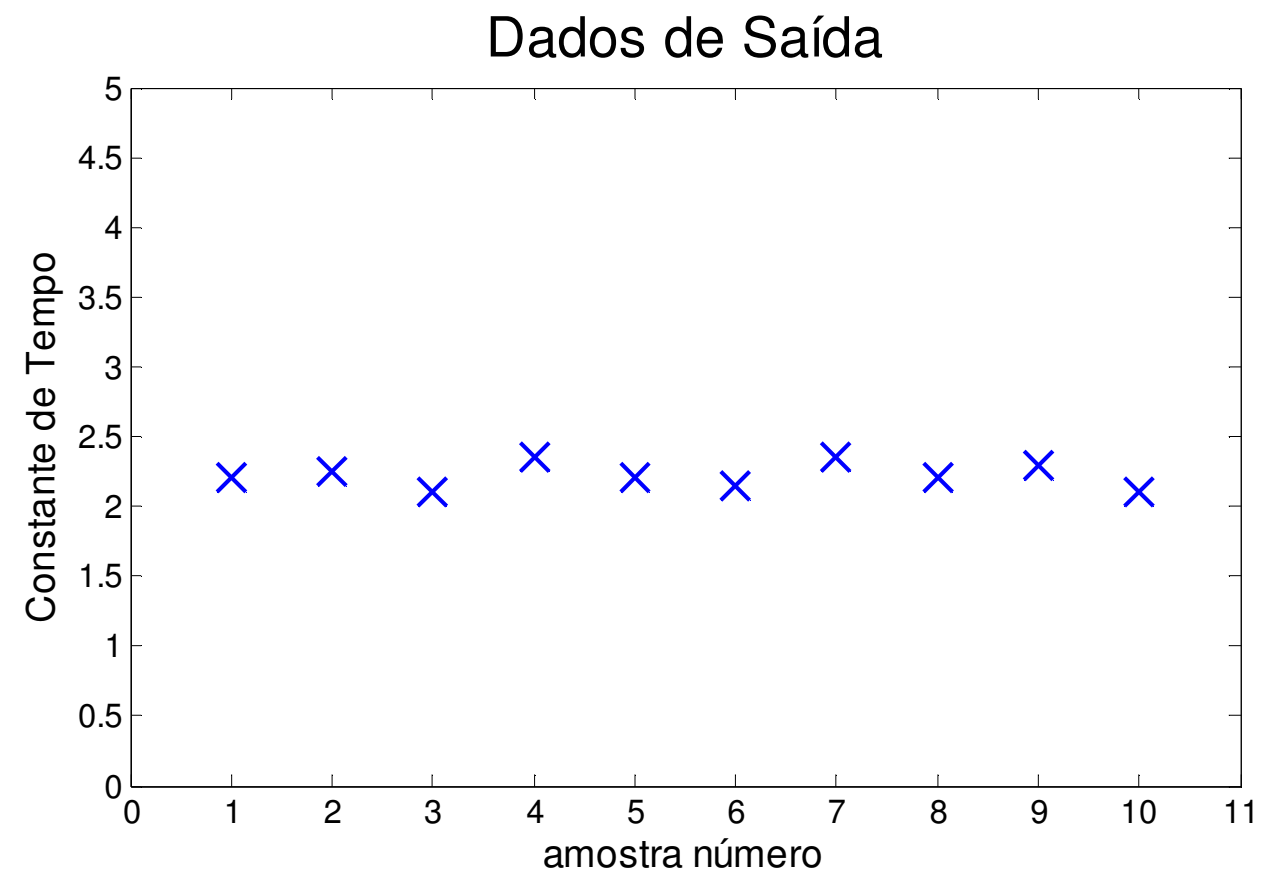

FIGURA 39 - Dados de Saída da Rede sensor 1.

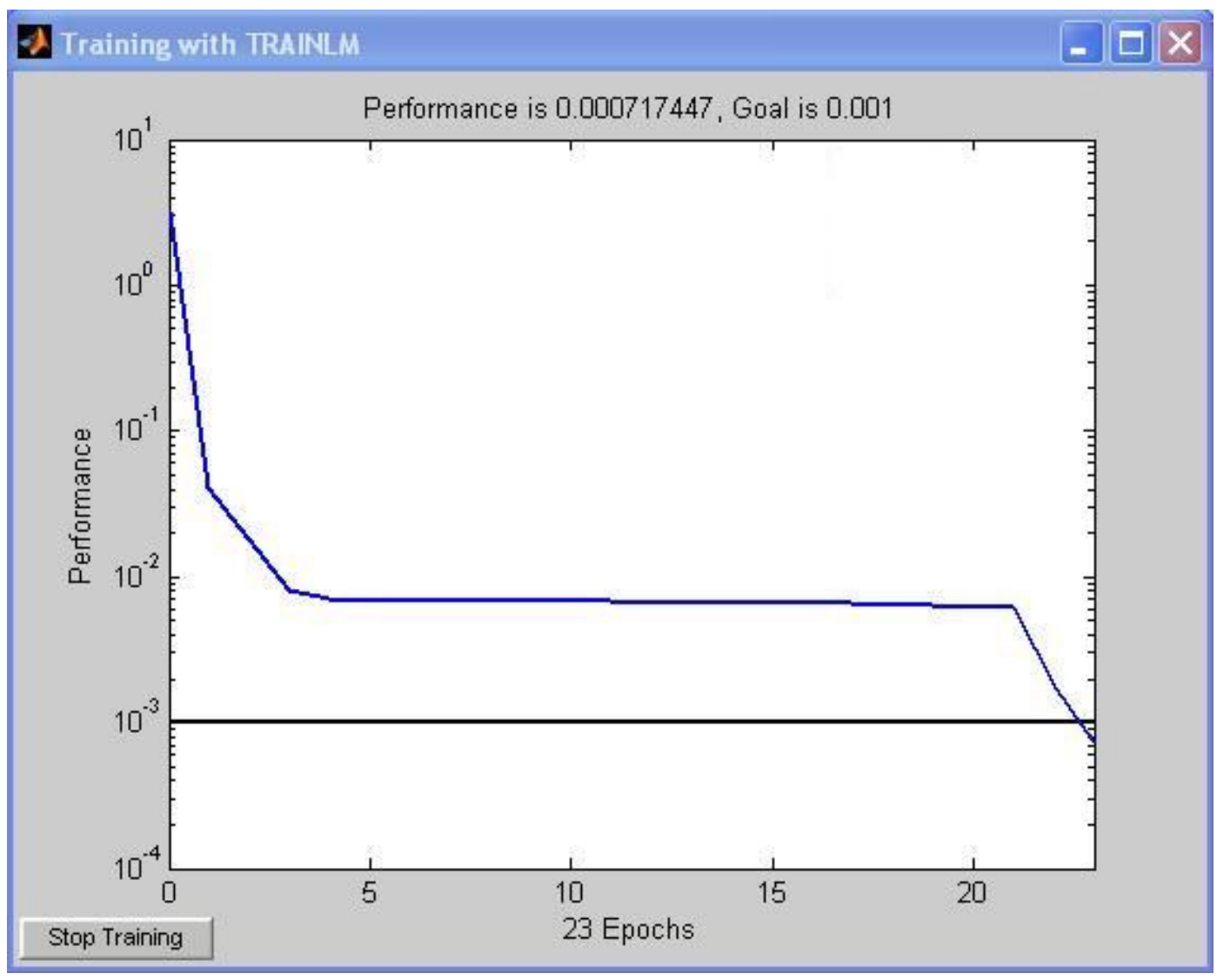

FIGURA 40 - Gráfico do Treinamento da Rede - sensor 1. 
A seguir a FIGURA 41 mostra o Gráfico com a comparação entre a saída da rede e o alvo (Treinamento). A FIGURA 42 mostra o gráfico com a comparação entre saída da rede e o alvo (teste).

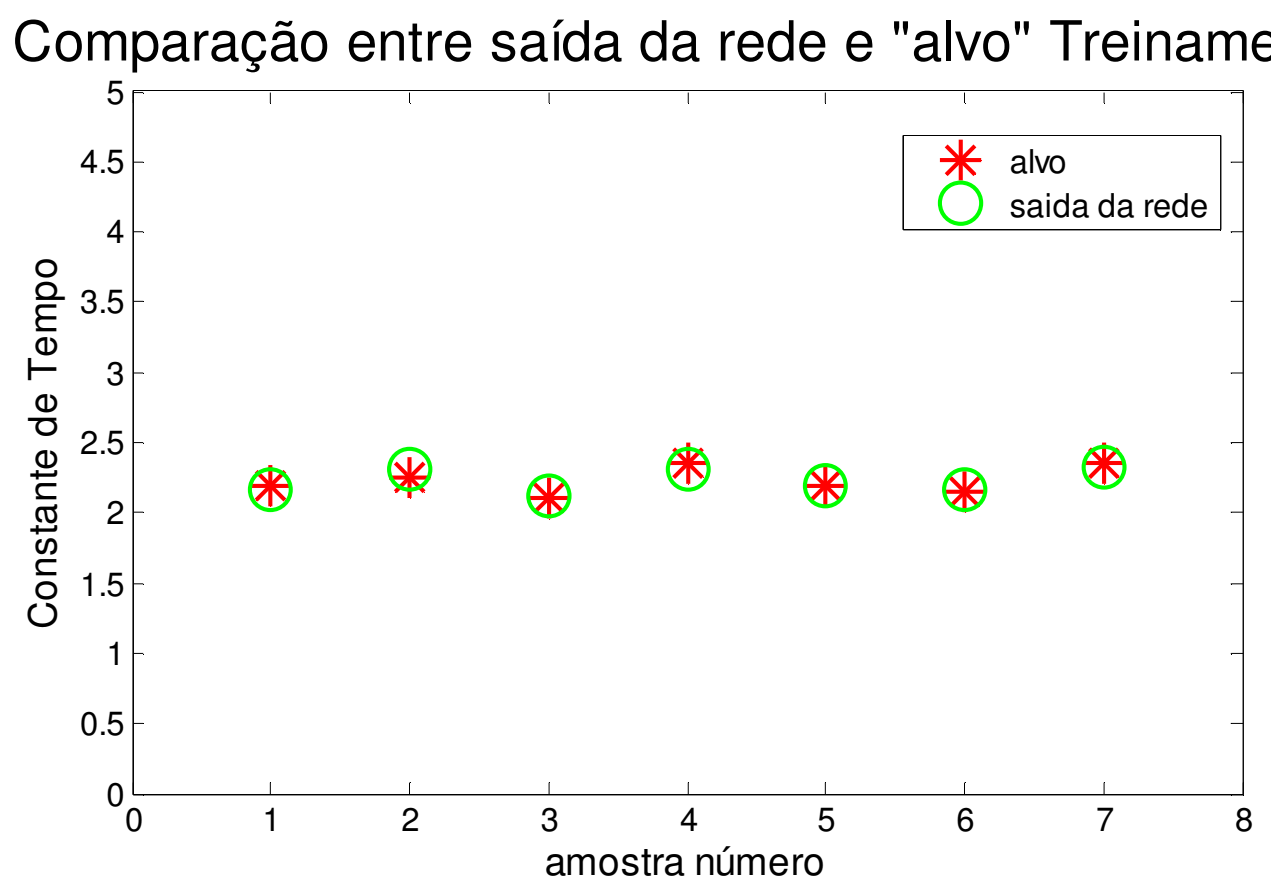

FIGURA 41 - Gráfico de comparação entre saída da rede e alvo (Treinamento sensor1).

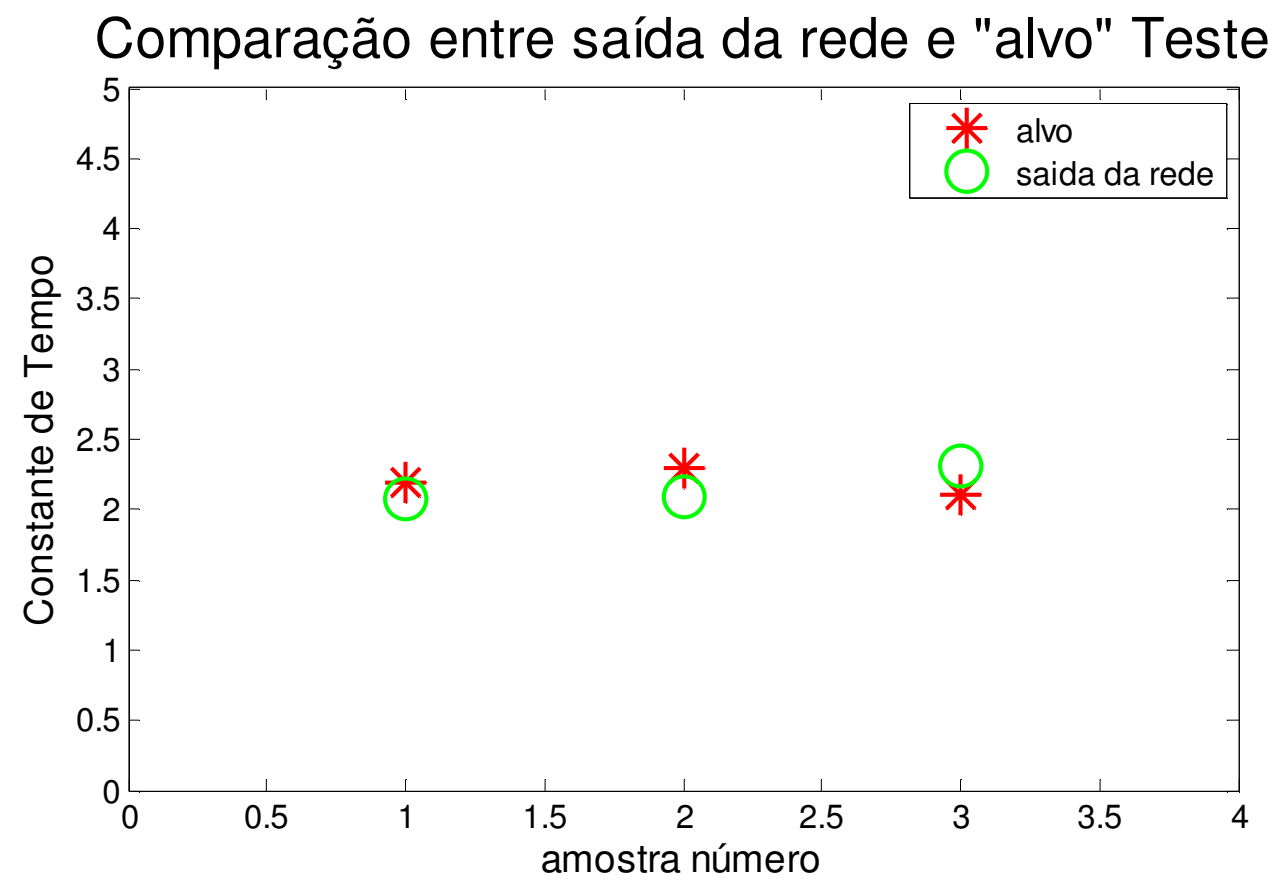

FIGURA 42 - Gráfico de comparação entre saída da rede e alvo de Teste sensor 1 
TABELA 4 - Resultados do Sensor 1

\begin{tabular}{|c|c|c|c|c|}
\hline & Curva & $\begin{array}{l}\text { Constante } \\
\text { tempo } \\
\text { Esperado } \\
\text { (Alvo) }\end{array}$ & $\begin{array}{c}\text { Constante de } \\
\text { tempo RNA } \\
\text { (Saída) }\end{array}$ & $\begin{array}{c}\text { Erro } \\
\text { Quadrático } \\
\text { (MSE) }\end{array}$ \\
\hline \multirow{7}{*}{ TREINAMENTO } & 1 & 2,20 & 2,1811 & \multirow{7}{*}{7,1745 e -4} \\
\hline & 2 & 2,25 & 2,2432 & \\
\hline & 3 & 2,10 & 2,0815 & \\
\hline & 4 & 2,35 & 2,3482 & \\
\hline & 5 & 2,20 & 2,1359 & \\
\hline & 6 & 2,15 & 2,1405 & \\
\hline & 7 & 2,35 & 2,3413 & \\
\hline & & & & \\
\hline \multirow{3}{*}{ TESTE } & 8 & 2,20 & 2,1147 & \multirow{3}{*}{$\mathbf{0 , 0 0 3 0}$} \\
\hline & 9 & 2,30 & 2,1118 & \\
\hline & 10 & 2,10 & 2,1481 & \\
\hline
\end{tabular}

Analisando as FIGURAS 41 e 42 e as TABELAS 3 e 4, podemos observar que embora o desempenho de treinamento tenha sido muito próximo ao anterior, sem a normalização os resultados dos testes foram melhores. Sendo assim mantivemos o uso da normalização para as demais redes.

\section{4. - RNA com dados do Sensor 2}

O sensor 2 também é um RTD PT-100 e tem 6,35 mm de diâmetro externo e 305 $\mathrm{mm}$ de comprimento. Com estas características este sensor se mostrou mais lento que o anterior.

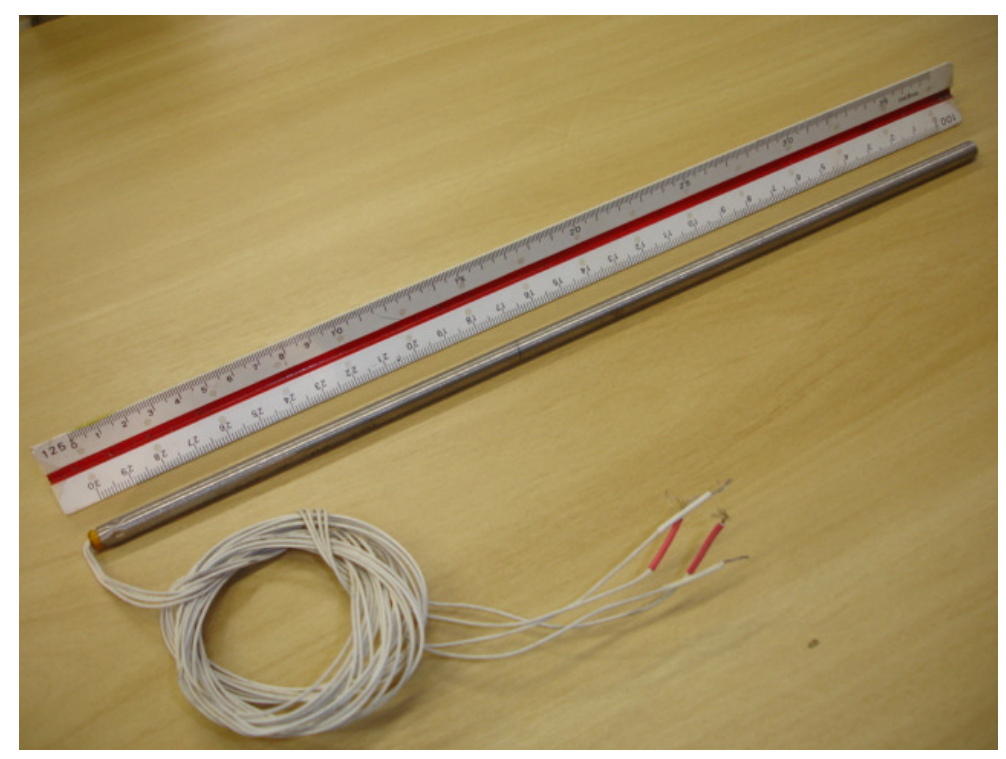

FIGURA 43 - Sensor 2 
Os testes foram realizados todos nas mesmas condições de temperatura ambiente e temperatura do banho térmico.

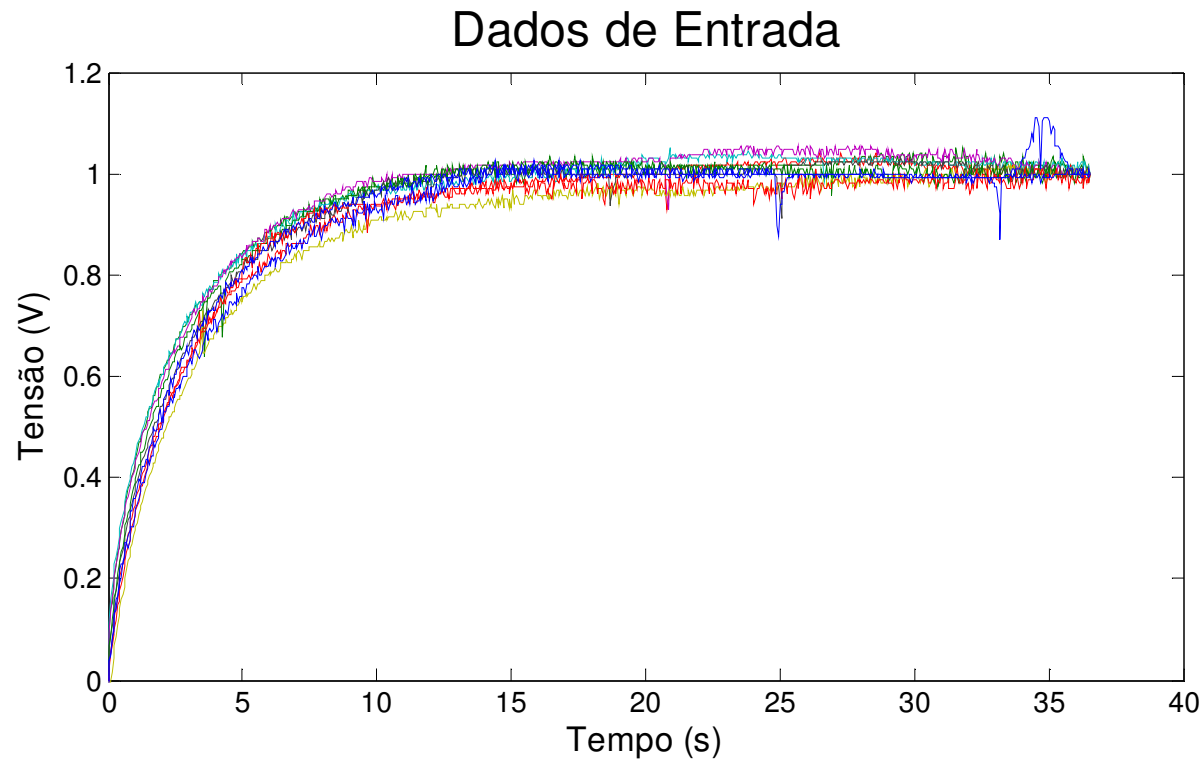

FIGURA 44 - Dados de entrada da rede do sensor2.

Esta rede também foi modelada com 1 camada de entrada, 1 camada oculta com 3 neurônios e uma camada de saída, tendo 10 sinais de entrada e 10 sinais de saída e com treinamento máximo de 100 épocas e com um erro máximo aceito em 0,001. Destes sinais $70 \%$ foram usados para treinamento e $30 \%$ para teste na RNA.

Este sensor é mais lento que o anterior, com isto o tempo de aquisição foi maior gerando um maior número de pontos para os dados de entrada da rede. A configuração dos sinais de entrada (camada de entrada) da rede ficou com 10 curvas tendo 732 pontos cada curva, e a constante de tempo do sensor formou a camada de saída (alvo). Para a entrada de treinamento da rede foram usadas as colunas de 1 a 7 dos sinais de entrada e como saída (alvo) as colunas 1 a 7 dos dados da constante de tempo. Para entrada teste foram usadas as colunas 8 a 10 dos dados de entrada, e saída teste 8 a 10 da constante de tempo. A seguir na FIGURA 45 tem-se o Gráfico mostrando dados de saída e na FIGURA 46 tem-se o comportamento no treinamento da Rede, onde se pode observar que com 29 épocas a RNA atingiu o resultado desejado. 


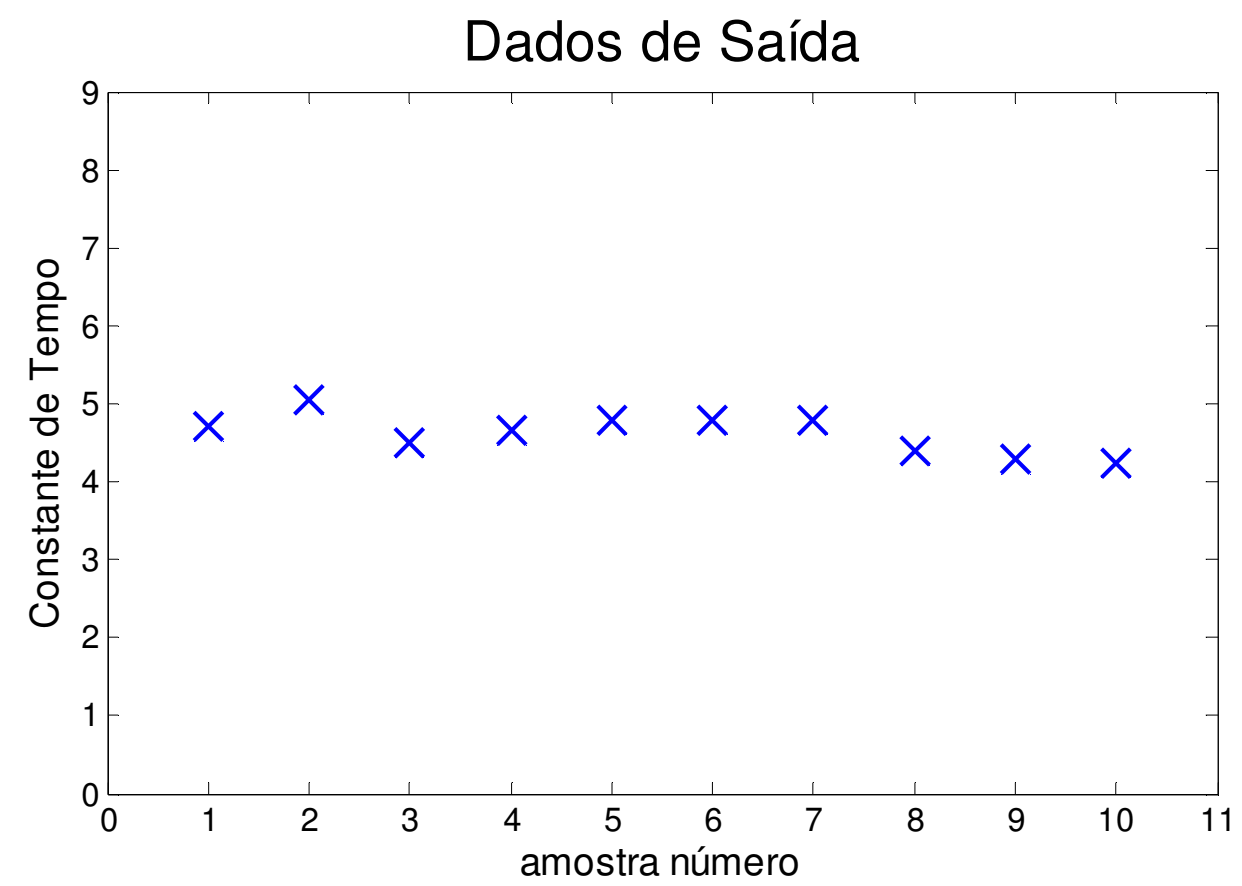

FIGURA 45 - Dados de Saída da Rede sensor 2.

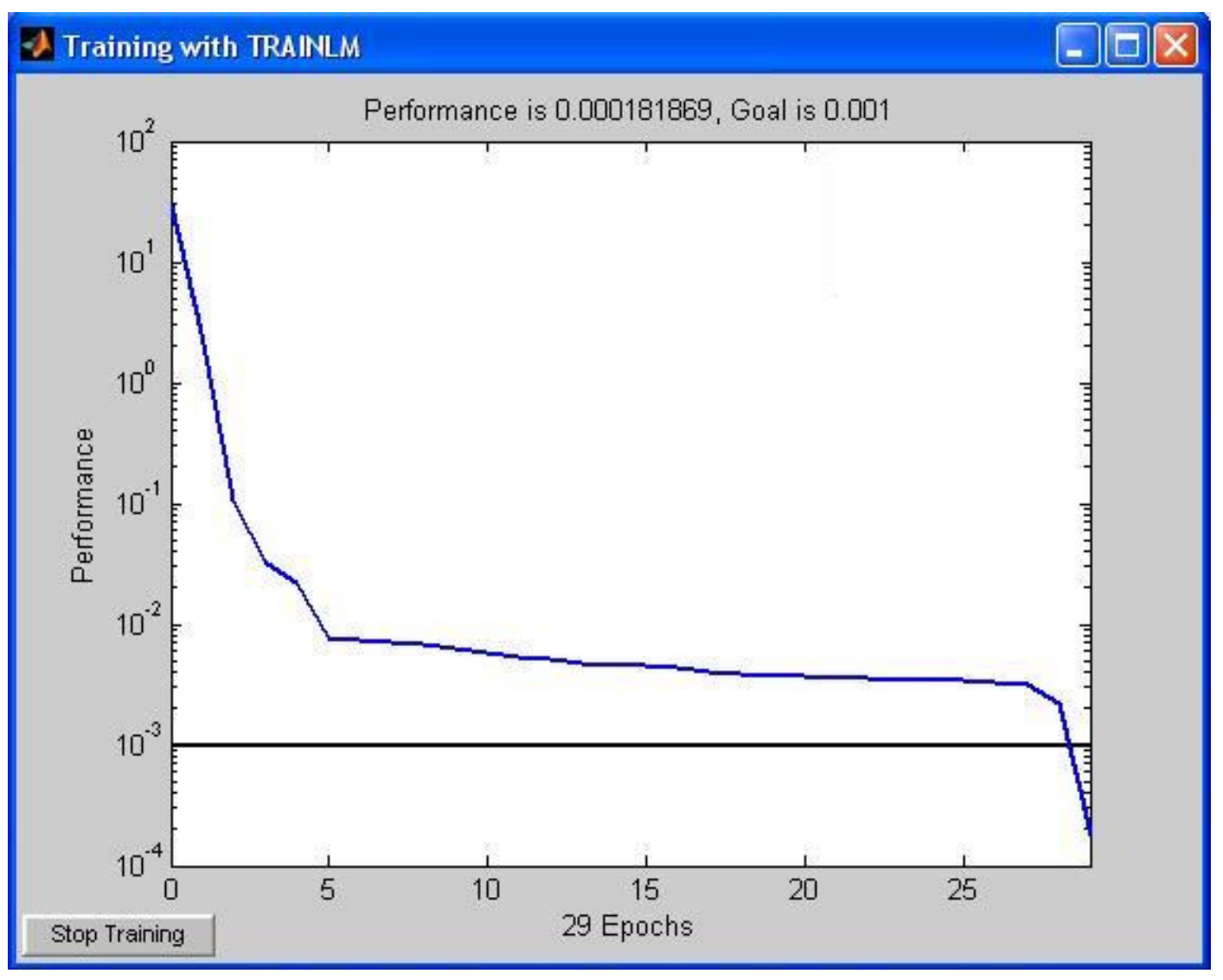

FIGURA 46 - Gráfico do Treinamento da Rede - sensor 2. 
A seguir as FIGURAs 47 e 48 mostram a comparação entre a saída da rede e o alvo (Treinamento e Teste) e a TABELA 5 mostra os resultados para o sensor 2.

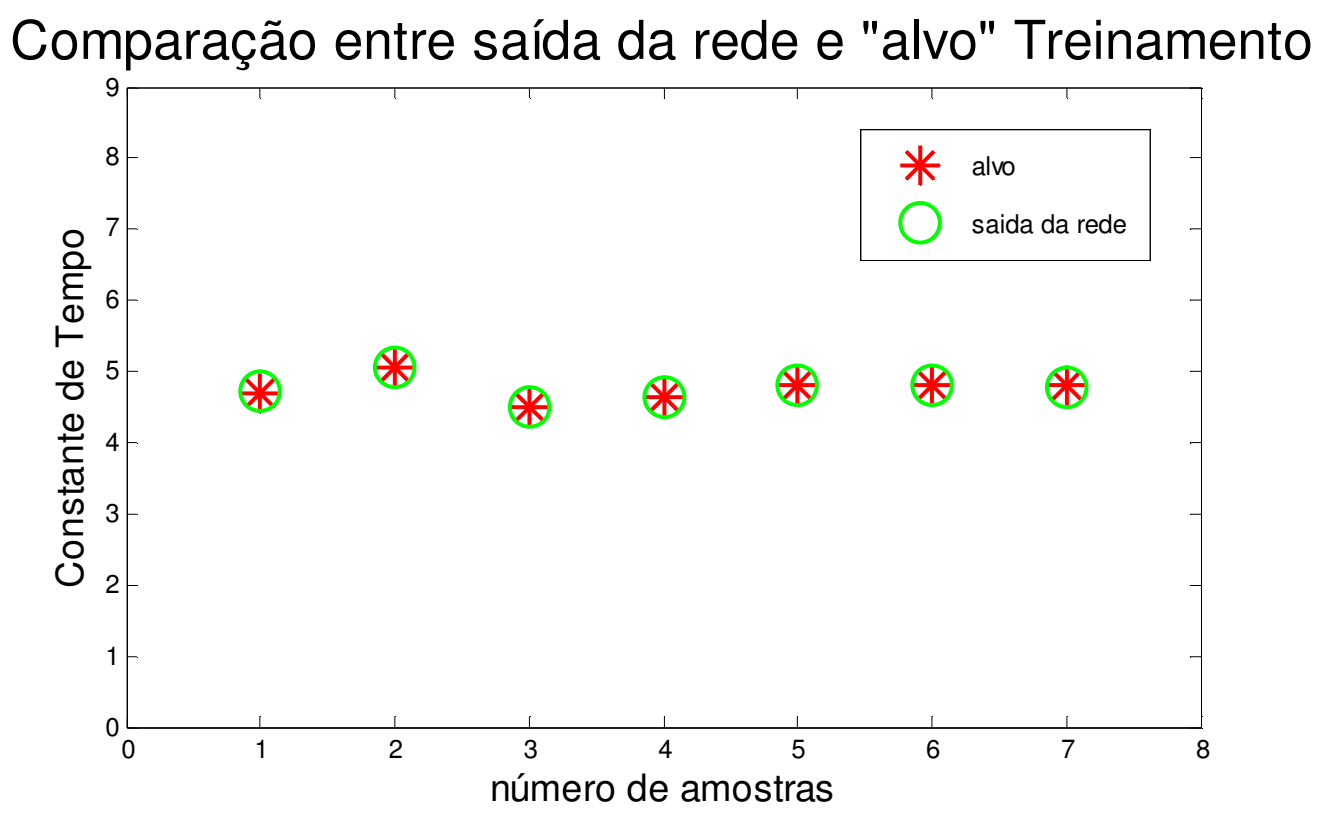

FIGURA 47 - Gráfico de comparação entre saída da rede e alvo (Treinamento sensor 2).

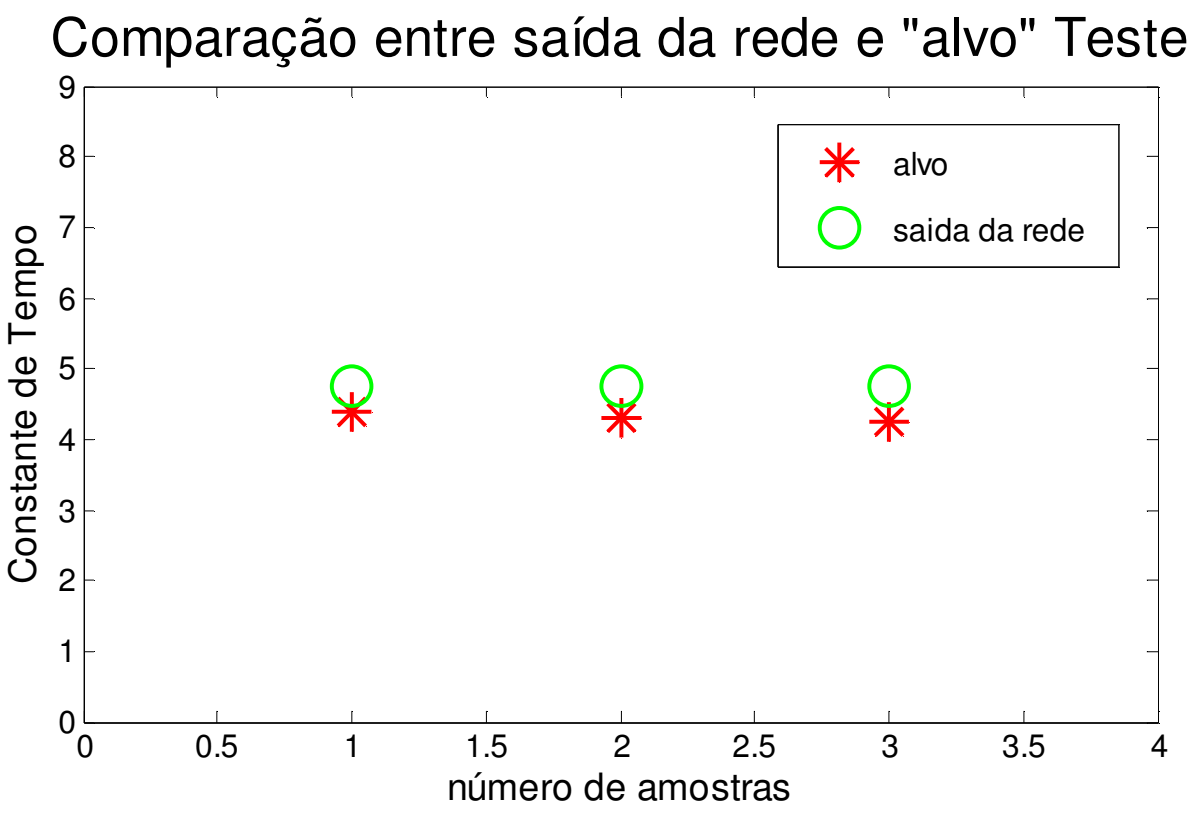

FIGURA 48 - Gráfico de comparação entre saída da rede e alvo (Teste sensor 2). 
TABELA 5 - Resultados do Sensor 2

\begin{tabular}{|c|c|c|c|c|}
\hline & Curva & $\begin{array}{c}\text { Contante de } \\
\text { tempo } \\
\text { Esperado } \\
\text { (Alvo) } \\
\text { (s) }\end{array}$ & $\begin{array}{l}\text { Constante } \\
\text { de tempo } \\
\text { RNA } \\
\text { (Saída) } \\
\text { (s) }\end{array}$ & $\begin{array}{c}\text { Erro } \\
\text { Quadrático } \\
\text { (MSE) }\end{array}$ \\
\hline \multirow{7}{*}{ TREINAMENTO } & 1 & 4,70 & 4,6987 & \multirow{7}{*}{1,8187 e -4} \\
\hline & 2 & 5,05 & 5,0402 & \\
\hline & 3 & 4,50 & 4,5083 & \\
\hline & 4 & 4,65 & 4,6471 & \\
\hline & 5 & 4,80 & 4,7753 & \\
\hline & 6 & 4,80 & 4,7904 & \\
\hline & 7 & 4,80 & 4,8199 & \\
\hline & & & & \\
\hline \multirow{3}{*}{ TESTE } & 8 & 4,40 & 4,8060 & \multirow{3}{*}{0,4298} \\
\hline & 9 & 4,30 & 4,7806 & \\
\hline & 10 & 4,25 & 5,1953 & \\
\hline
\end{tabular}

\section{5. - RNA com dados do Sensor 3}

Com a finalidade de testar diferentes sensores, foi colocada uma capa de metal no sensor 1. Desta forma fica alterada sua resistência de transferência de calor para o meio e consequentemente o seu tempo de resposta aumenta, simulando um terceiro sensor, chamado sensor 3. Esta capa colocada no sensor 1 tem 4,77 $\mathrm{mm}$ de diâmetro externo, 3,28 mm de diâmetro interno e um comprimento de 152,37 mm. A FIGURA 49 mostra o sensor 1 e a capa de metal (inox).

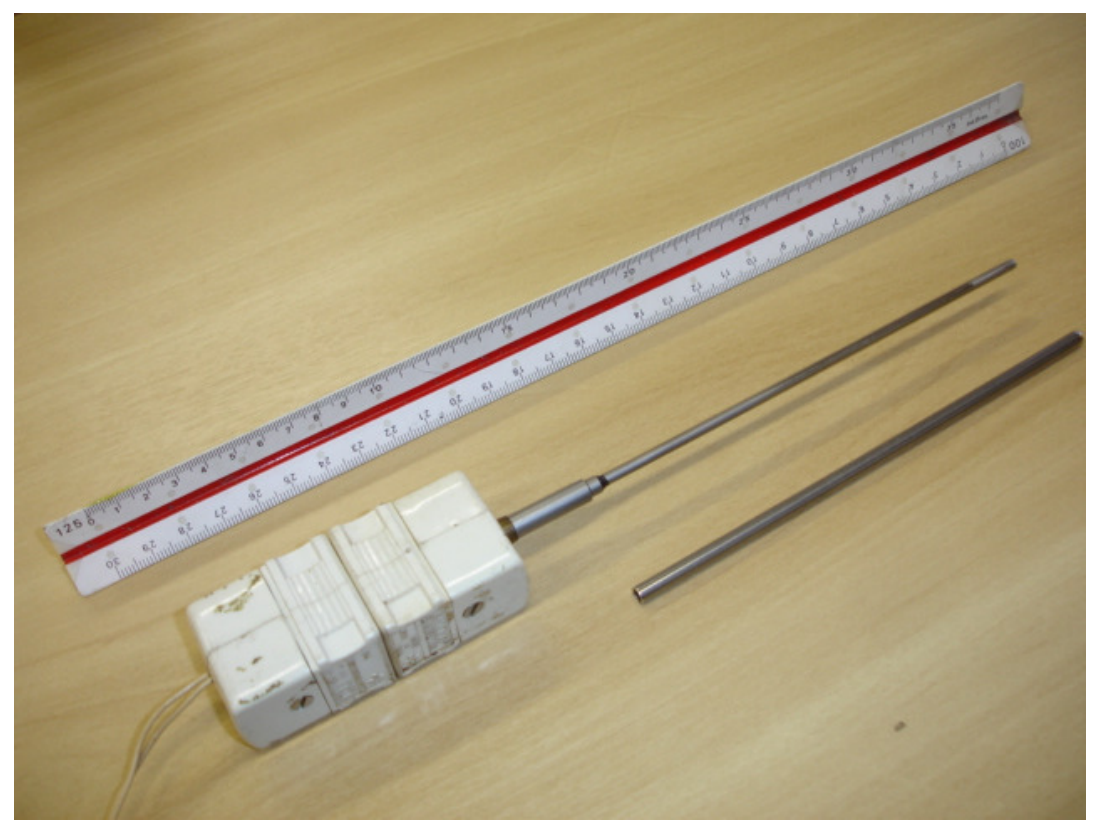

FIGURA 49 - Sensor 3. 


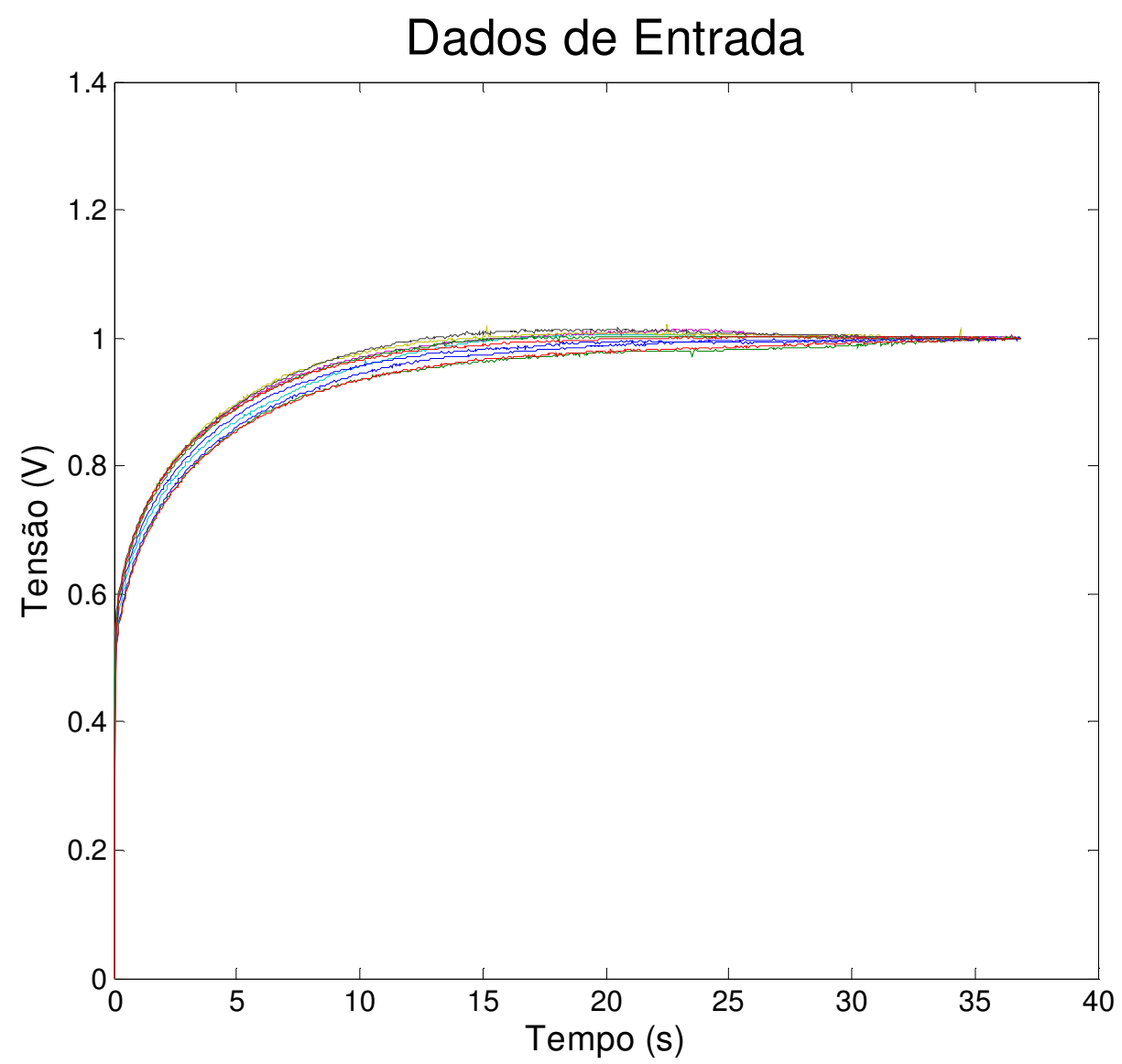

FIGURA 50 - Dados de entrada da rede do sensor 3.

Esta rede também foi modelada como as anteriores. Com o tempo de resposta mais lento consequentemente tivemos um maior número de pontos na curva deste sensor.

Então este sensor ficou com 10 curvas contendo 738 pontos cada uma delas, formando assim a camada de entrada da rede e a constante de tempo do sensor o alvo para a rede. Para a entrada de treinamento da rede foram usadas as curvas de 1 a 7 e como saída (alvo) as constantes de tempo correspondentes. Para entrada teste foram usados os pontos das curvas 8 a 10, e como saídas teste (alvo) foram usadas as constantes de tempo correspondentes. 


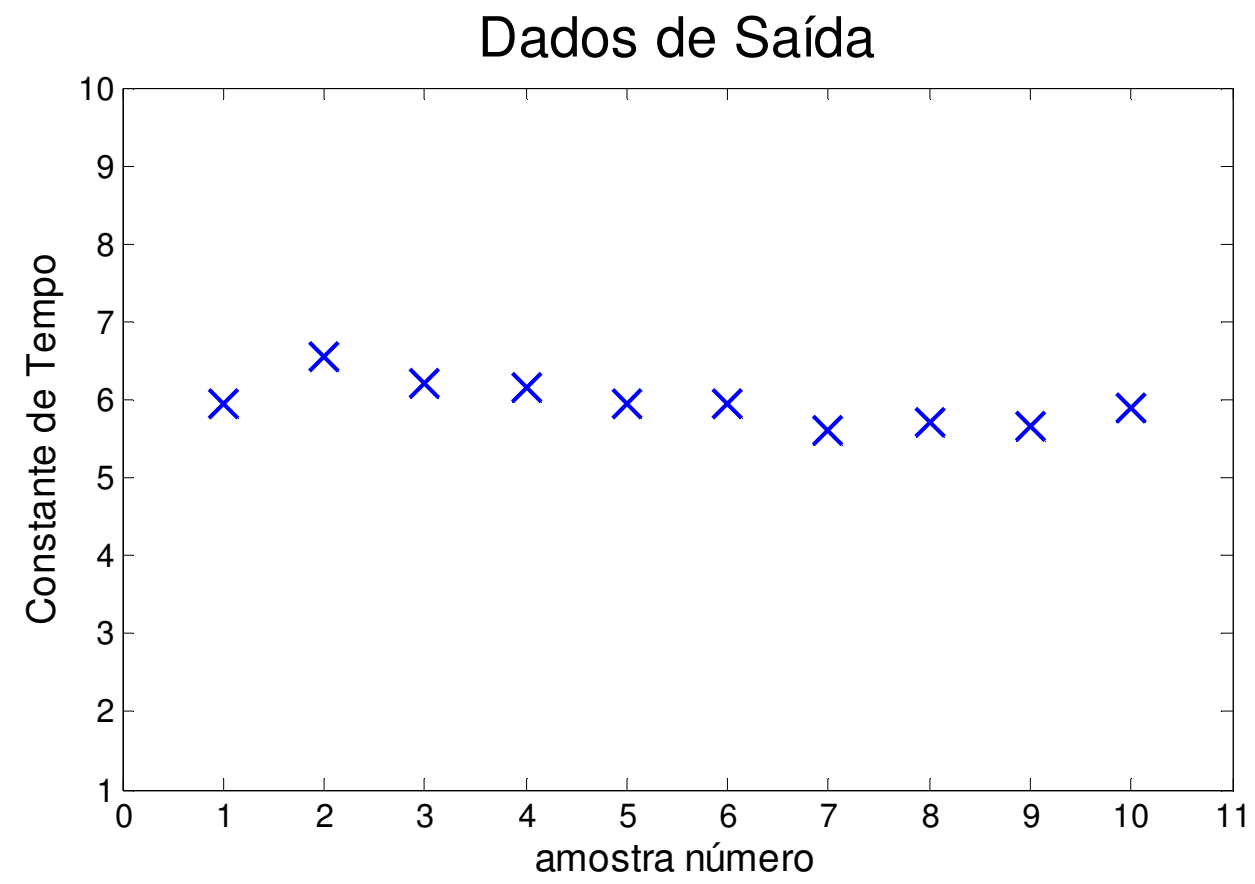

FIGURA 51 - Dados de Saída da Rede sensor 3.

A FIGURA 52 mostra o desempenho da rede para treinamento as FIGURAS 53 e 54 mostram a comparação entre o alvo e saída da rede para treinamento e teste, respectivamente.

Na TABELA 6 têm-se os resultados do sensor 3. 


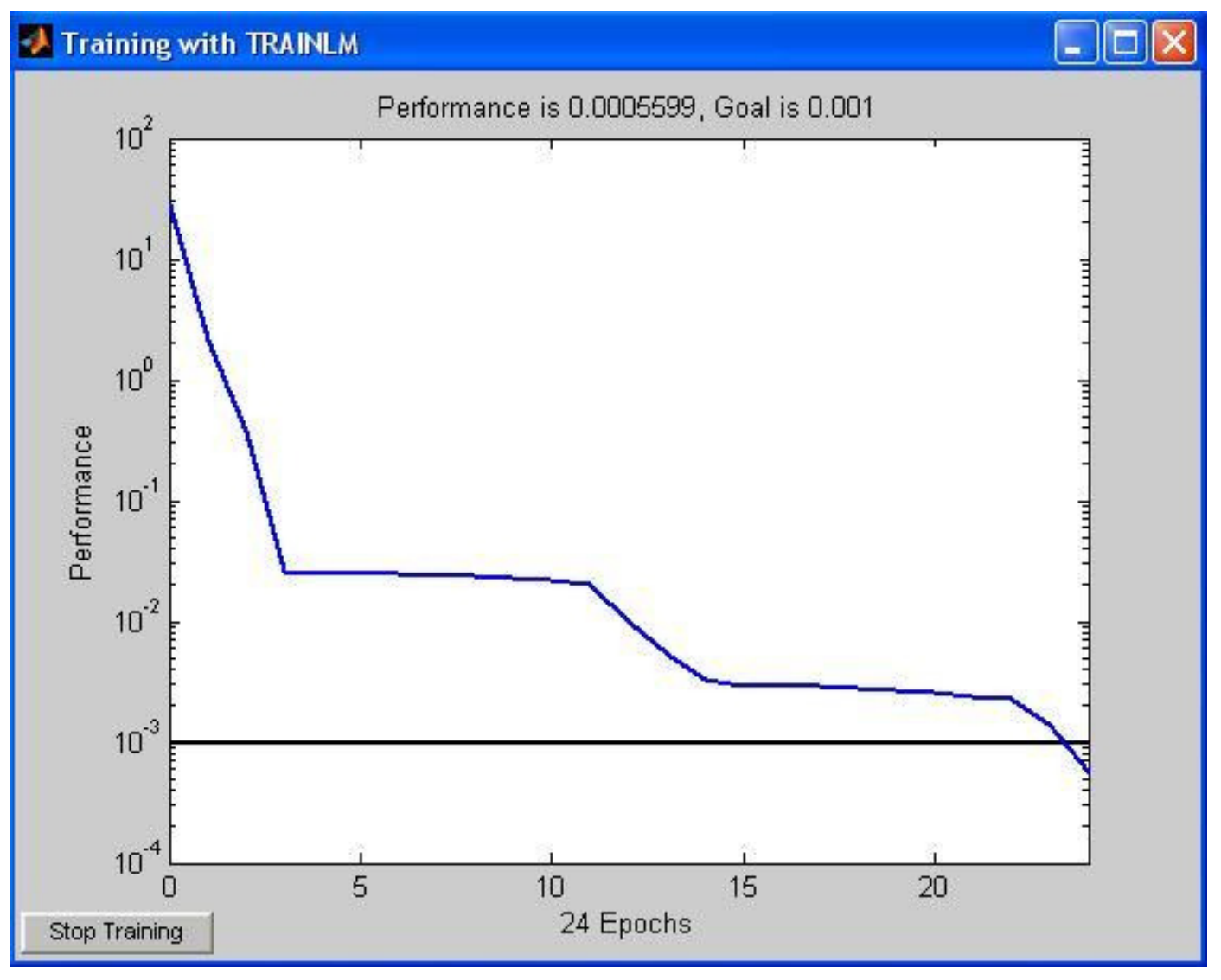

FIGURA 52 - Gráfico do Treinamento da Rede - sensor 3.

\section{Comparação entre saída da rede e "alvo" Treinamento}

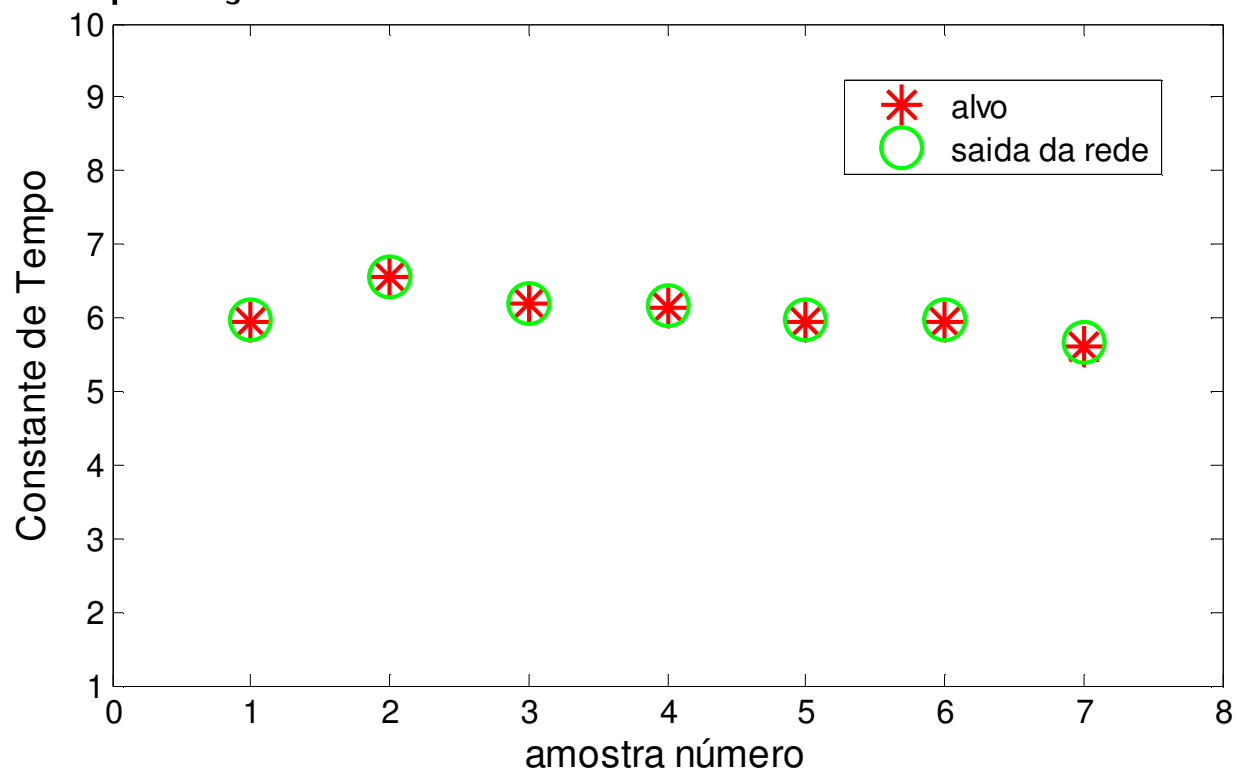

FIGURA 53 - Gráfico de comparação entre saída da rede e alvo (Treinamento sensor 3). 


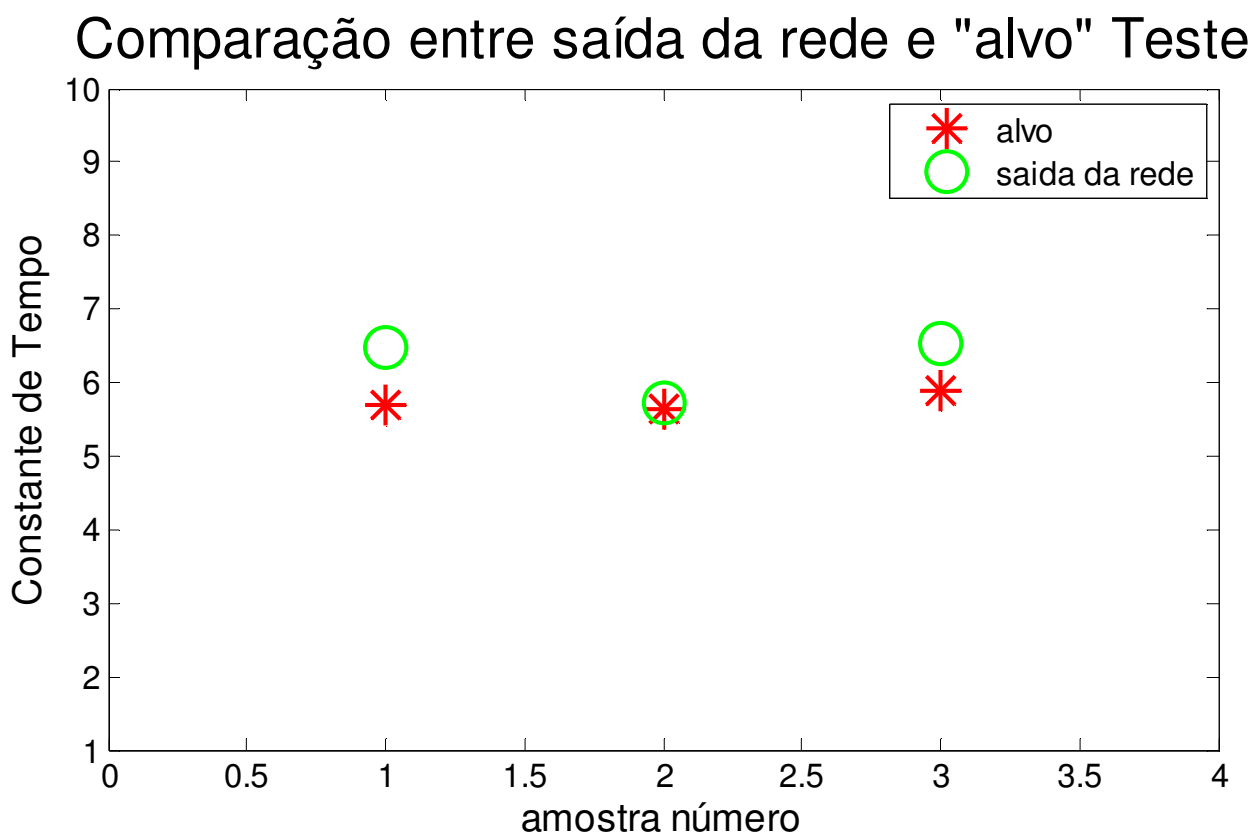

FIGURA 54 - Gráfico de comparação entre saída da rede e alvo (Teste sensor 3).

TABELA 6 - Resultados do Sensor 3

\begin{tabular}{|c|c|c|c|c|}
\hline & Curva & $\begin{array}{c}\text { Constante de } \\
\text { tempo } \\
\text { Esperado } \\
\text { (Alvo) }\end{array}$ & $\begin{array}{c}\text { Constante } \\
\text { de tempo } \\
\text { RNA (Saída) }\end{array}$ & $\begin{array}{c}\text { Erro } \\
\text { Quadrático } \\
\text { (MSE) }\end{array}$ \\
\hline \multirow{7}{*}{ TREINAMENTO } & 1 & 5,95 & 5,9679 & \multirow{7}{*}{5,5990 e -4} \\
\hline & 2 & 6,50 & 6,5467 & \\
\hline & 3 & 6,20 & 6,1725 & \\
\hline & 4 & 6,15 & 6,1063 & \\
\hline & 5 & 5,95 & 5,9575 & \\
\hline & 6 & 5,95 & 5,9772 & \\
\hline & 7 & 5,60 & 5,5886 & \\
\hline & & & & \\
\hline \multirow{3}{*}{ TESTE } & 8 & 5,70 & 6,0767 & \multirow{3}{*}{0,1151} \\
\hline & 9 & 5,65 & 6,0538 & \\
\hline & 10 & 5,90 & 6,1009 & \\
\hline
\end{tabular}

\section{6. - RNA utilizando os dados dos três Sensores}

Em vista dos resultados anteriores, foi feita uma nova RNA usando os três sensores. Esta rede também foi modelada como as anteriores, com 1 camada de entrada, 1 camada oculta com 3 neurônios e 1 camada de saída, tendo 10 sinais de entrada e 10 sinais de saída, com treinamento máximo de 100 épocas e com um erro máximo aceito em 0,001. 
Neste caso utilizamos também $70 \%$ dos dados para treinamento da RNA e $30 \%$ para teste. Como saída (alvo) da rede foi utilizada a constante de tempo de cada sensor. A FIGURA 54 mostra os dados de entrada normalizados de cada sensor e a FIGURA 56 mostra os dados de valor médio da constante de tempo de cada sensor.

Dados de Entrada

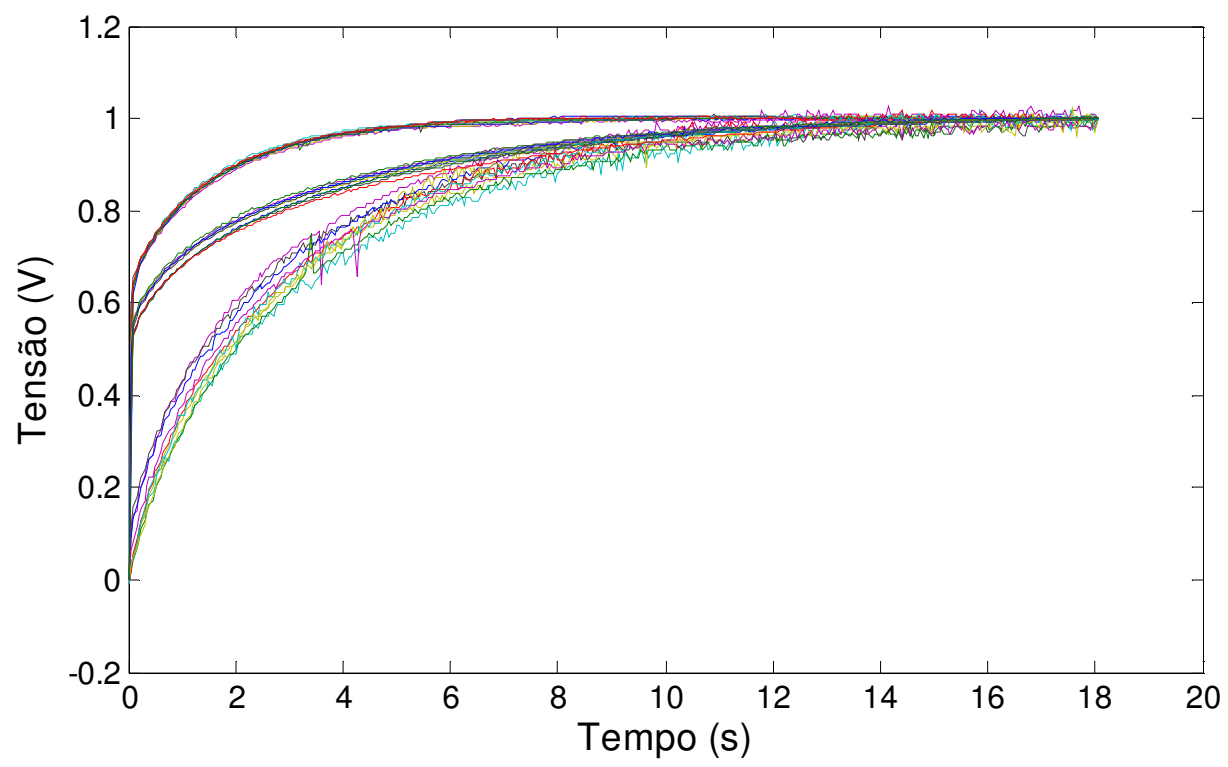

FIGURA 55 - Dados de entrada da rede dos sensores.

Dados de Saída

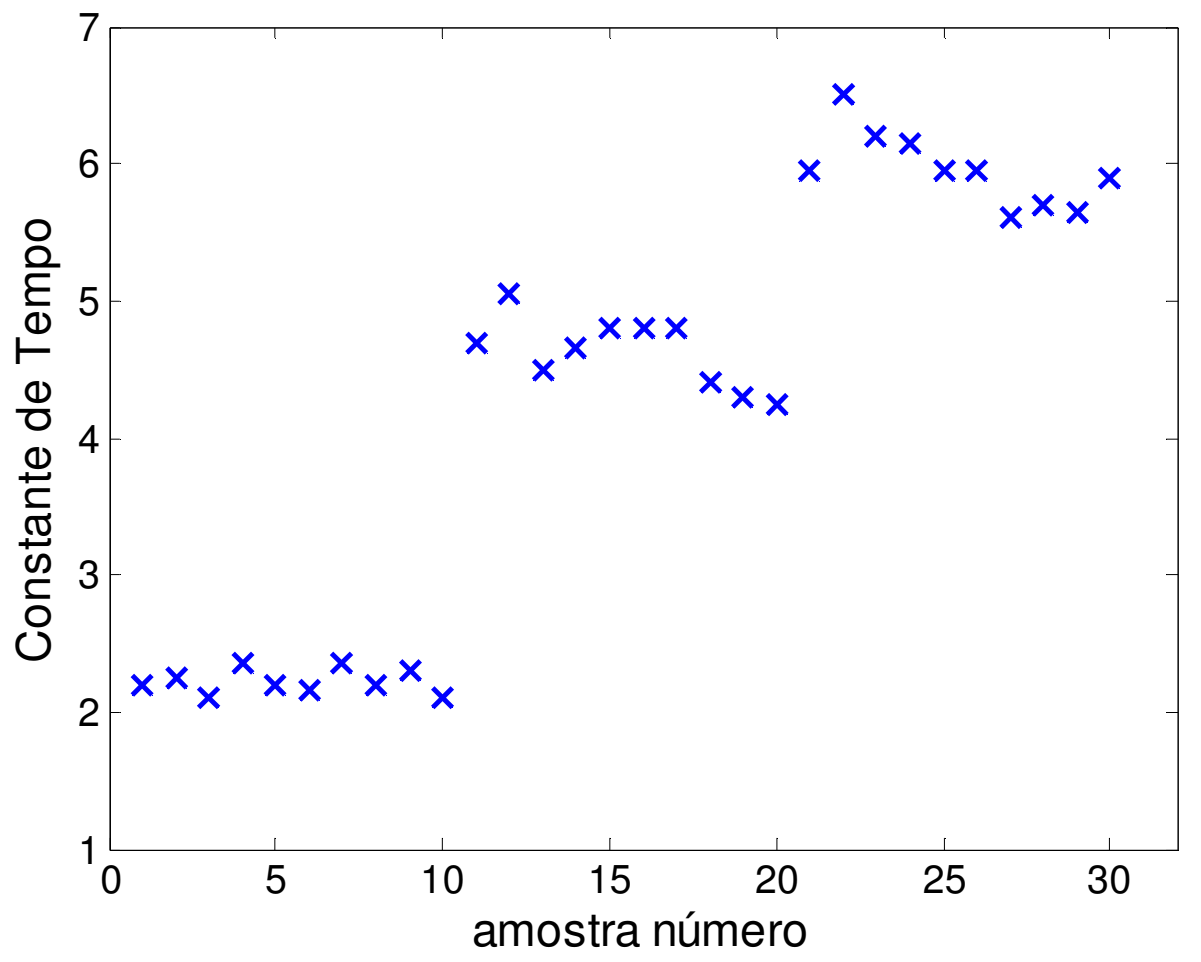

FIGURA 56 - Dados de Saída da Rede. 
Na FIGURA 56 tem-se o desempenho do treinamento da RNA e nas FIGURAS 57 e 58 tem-se a comparação entre a saída da rede e o alvo (treinamento) e a saída da rede e o alvo (teste).

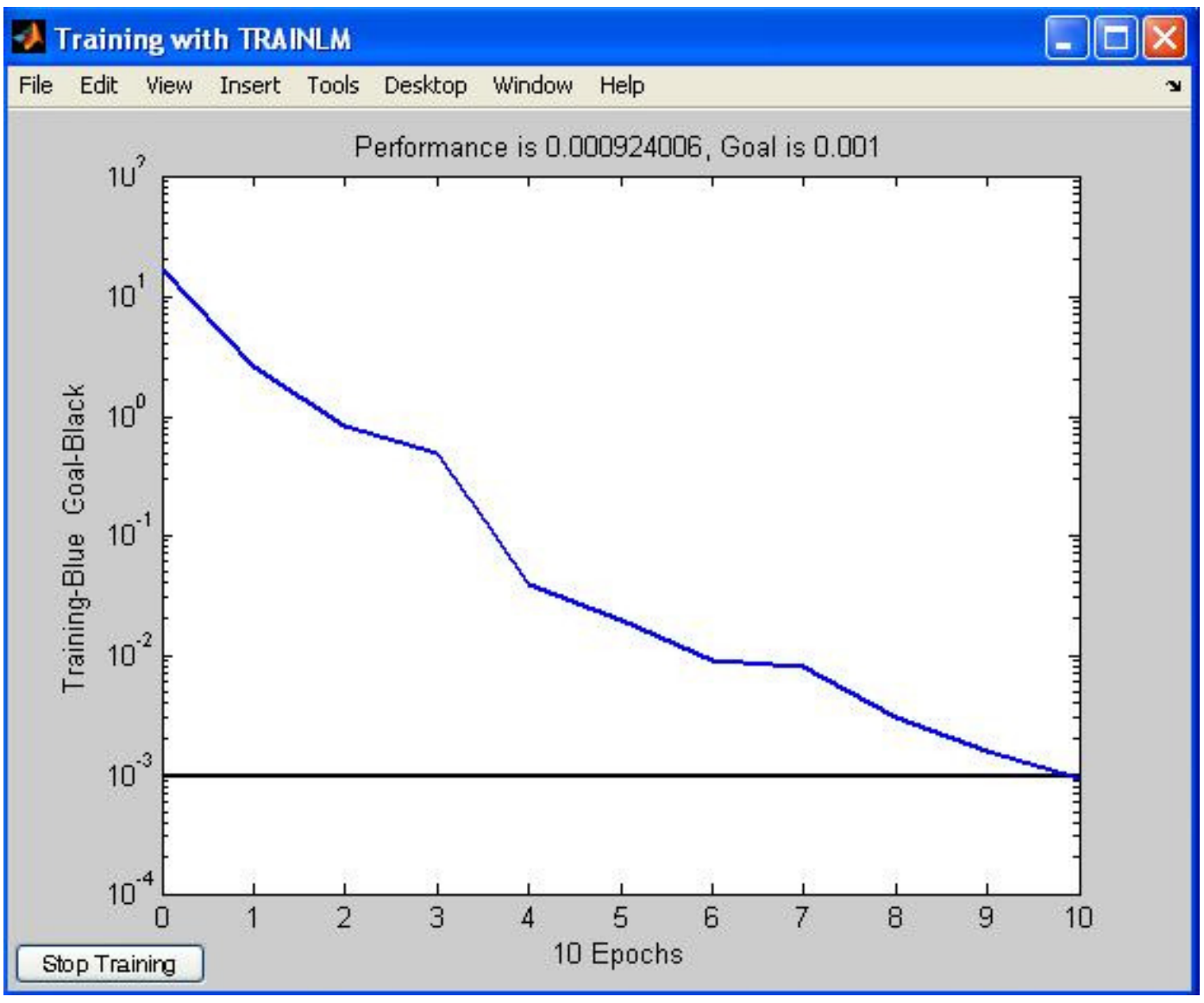

FIGURA 57 - Gráfico do Treinamento da Rede. 


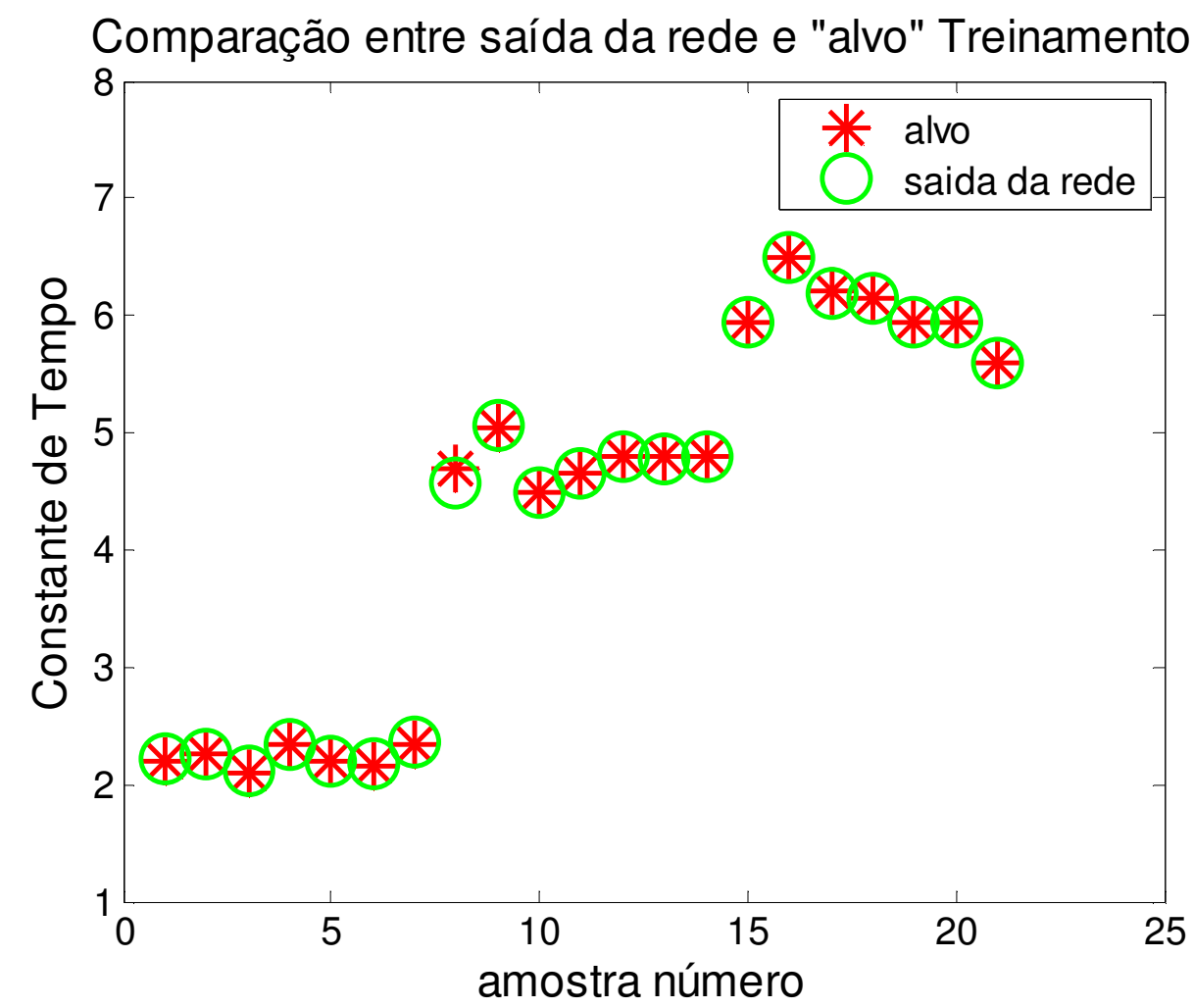

FIGURA 58 - Gráfico de comparação entre saída da rede e alvo (Treinamento sensor 3).

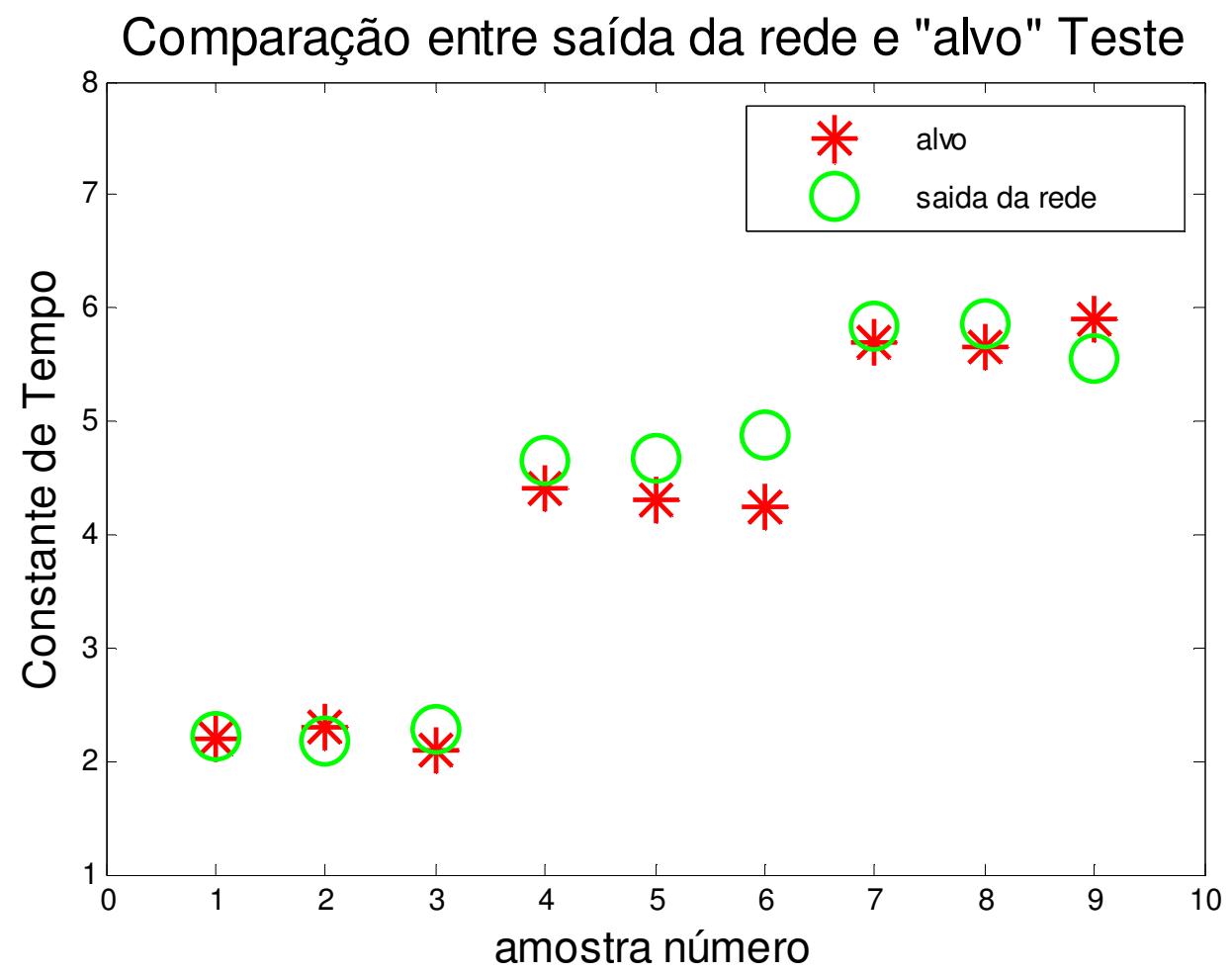

FIGURA 59 - Gráfico de comparação entre saída da rede e alvo (Teste sensor 3). 
TABELA 7 - Resultados dos dados dos três sensores

\begin{tabular}{|c|c|c|c|c|}
\hline & Curva & $\begin{array}{c}\text { Constante de } \\
\text { tempo } \\
\text { Esperado } \\
\text { (Alvo) } \\
\text { (s) }\end{array}$ & $\begin{array}{c}\text { Constante de } \\
\text { tempo RNA } \\
\text { (Saída) } \\
\text { (s) }\end{array}$ & $\begin{array}{c}\text { Erro } \\
\text { Quadrático } \\
\text { (MSE) }\end{array}$ \\
\hline \multirow{21}{*}{ TREINAMENTO } & 1 & 2,20 & 2,2178 & \multirow{21}{*}{$9,2401 \mathrm{e}-4$} \\
\hline & 2 & 2,25 & 2,2508 & \\
\hline & 3 & 2,10 & 2,1088 & \\
\hline & 4 & 2,35 & 2,3507 & \\
\hline & 5 & 2,20 & 2,1886 & \\
\hline & 6 & 2,15 & 2,1702 & \\
\hline & 7 & 2,35 & 2,3559 & \\
\hline & 8 & $4,7,70$ & 4,5688 & \\
\hline & 9 & 5,05 & 5,0688 & \\
\hline & 10 & 4,50 & 4,4978 & \\
\hline & 11 & 4,65 & 4,6464 & \\
\hline & 12 & 4,80 & 4,7972 & \\
\hline & 13 & 4,80 & 4,7714 & \\
\hline & 14 & 4,80 & 4,7949 & \\
\hline & 15 & 5,95 & 5,9528 & \\
\hline & 16 & 6,50 & 6,4978 & \\
\hline & 17 & 6,20 & 6,1967 & \\
\hline & 18 & 6,15 & 6,1469 & \\
\hline & 19 & 5,95 & 5,9502 & \\
\hline & 20 & 5,95 & 5,9497 & \\
\hline & 21 & 5,60 & 5,5965 & \\
\hline & & & & \\
\hline \multirow{9}{*}{ TESTE } & 22 & 2,20 & 2,2220 & \multirow{9}{*}{0,0944} \\
\hline & 23 & 2,30 & 2,1739 & \\
\hline & 24 & 2,10 & 2,2857 & \\
\hline & 25 & 4,40 & 4,6521 & \\
\hline & 26 & 4,30 & 4,6784 & \\
\hline & 27 & 4,25 & 4,8873 & \\
\hline & 28 & $\overline{5,70}$ & 5,8477 & \\
\hline & 29 & 5,65 & 5,8544 & \\
\hline & 30 & 5,90 & 5,5504 & \\
\hline
\end{tabular}

\section{7. - Comparação entre o método tradicional e o método usando RNA}

Para o cálculo da constante de tempo dos sensores do tipo RTD a partir dos testes LCSR são seguidos os seguintes passos: para cada sensor é calculada a curva média dos 10 testes LCSR feitos, e então desta curva média é calculada a constante de tempo. 
Na FIGURA 60 temos a curva média para o sensor 1 e o ajuste desta curva para obtermos os valores de $\tau_{1}$ e $\tau_{2}$ para o cálculo de $\boldsymbol{\tau}$ para o Sensor 1 utilizando a equação 2 . Da mesma forma foi feito com o sensor 2 e o sensor 3 como mostrado na FIGURA 61 e na FIGURA 62 correspondente.

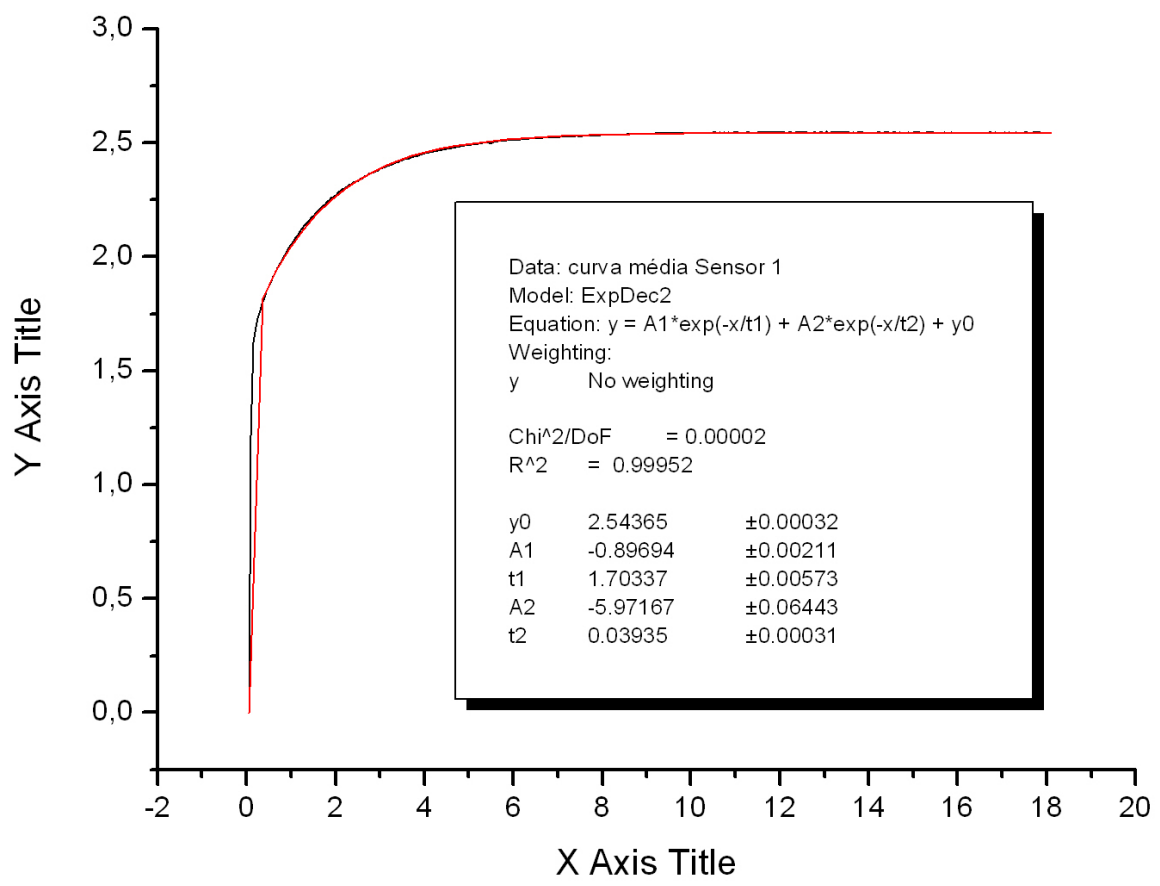

\begin{tabular}{|l|c|c|c|}
\hline Curva & $\boldsymbol{\tau}_{1}$ & $\boldsymbol{\tau}_{2}$ & $\boldsymbol{\tau}$ Sensor 1 \\
$(\mathrm{~s})$ & $(\mathrm{s})$ & $(\mathrm{s})$ \\
\hline média & 1,703 & 0,039 & 1,743 \\
\hline
\end{tabular}

FIGURA 60 - Cálculo da constante de tempo Sensor 1. 


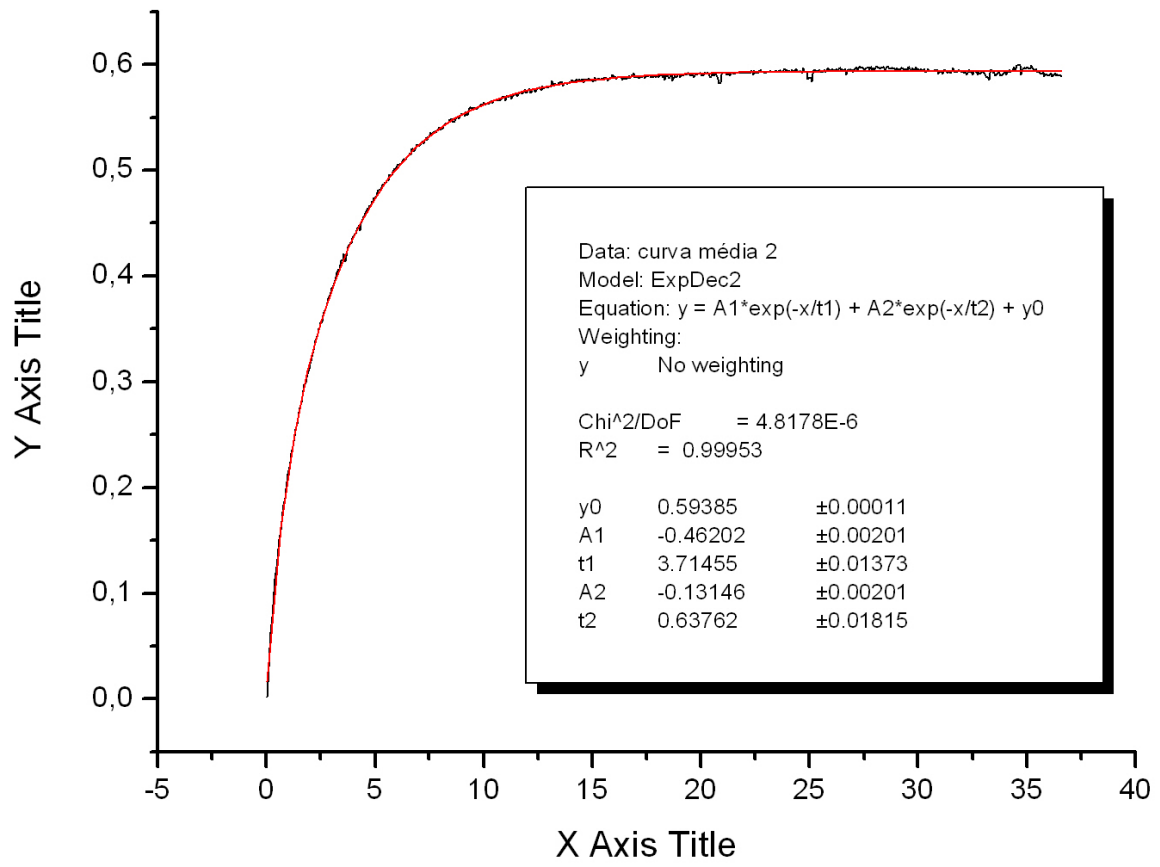

\begin{tabular}{|l|l|c|c|}
\hline Curva & $\boldsymbol{\tau}_{1}$ & $\boldsymbol{\tau}_{2}$ & \multicolumn{1}{|c|}{$\begin{array}{c}\text { Sensor } 2 \\
(\mathrm{~s})\end{array}$} \\
\hline média & 3,715 & 0,638 & 4,414 \\
\hline
\end{tabular}

FIGURA 61 - Cálculo da constante de tempo Sensor 2. 


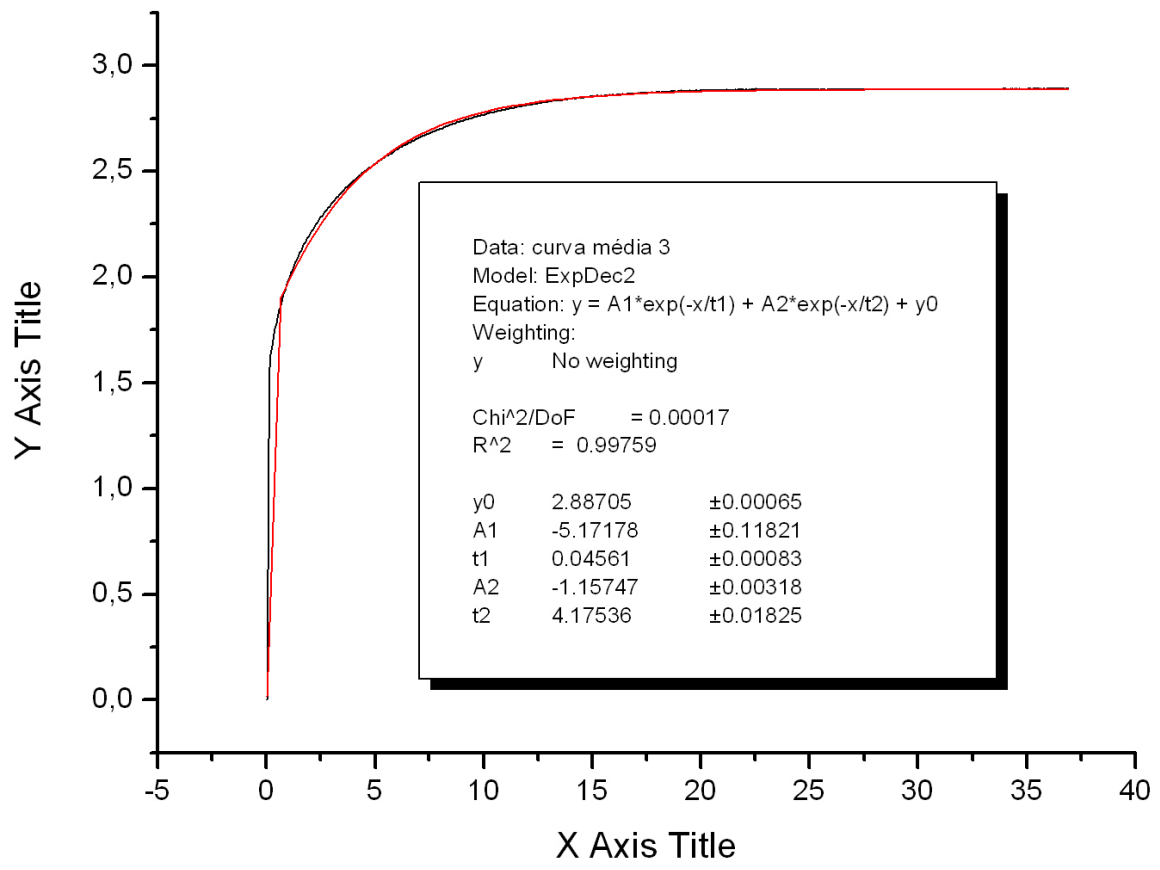

\begin{tabular}{|l|c|c|c|}
\hline Curva & $\begin{array}{c}\boldsymbol{\tau} 1 \\
(\mathrm{~s})\end{array}$ & $\begin{array}{c}\boldsymbol{\tau} 2 \\
(\mathrm{~s})\end{array}$ & $\begin{array}{c}\boldsymbol{\tau} \text { Sensor 3 } \\
(\mathrm{s})\end{array}$ \\
\hline média & 4,175 & 0,046 & 4,221 \\
\hline
\end{tabular}

FIGURA 62 - Cálculo da constante de tempo Sensor 3.

Para comparar estes valores com aqueles valores de constante de tempo estimados pela RNA, foi calculada a média dos valores estimados para cada sensor. Na TABELA 8 tem-se a comparação entre os valores obtidos pelo método de LCSR e RNA com os valores de constante de tempo obtidos nos Testes de Imersão Rápida.

TABELA 8 - Comparação entre LCSR e RNA.

\begin{tabular}{|l|r|r|r|}
\hline & $\begin{array}{c}\text { sensor 1 } \\
(\mathrm{s})\end{array}$ & $\begin{array}{c}\text { sensor 2 } \\
\text { (s) }\end{array}$ & $\begin{array}{c}\text { sensor 3 } \\
\text { (s) }\end{array}$ \\
\hline LCSR & 1,743 & 4,414 & 4,221 \\
\hline RNA & 2,227 & 4,739 & 5,751 \\
\hline Imersão & 2,220 & 4,620 & 5,950 \\
\hline & & & \\
\hline erro LCSR \% & 21 & 4,5 & 29 \\
\hline erro RNA \% & 0,31 & 2,57 & 3,34 \\
\hline
\end{tabular}




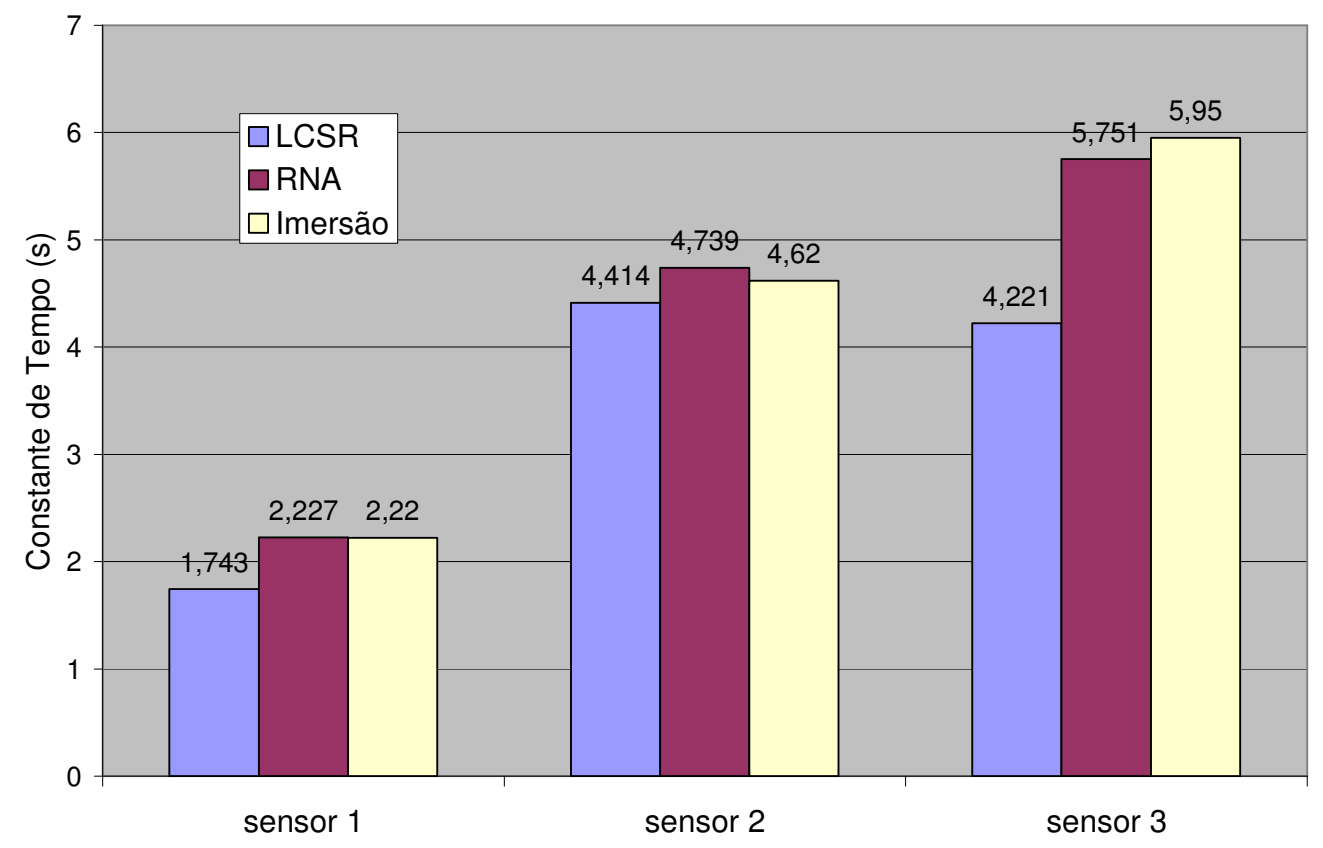

FIGURA 63 - Comparação entre as metodologias convencionais e RNAs. 


\section{7. - CONCLUSÕES}

Os resultados obtidos mostram que é possível a utilização de RNAs para determinar o tempo de resposta de sensores de temperatura do tipo RTD. Os dados dos testes LCSR foram utilizados como entrada da RNA e os dados dos testes de Imersão Rápida foram utilizados como saída da RNA. As redes foram treinadas admitindo-se um erro máximo de 0,001 entre a saída da rede e o alvo.

A metodologia foi aplicada inicialmente a dados teóricos, simulando o resultado de testes LCSR em 10 diferentes sensores. Os valores de constante de tempo obtidos apresentaram um erro de $0,74 \%$ em relação ao valor esperado. Esse valor de erro corresponde a um erro quadrático médio de aproximadamente $510^{-5}$.

Dados experimentais de três diferentes sensores foram utilizados para elaborar novas RNAs. Para cada sensor foi modelada uma rede, obtendo-se valores de erros quadráticos médios de 0,003 para o sensor 1, 0,4298 para o sensor 2 e 0,1151 para o sensor 3. Finalmente foi modelada uma rede com dados dos 3 sensores, obtendo-se um valor de erro quadrático médio de 0,0944 .

Os valores de constante de tempo estimados por esta última RNA foram comparados com os valores obtidos no Teste de Imersão Rápida, obtendo-se erros de $0,31 \%$ para o sensor $1,2,57 \%$ para o sensor 2 e $3,34 \%$ para o sensor 3 .

A estimativa da constante de tempo utilizando-se RNAs foi comparada com o método tradicional, onde as curvas resultantes dos testes LCSR são ajustadas de modo a determinar os coeficientes exponenciais a partir dos quais é calculado o valor da constante de tempo. Estes valores produziram erros de $21 \%$ para o sensor 1, 4,5\% para o sensor $2 \mathrm{e}$ $29 \%$ para o sensor 3 , ou seja, uma média de $18 \%$ de erro.

A utilização de RNAs para determinar o tempo de resposta de sensores de temperatura do tipo RTD mostrou-se uma metodologia eficaz, resultando em erros de no máximo 3,34\%, valor muito inferior àquele obtido através da metodologia tradicional. 


\section{1 - Considerações Finais e Recomendações para trabalhos futuros}

Os excelentes resultados obtidos neste trabalho são devidos ao fato de termos o valor real da constante de tempo do sensor. Este valor foi obtido diretamente do Teste de Imersão Rápida realizado em laboratório. Os testes LCSR feitos nos 3 sensores também foram realizados no laboratório, nas mesmas condições de temperatura e vazão do banho térmico. Para que esta metodologia possa ser aplicada na determinação da constante de tempo dos RTDs instalados nas usinas nucleares, é necessário criar um banco de dados com valores de constante de tempo dos sensores para diferentes condições de operação.

Novas RNAs poderão ser implementadas utilizando um maior número de sensores de temperatura do tipo RTD. Além de testes em laboratório, poderão ser incluídos resultados de testes realizados em sensores instalados em uma central nuclear. Os resultados de medidas realizadas ao longo dos anos podem ser utilizados para compor um banco de dados confiável. 


\section{REFERÊNCIAS BIBLIOGRÁFICAS}

1 ABO-SHOSHA A., et. al.Using Neural Network in fault diagnosis of nuclear power reactors.1997. Disponível em:

<http://www.icgst.com/biography/cse/robotics/Aboshosha/ICECS97.pdf> Acesso em: 03 setembro 2010.

2 AMS. Analysis and Measurements Corporation. Disponível em: <http://www.amscorp.com/cms/\%20RTD/19.html >Acesso em: 03 setembro 2010.

3 BERNIERI, A et al. A Neural Network approach to instrument fault detection and isolation. Instrument and Measurement Technology Conference, v. 1, p. 139-144, 1994.

4 BRAGA, A. P.; LUDERMIR, T. B.; CARVALHO, A. Redes Neurais Artificiais Teoria e Aplicações. Livros Técnicos e Científicos, São Paulo, 1999.

5 BUENO, E. I. Utilização de Redes Neurais Artificiais na Monitoração e Detecção de Falhas em sensores do Reator IEA-R1.Tese (Mestrado), IPEN, São Paulo, 2006

6 GONÇALVES, I. M. P., Determinação do Tempo de Resposta de Sensores de Temperatura do Tipo RTD através de medidas in situ. Tese (Mestrado), IPEN, São Paulo, 1985.

7 GONÇALVES, I. M. P., TING, D. K. S. Medida do Tempo de Resposta de Sensores de Temperatura e Pressão da Usina Nuclear de Angra I Utilizando a Técnica de Análise de Ruído. - IPEN 2000

8 GONÇALVES, I.M.P., PERILLO, SRP., Resultado dos Testes de Tempo de Resposta dos Sensores de Temperatura de Angra-I - projeto número: PSE.REI.FURNAS.006 - Relatório Técnico RELT.003.R00 - IPEN 1997

9 GONÇALVES, I.M.P., SANTOS, R.C., MESQUITA, R.N., Medida dos Tempos de Resposta de Sensores do Sistema de Proteção do Reator da Unidade I da CNAAA - PT 207 - Relatório Técnico RELT 00100 - IPEN 2007.

10 HASHEMIAN, H.M., KERLIN, T.W., and Petersen, K.M., "In-Situ Response Time Testing of Temperature and Pressure Sensors. " Presented at IEEE Winter Power Meeting, New York, NY (February 1986).

11 HASHEMIAN, H.M., Maintenance of Process Instrumentation in Nuclear Power Plants, Springer-Verlag Berlin Heidelberg 2006.

12 HAYKIN, S. Neural Networks - A Comprehensive Foundation. Prentice Hall, 1999.

13 HEBB, D. O. The Organization of behavior: a neuropsychological theory. New York: Wiley, 1949. 
14 KERLIN, T. W.; MILLER, L. F. ; HASHEMIAN, H. M. In-Situ Response Time Testing of Platinum Resistance Thermometers, ISA Transactions, v. 17, n. 4, 1978.

15 KEYVAN, S., DURG, A., NAGARAJ, J. Application of artificial neural networks for the development of a signal monitoring system. Expert Systems, v. 14, n. 2, Maio 1997.

16 KOVÁCS, Z. L., "Redes Neurais Artificiais - Fundamentos e Aplicações", Edição Acadêmica, São Paulo, 1996.

17 LIMA, P. R., Estudo da Metodologia de Análise de Séries Temporais Aplicada a Monitoração do Tempo de Resposta dos Instrumentos Ligados ao sistema de Proteção de Reatores Nucleares. Tese Mestrado, IPEN, São Paulo, 1995.

18 MAKI, Y., LOPARO, K. A. A Neural Network approach to fault detection and diagnosis in industrial processes. IEEE Transaction on control system technology, v. 5, n. 6, Novembro 1997.

19 MATLAB Version 5, The MATH WORKS Inc, MA, USA 1997.

20 MC CULLOCH, W.S., PITTS, W. A logical calculus of ideas immanent in nervous activity, Bulletin of Mathematical Biophysics, v.5, p.115-113, 1943.

21 MECATRÔNICA ATUAL - Automação Industrial de Processos e Manufatura São Paulo- Editora Saber LTDA - 2010 - http://www.mecatronicaatual.com.br/

22 MORLEY, R. E. New in Situ Sensor Modeling Approach to Measurement Validation, 2003. Disponível em: <http://pubs.acs.org/doi/full/10.1021/ie0209834>. Acesso em: 03 setembro 2010.

23 OLIVEIRA, M. A. A. Algoritmos para Auto-Ajuste de Sensores Utilizando Redes Neurais, 2009. Disponível em: $<$ http://limcserver.dee.ufcg.edu.br/semetro/www/pdf/52358_1.pdf > Acesso em: 03 setembro 2010.

24 ORIGIN LAB publishes graphing and data analysis software.- 2007

25 PERILLO, S.R.P., GONÇALVES, IMP., Resultado dos Testes de Tempo de Resposta dos Transdutores de Pressão de Angra-I - projeto número: PSE.REI.FURNAS.006 - Relatório Técnico RELT.002.R00 - IPEN 1996.

26 PERIODIC, testing of electric power and protection system. Washington, D. C., US Nuclear Regulatory commission, Nov. 1977 (Regulatory Guide 1.118).

27 PERIODIC, testing of electric power and protection system. Washington, D. C., US Nuclear Regulatory commission, Revision April 1995 (Regulatory Guide 1.118).

28 PSI 5886 - Princípios de Neurocomputação - Pós graduação - Escola Politécnica da USP - Prof. Emílio Del Moral Hernandez - 2009 
29 ROSSI, R. H. P. S. Utilização de Redes Neurais na monitoração da potência do Reator IEA-R1. Dissertação (mestrado), Instituto de Pesquisas Energéticas e Nucleares - IPEN, 151 p., São Paulo, 2001.

30 SANTOS, R.C., GONÇALVES, I.M.P., MESQUITA, R.N., Medida dos Tempos de Resposta de Sensores do Sistema de Proteção do Reator da Unidade I da CNAAA - PT 138 - Relatório Técnico RELT 00101 - IPEN 2006.

31 SEKER, S. et al. Artificial neural networks for dynamic monitoring of simulatedoperating parameter of high temperature gas cooled engineering teste reactor (HTTR). Annals of Nuclear Energey, v. 30, p. 1777-1791, 2003.

32 SELIGER, B. K., FRANK, P. M. Fault Detection and Isolation in Technical Processes with Neural Networks. Proceeding of the $34^{\text {th }}$ Conference on Decision \& Control, New Orleans, LA, Dezembro 1995.

33 SIMANI, S.; FANTUZZI, C. Fault diagnosis in power plant using neural networks. Information Sciences, v. 117, p. 125-136, 2000.

34 SORSA, T., KOIVO, N. H. Neural Networks in process fault diagnosis. IEEE Transactions on systems, Man and Cybernetics, v. 21, n. 4, Julho/Agosto 1991.

35 TORRES Jr. Previsão de Séries Temporais de Falhas em Manutenção Industrial Usando Redes Neurais, 2005. Disponível em:

<http://www.uff.br/engevista/seer/index.php/engevista/article/viewArticle/163> Acesso em: 03 setembro 2010

36 TORRES, W. M. Desenvolvimento de uma Técnica de Medida de Nível em Vasos de Pressão Utilizando Sondas Térmicas e Redes Neurais Artificiais, 2008. Disponível em: <http://pelicano.ipen.br/PosG30> Acesso em: 03 setembro 2010.

37 WEED INSTRUMENT COMPANY, INC. D/B/A ULTRA ELECTRONICS, Nuclear Sensors \& Process Instrumentation. 707 Jeffrey Way Round Rock, TX 78665-2408USA 